UNIVERSIDADE DE SÃO PAULO

FACULDADE DE ECONOMIA, ADMINISTRAÇÃO E CONTABILIDADE DE RIBEIRÃO PRETO

DEPARTAMENTO DE ADMINISTRAÇÃO

PROGRAMA DE PÓS-GRADUAÇÃO EM ADMINISTRAÇÃO DE ORGANIZAÇÕES

TÁSSIA GERBASI

Uma proposta de método para gestão estratégica de cadeias produtivas em um recorte estadual ORIENTADOR: PROF. DR. MARCOS FAVA NEVES

RIBEIRÃO PRETO

2014 
Prof. Dr. João Grandino Rodas

Reitor da Universidade de São Paulo

Prof. Dr. Sigismundo Bialoskorski Neto

Diretor da Faculdade de Economia, Administração e Contabilidade de Ribeirão Preto

Profa. Dra. Sonia Valle Walter Borges de Oliveira

Chefe do Departamento de Administração 


\section{TÁSSIA GERBASI}

Uma proposta de método para gestão estratégica de cadeias produtivas em um recorte estadual

Dissertação apresentada ao Programa de Pós-Graduação em Administração de Organizações da Faculdade de Economia, Administração e Contabilidade de Ribeirão Preto da Universidade de São Paulo, para obtenção do título de Mestre em Ciências.

"Versão corrigida. A original encontra-se disponível no Serviço de Pós-Graduação da FEA-RP/USP".

ORIENTADOR: PROF. DR. MARCOS FAVA NEVES

RIBEIRÃO PRETO

2014 
Autorizo a reprodução e divulgação total ou parcial deste trabalho, por qualquer meio convencional ou eletrônico, para fins de estudo e pesquisa, desde que citada a fonte.

Catalogação da Publicação

Nome da Biblioteca que realizou a catalogação

\section{Gerbasi, Tássia}

Uma proposta de método para gestão estratégica de cadeias produtivas em um recorte estadual. Ribeirão Preto, 2014.

146 p. : il. ; $30 \mathrm{~cm}$

Dissertação de Mestrado, apresentada à Faculdade de Economia, Administração e Contabilidade de Ribeirão Preto/USP. Área de concentração: Administração de Organizações.

Orientador: Fava Neves, Marcos.

1. Gestão Estratégica. 2. Cadeia Produtiva 3. Estados. 4. Estudo de caso. 


\section{FOLHA DE APROVAÇÃO}

Nome: GERBASI, Tássia

Título: Uma proposta de método para gestão estratégica de cadeias produtivas em um recorte estadual

Dissertação apresentada ao Programa de PósGraduação em Administração de Organizações da Faculdade de Economia, Administração e Contabilidade de Ribeirão Preto da Universidade de São Paulo, para obtenção do título de Mestre em Ciências.

Aprovada em:

Banca Examinadora

Prof. Dr. Marcos Fava Neves Julgamento:

Prof. Dr. Dante Pinheiro Martinelli Julgamento:

Profa. Dra. Maria Inez Espagnoli Geraldo Martins Julgamento:
Instituição: FEARP/USP

Assinatura:

Instituição: FEARP/USP

Assinatura:

Instituição: FCAV/UNESP Assinatura: 
Dedico meu trabalho à toda a minha família, em especial ao meu pai Dalton Moretti Gerbasi e à minha mãe Silvia Helena Brendolan Gerbasi, que me educaram nos mais valiosos aspectos da vida e além de pais, são meus grandes amigos e conselheiros.

À minha irmã, Tábata Gerbasi por estar sempre ao meu lado sendo minha eterna "professora".

À minha avó Otilia Pelicano Brendolan por ser a maior entusiasta de todas as minhas atividades e confiar na minha competência.

Ao meu namorado Diego Furlan, por me incentivar e acreditar em tudo que faço e ser um grande exemplo profissional e principalmente pessoal para mim, sendo sempre um companheiro perfeito.

Ao meu parceiro e grande amigo Rafael Kalaki, que desde o início, não só dividiu comigo as tarefas acadêmicas, mas também auxiliou e se mostrou disponível em todas as ocasiões. 


\section{AGRADECIMENTOS}

Pelos anos de conhecimento e maturidade adquiridos nesta instituição, a muitos tenho que agradecer:

- Agradeço inicialmente ao grande Mestre Prof. Dr. Marcos Fava Neves, que confiou na minha competência e muito além de auxiliar no meu trabalho acadêmico, se tornou um exemplo pessoal e profissional para mim.

- Aos Professores Dr. Dante Pinheiro Martinelli e Dra. Maria Inez Espagnoli Geraldo Martins pelas excelentes contribuições ao meu trabalho e consequente auxílio no meu desenvolvimento acadêmico.

- A equipe da FIEG nas figuras de Igor Montenegro Celestino e Sulamita de Aquino Porto, por todo apoio durante a pesquisa e sábias contribuições ao método final.

- Aos profissionais com ampla experiência de mercado das empresas que contribuíram com a execução do trabalho, fornecendo ricas informações e percepções acerca do tema.

- Aos queridos colegas e amigos da Markestrat, pelo auxílio e apoio durante toda a caminhada em especial Mairun Junqueira Alves Pinto, Vinícius Gustavo Trombin, Maria Stella Melo Saab e Rafael Bordonal Kalaki, por sempre fornecerem excelentes conselhos.

- Á CAPES pelo auxílio financeiro para realização do trabalho.

- A todos os funcionários da Faculdade de Economia, Administração e Contabilidade da USP de Ribeirão Preto, em especial Érika Costa, Vânia e Matheus pelo auxílio e prontidão em todos os serviços prestados.

- A todos os meus amigos que sempre foram uma importante fonte de desenvolvimento pessoal e profissional, em especial à minha companheira Amanda Bellodi Gerbasi por compartilhar todos os momentos vividos desde o início dessa jornada. 


\section{RESUMO}

GERBASI, T. Uma proposta de método para gestão estratégica de cadeias produtivas em um recorte estadual. 2014. 144 f. (Mestrado) - Faculdade de Economia, Administração e Contabilidade de Ribeirão Preto, Universidade de São Paulo, Ribeirão Preto, 2014.

O Brasil é um país movido pelo agronegócio. Dados da sua balança comercial indicam que o setor agro contribuiu com US\$ 82,9 bilhões no ano de 2013 (BRASIL, 2014), no entanto, apesar de sua grandeza, no Brasil, muito ainda deve ser estudado e melhorado. Tendo em vista as ameaças que afetam o agronegócio brasileiro e sua grande importância econômica é necessário trabalhar constantemente na melhoria da sua competitividade, cenário onde a Gestão Estratégica surge como importante ferramenta. Um método de Gestão Estratégica específico para Sistemas Agroindustriais foi proposto por Neves (2008), porém não possui especificidades relacionadas à abrangência geográfica. Visto que os estados podem ser caracterizados como uma "união", contando com características específicas e concorrentes bem definidos, seus direcionamentos e ações devem ser tomados unificadamente, sendo justificável que seus sistemas agroindustriais sejam organizados conjuntamente, por meio de um planejamento próprio. O presente trabalho busca responder à seguinte pergunta: Dentro das suas especificidades, é possível gerir estrategicamente os sistemas agroindustriais de um estado? Qual pode ser o método para tal? Para tanto, lança mão de uma pesquisa exploratória qualitativa que analisa um estudo de casos múltiplos onde o método GESis proposto por Neves (2008), com algumas adaptações, foi aplicado em cinco cadeias produtivas do estado de Goiás. Os estudos de caso contaram com entrevistas em profundidade com interlocutores das cadeias estudadas e, após finalizados, foram conduzidas entrevistas com aqueles que participaram da elaboração e aplicação do plano finalizado no estado. Como resultado, foi proposto um método de gestão estratégica para cadeias produtivas em estados que conta com 13 etapas. O trabalho identificou que existe uma grande lacuna no setor agropecuário brasileiro quando se trata de ações coletivas sendo que o sucesso da implantação do método é altamente dependente da ação conjunta de seu setor alvo.

Palavras-chave: Gestão Estratégica. Cadeia Produtiva. Estados. Estudo de Caso 


\begin{abstract}
GERBASI, T. A proposal of productive chain strategic management in states. 2014. 144 p. (Master) - Faculty of Economics, Business and Accounting of Ribeirão Preto, University of São Paulo, Ribeirão Preto, 2014.

Abstract: Brazil is a country driven by agribusiness. Its trade balance data indicates that the agriculture sector contributed with US\$ 82,9 billion in 2013 (BRASIL, 2014), however, in spite of his greatness, in Brazil, much remains to be studied and improved. In view of the threats affecting the sector and its economic importance, its necessary to work constantly on improving its competitiveness, scenario where the Strategic Management emerged as an important tool. A specific method for Agribusiness Strategic Management Systems was proposed by Neves (2008), but does not include specifics related to the geographic scope. Since states can be characterized as a "union", with specific characteristics and well defined competitors, their direction and actions must be taken together, being justified jointly actions for organization of their agribusiness systems through a proper planning. This paper seeks to answer the following question: Within its specifics, is it possible to manage strategically the agribusiness systems of a state? What can be the method for it? To do so, the study makes use of a qualitative exploratory study that analyzes a multiple case study where the method proposed by Neves GESis (2008), with some adaptations, was applied in five chains in the state of Goiás. The study cases used in-depth interviews with representatives of the studied chains and, after finalized, were conducted interviews with the ones who participated in the plan development and implementation in the state. As a result, it was proposed a method of strategic management for productive chains in states that has 13 steps. The study identified that there is a large gap in the Brazilian agricultural sector when it comes to collective action and the successful implementation of the method is highly dependent on the target sector joint actions.
\end{abstract}

Keywords: Strategic Management, Agribusiness System, States, Case Study 


\section{LISTA DE FIGURAS}

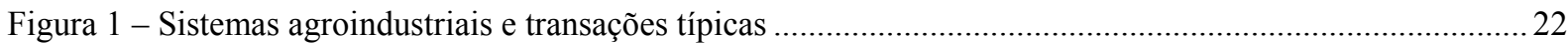

Figura 2 - Árvore de decisão para escolhas estratégicas em um ambiente de incerteza. ........................................ 34

Figura 3 - Planejamento estratégico de cidades - organização inicial................................................................. 44

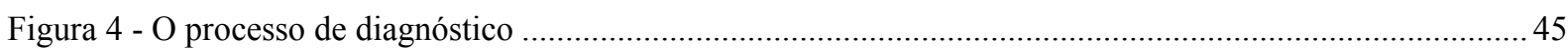

Figura 5- Método proposto para planejamento e gestão estratégica de sistemas agroindustriais. ..........................56

Figura 6 - Método utilizado para caracterizar e quantificar sistemas agroindustriais.............................................57

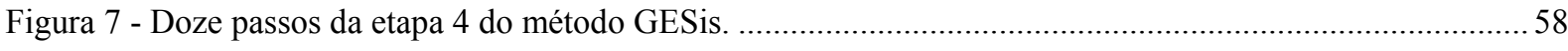

Figura 8 - Método GESis - Planejamento e Gestão Estratégica de Sistemas Agroindustriais. .............................. 62

Figura 9 - Quatorze passos para a gestão estratégica das cadeias produtivas de Goiás........................................... 63

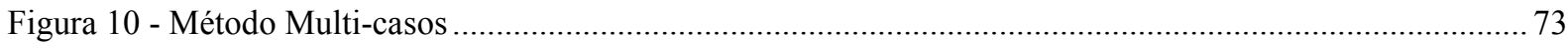

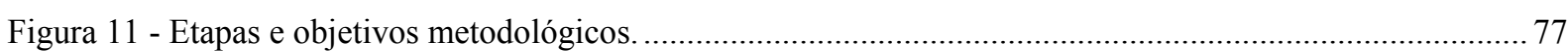

Figura 12 - Sequência de ações executadas para a aplicação do método GESis adaptado no estado de Goiás. ....78

Figura 13 - Quadro de consolidação das ferramentas PEST e Cinco Forças de Porter ......................................... 125

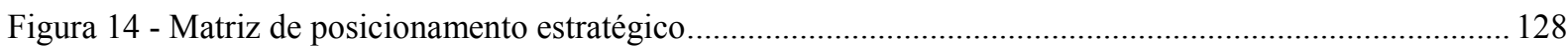

Figura 15 - Plano de Gestão Estratégica de Cadeias Produtivas para um Recorte Estadual................................ 131 


\section{LISTA DE QUADROS}

Quadro 1 - Métodos de planejamento e gestão estratégica.

Quadro 2- Métodos de planejamento e gestão estratégica

Quadro 3 - Planejamento e gestão estratégica para sistemas agroindustriais - sequencia detalhada dos passos propostos

Quadro 4 - Principais diferenças entre o método GESis original e o método modificado..................... 68

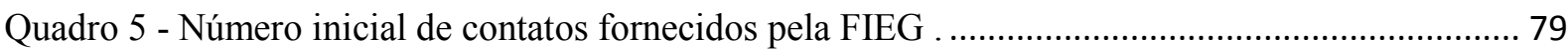

Quadro 6 - Número e origem dos 35 entrevistados nos estudos de caso em Goiás. .............................. 80

Quadro 7 - Número e origem dos interlocutores presentes no workshop. ............................................ 81

Quadro 8 - Principais problemas encontrados na cadeia de carne bovina do estado de Goiás. ............ 86

Quadro 9 - Planos vetores estratégicos, objetivos e ações estratégicas propostas para a cadeia de carne

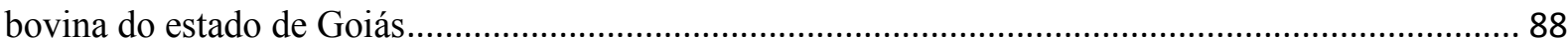

Quadro 10 - Principais problemas encontrados na cadeia de aves e suínos do estado de Goiás........... 92

Quadro 11 - Planos vetores estratégicos, objetivos e ações estratégicas propostas para as cadeias de

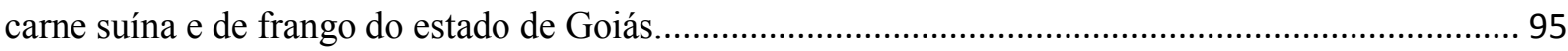

Quadro 12 - Principais problemas encontrados na cadeia de lácteos do estado de Goiás................... 100 Quadro 13 - Planos vetores estratégicos, objetivos e ações estratégicas propostas para a cadeia de leite

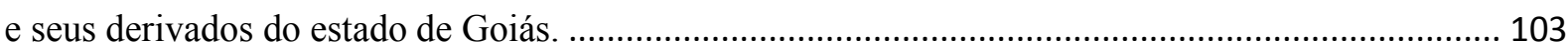

Quadro 14 - Principais problemas encontrados na cadeia de soja e milho do estado de Goiás. ......... 108 Quadro 15 - Planos vetores estratégicos, objetivos e ações estratégicas propostas para as cadeias de

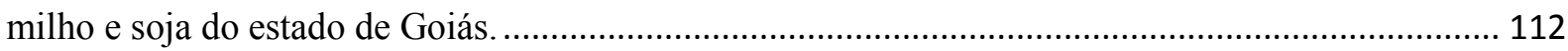

Quadro 16 - Principais problemas encontrados na cadeia sucroenergética do estado de Goiás........... 117

Quadro 17 - Planos vetores estratégicos, objetivos e ações estratégicas propostas para o setor sucroenergético do estado de Goiás. 


\section{LISTA DE TABELAS}

Tabela 1 - Comparação de rebanho, produção e produtividade dos principais estados produtores de carne bovina do Brasil..

Tabela 2 - Relação de estabelecimentos de apoio à produção de aves e suínos no estado de Goiás..... 91

Tabela 3 - Exportações e importações brasileiras de leite e derivados em 2012

Tabela 4 - Produção e produtividade dos principais estados produtores de leite do Brasil em 2012 .... 97

Tabela 5 - Remuneração por vaca ordenhada no ano de 2012

Tabela 6 - Evolução da produtividade da soja nos últimos 32 anos...

Tabela 7 - Comparação dos principais estados brasileiros produtores de grãos 106

Tabela 8 - Comparação Brasil/Goiás das taxas de produtividade da soja e milho. 107

Tabela 9 - Exportações do complexo soja de Goiás no ano de 2012. 108 


\section{LISTA DE GRÁFICOS}

Gráfico 1 - Produção e industrialização de leite por estado no ano de 2012....................................... 98

Gráfico 2 - Custo de produção efetivo, preço da terra e preço pago ao produtor de leite em 2013 ..... 99 


\section{LISTA DE SIGLAS}

AGF - Aquisição do Governo Federal

ASSOCON - Associação Nacional dos Confinadores

BRICs - Brasil, Rússia, Índia e China

CSA - Commodity System Approach

ECT - Economia dos Custos de Transação

EMBRAPA - Empresa Brasileira de Pesquisa Agropecuária

EUA - Estados Unidos da América

FAEG - Federação da Agricultura e Pecuária de Goiás

FECOMÉRCIO - Federação do Comércio

FIEG - Federação das Indústrias do Estado de Goiás

GCC - Global Commodity Chain

GVC - Global Value Chain

MODERAGRO - Programa de Modernização da Agricultura e Conservação dos Recursos

Naturais

MODERINFRA - Política de Apoio à Armazenagem e à Irrigação

OCDE - Organização das Nações Unidas para Alimentação e Agricultura

ORPANA - Associação dos Plantadores de Cana da Região Centro-Sul do Páis

P.E. - Planejamento Estratégico

PEST - Político-legais, economico-naturais, socio-culturais e tecnológicos

PRODECOOP- Política de Apoio às Cooperativas de Produção Agropecuária

PRONAMP - Política de Apoio ao Médio Produtor Rural

PSR - Programa de Subvenção ao Seguro Rural

PUC - Pontifícia Universidade Católica

$\mathrm{SAG}$ - Sistema Agroindustrial 
SEAGRO - Secretaria de Estado de Agricultura, Pecuária e Irrigação

SEBRAE - Serviço Brasileiro de Apoio às Micro e Pequenas Empresas

SECTEC - Secretaria de Estado de Ciência e Tecnologia

SEGPLAN - Secretaria de Estado de Gestão e Planejamento

SEINFRA - Secretaria de Estado de Infraestrutura

SEMARH - Secretaria do Meio Ambiente e dos Recursos Hidricos

SIC - Serviço de Informação da Carne

SIFAEG - Sindicato da Indústria de Fabricação de Etanol do Estado de Goiás

SINDICARNES - Sindicato das Indústrias de Carnes e Derivados no Estado de Goiás

SINDICURTUME - Sindicato das Indústrias de Curtume e Correlatos do estado de Goiás

SINDILEITE - Sindicato da Indústria de Laticínios e Produtos Derivados

SWOT - Strength, Weakness, Opportunities, Threats

UFG - Universidade Federal de Goiás

UHT - Ultra High Temperature

ÚNICA - União das Indústrias de Cana-de-Açúcar

USDA - United States Department of Agriculture 


\section{Sumário}

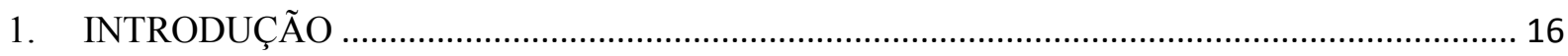

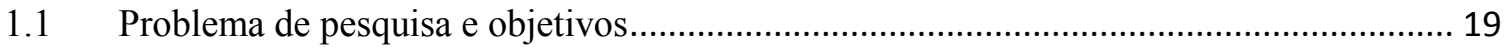

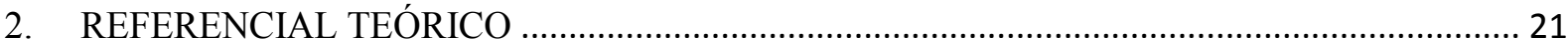

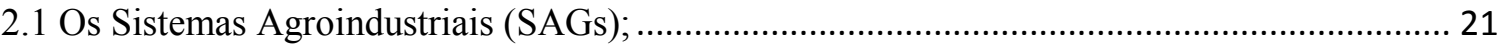

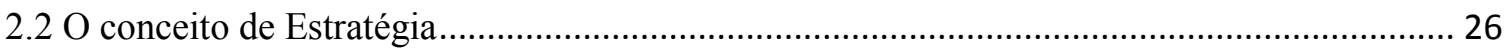

2.3 A criação da vantagem competitiva e a competitividade ......................................................... 28

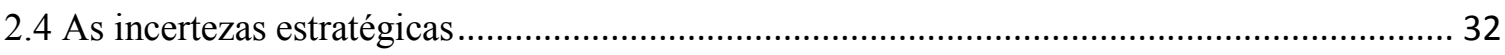

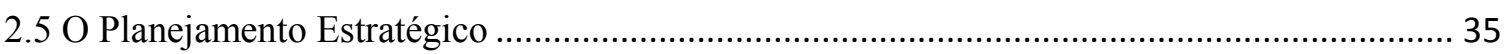

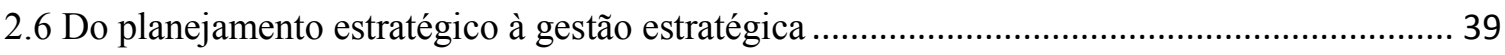

2.7 Métodos de planejamento estratégico, planejamento de marketing e gestão estratégica ......... 40

2.8 O método GESis de planejamento e gestão estratégica de cadeias produtivas ........................ 56

2.9 O método GESis adaptado e suas principais alterações ........................................................ 61

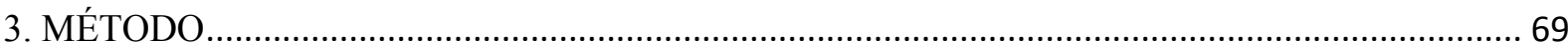

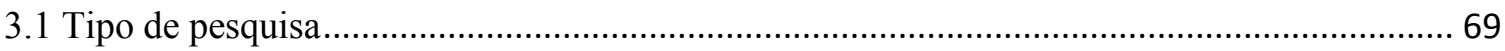

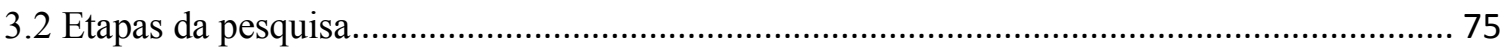

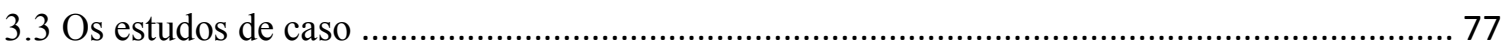

4. APRESENTAÇÃO E ANÁLISE DOS CASOS .......................................................................... 82

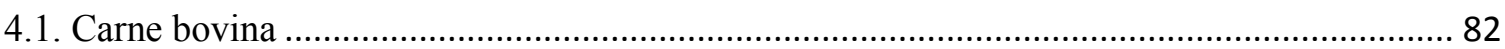

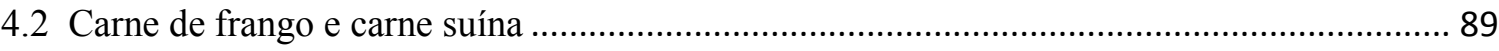

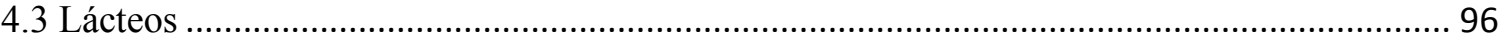

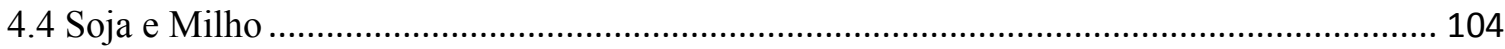

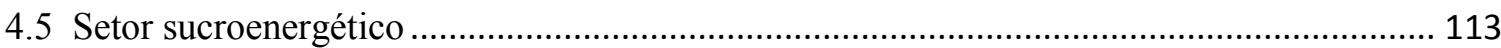

5. CONTRIBUIÇÕES DOS AGENTES ENVOLVIDOS DIRETAMENTE NA ELABORAÇÃO DO PLANO ESTRATÉGICO PARA O NOVO MÉTODO …..................................................... 121

6. O MÉTODO DE GESTÃO ESTRATÉGICA DE CADEIAS PRODUTIVAS PARA UM

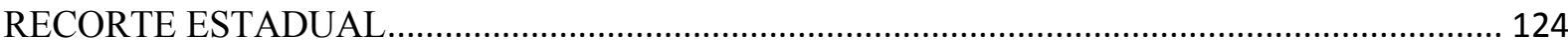

6.1. ETAPA 1: Sensibilização para execução do plano ……………………………..................... 124

6.2. ETAPA 2: Sensibilização dos agentes pertencentes à cadeia alvo do estudo ....................... 124

6.3. ETAPA 3: Levantamento e análise do ambiente externo.................................................... 125

6.4. ETAPA 4: Levantamento e análise do ambiente interno .................................................... 126

6.5. ETAPA 5: Situação interna na visão de especialistas e agentes do setor .............................. 126

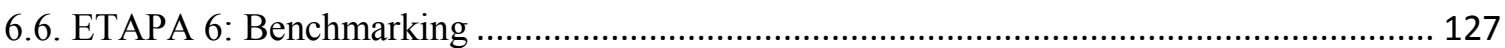

6.7. ETAPA 7: Determinação do posicionamento estratégico da cadeia ..................................... 127 
6.8. ETAPA 8: Proposição de missão e visão para a cadeia

6.9. ETAPA 9: Identificação dos vetores estratégicos a serem trabalhados e proposição de objetivos e ações para cada um

6.10. ETAPA 10: Workshop com especialistas e agentes da cadeia alvo no estado para validação do plano de gestão estratégica para o estado

6.11. ETAPA 11: Apresentação do plano e determinação de responsáveis e prazos para sua execução

6.12. ETAPA 12: Divulgação do plano estratégico 130

6.13. ETAPA 13: Controle 131

7. CONSIDERAÇÕES FINAIS, IMPLICAÇÕES GERENCIAIS, LIMITAÇÕES E SUGESTÕES

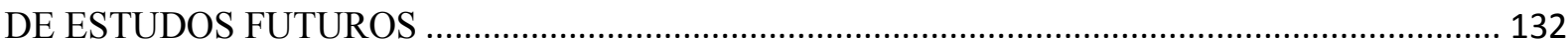

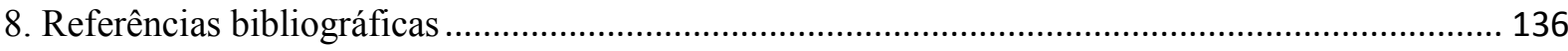

APÊNDICE A: ROTEIRO DE ENTREVISTA (contribuições ao método) ……................................. 143

APÊNDICE B: ROTEIRO DE ENTREVISTA (interlocutores das cadeias) ..................................... 144

APENDICE C: CRONOGRAMA DE EXECUÇÃO ……………................................................ 146 


\section{INTRODUÇÃ̃O}

A indústria global de alimentos e o agronegócio mundial estão imersos em um contexto muito dinâmico, repleto de constantes mudanças.

Em se tratando de consumo, as necessidades mundiais de alimentos elevam-se bem como o aumento da renda, o crescimento populacional e a migração da população rural para áreas urbanas.

O crescimento populacional com o maior aporte de renda em países como a China e a Índia, vem fazendo com que a demanda por uma dieta mais rica em carnes e alimentos provenientes do leite aumente consideravelmente. Para tanto, as cadeias de grãos para ração animal e dos combustíveis também devem ser altamente eficientes. Por outro lado, países como aqueles pertencentes à União Europeia, possuem uma população estável que vem mudando seus hábitos de consumo, buscando produtos mais saudáveis e ambientalmente corretos.

Surge então uma restrição a todo este crescimento: de onde serão tirados os fatores de produção necessários para o suprimento dessa crescente demanda? Entende-se como fatores de produção aqueles recursos essenciais para a prática de determinada atividade. $\mathrm{Na}$ agricultura, pode-se caracterizar como fatores de produção as terras, água, clima, insumos, tecnologia, mão de obra, entre outros. O sucesso de uma produção agrícola depende inicialmente da disponibilidade desses fatores e de seu correto uso.

Com o aumento dos consumidores no mercado, demandando maior quantidade de alimentos e energia, a disputa pelos fatores de produção é cada vez maior e a importância dos países detentores desses fatores é crescente, cenário no qual o Brasil se insere.

O Brasil é um país movido pelo agronegócio, figurando entre os principais fornecedores de alimentos do mundo. Essa afirmação é evidenciada pelos números de sua balança comercial. No ano de 2013, o saldo da balança comercial brasileira foi de US $\$ 2,5$ bilhões. Este valor engloba todos os setores participantes da economia nacional, porém, quando é analisada exclusivamente a balança comercial do agronegócio brasileiro, observa-se um saldo de cerca de US\$ 82,9 bilhões no mesmo ano, o que deixa evidente a alta dependência econômica brasileira do agronegócio (BRASIL, 2014).

Quando se fala em suprimento de alimentos, o Brasil figura como um dos principais exportadores mundiais de produtos como café, suco de laranja, carnes em geral, açúcar, soja e 
milho (NEVES et al., 2012) e possui níveis de crescimento em produtividade agrícola que o coloca entre os primeiros do mundo (GASQUES et al., 2012).

Segundo dados da Organização Mundial do Comércio (OMC, 2010), o Brasil tem a terceira colocação como maior exportador de alimentos do mundo, ficando atrás apenas da União Europeia e dos Estados Unidos. Desta maneira, o País possui importante papel na missão de alimentar a população com demanda crescente por alimentos.

Apesar da grandeza do setor agropecuário no Brasil e da sua grande participação nos números do País, este é ainda um setor que tem muito a ser melhorado. Produtores enfrentam uma grande diversidade de problemas como, por exemplo, as baixas margens praticadas, a dificuldade de diferenciação de produtos e consequente falta de agregação de valor ao mesmo, os altos custos que esbarram em problemas logísticos, as altas taxas tributárias, o déficit de infraestrutura, entre outros.

Além de problemas como esses, a produção agrícola é, por natureza, instável, uma vez que depende de muitas variáveis para se perpetuar com sucesso. A chegada de agentes biológicos desconhecidos ou indesejáveis pode ser crucial para a sobrevivência de uma cultura, bem como questões climáticas incontroláveis como a seca, por exemplo. Esses prejuízos podem se estender por todo o sistema agroindustrial, impactando fortemente nos preços observados no mercado.

Nos sistemas agroindustriais, as decisões são tomadas em ambientes instáveis, de grandes incertezas e alto risco. O desenvolvimento e a adoção de novas tecnologias são fundamentais para o sucesso financeiro das organizações no longo prazo e as organizações devem responder rapidamente às mudanças nas estruturas industriais e nos ambientes de concorrências para a manutenção de sua posição de mercado (BOEHLJE; ROUCAN-KANE; BRÖRING, 2011).

Tendo em vista essas questões, as ameaças que afetam o setor e a grande importância deste, tanto para a economia brasileira quanto, em uma visão global, para o abastecimento energético e alimentar do mundo, é necessário trabalhar constantemente na melhoria da sua competitividade.

Duas ferramentas amplamente utilizadas nos mais variados setores da economia para encarar todas as adversidades e manter a competitividade do setor são a gestão e o planejamento estratégico.

Os termos podem ser entendidos como o ato de entender a organização alvo internamente, mapeando seus recursos e suas deficiências, analisar o ambiente externo, bem como as ameaças e oportunidades oriundas do referido ambiente, definir objetivos e metas e 
por fim, criar planos que guiem a organização a atingir seus objetivos propostos (MINTZBERG, 1994; DRUCKER, 1998; TOLEDO; CAMPOMAR; TOLEDO, 2006; LAMBIN, 2012).

As organizações que adotam essas ferramentas conseguem ter maior controle sobre sua posição no mercado, pois são capazes de reagir antecipadamente às mudanças do ambiente externo e de utilizar seus recursos de forma potencializada para gerarem vantagens competitivas.

Apesar dos vários métodos de planejamento e gestão estratégica já propostos possuírem muitas características em comum (MACHADO FILHO; MARINO; CONEJERO, 2003; WOOD, 2004; BARBOSA; BRONDANI, 2004; HARRISON, 2005; KENAN, 2006; BRYSON; ALSTON, 2011; LAMBIN, 2012), eles variam de acordo com o setor de aplicação a que se propõem.

Além dos métodos propostos para organizações em geral, já foram propostos métodos para o planejamento estratégico de organizações públicas, sem fins lucrativos (NUTT; BACKOFF, 1987; BRYSON; ALSTON, 2011), para organizações específicas como uma instituição de ensino privada, por exemplo (FARIAS FILHO et al., 2011), para cadeias produtivas (NEVES, 2008; SENESI, 2013) e até mesmo para cidades (BORJA; CASTELLS, 1997; LOPES, 1998). Dentre os métodos de gestão estratégica propostos, foram revisados métodos de gestão estratégica de cooperativas agroindustriais e para o setor de agronegócios de um país (MACHADO FILHO; MARINO; CONEJERO, 2003; KENAN, 2006).

Um dos métodos de planejamento revisados, o planejamento estratégico de cidades, mostrou-se altamente complexo, por envolver aspectos relativos ao seu território e suas estruturas sociais, econômicas e políticas específicas que devem trabalhar em conjunto. Para tanto, diversas ferramentas foram incorporadas aos métodos de planejamento estratégico tradicionais (LOPES, 1998).

Em um contexto ainda mais complexo que aquele encontrado nas cidades, os estados também possuem suas especificidades.

Segundo Ferreira (1986, p. 714), dentre outras definições, um estado pode ser entendido como "[...] organismo político administrativo que, como nação soberana ou divisão territorial, ocupa um território determinado, é dirigido por governo próprio e se constitui pessoa jurídica de direito público, internacionalmente reconhecida"”, ou seja, os estados podem ser caracterizados como uma 'união' e seus direcionamentos e ações devem ser tomados conjuntamente. 
Como é observado no território brasileiro, suas regiões são caracterizadas por aspectos naturais que vão desde clima, vegetação e relevo até pragas e doenças específicas. No aspecto prático, torna-se difícil propor ações generalizadas para todos os biomas encontrados, devido justamente às suas especificidades.

Além das características supracitadas, em se tratando do agronegócio de um estado, pode-se definir seus concorrentes, tanto nacionais quanto internacionais, com maior facilidade. A concorrência nacional entre os estados ocorre principalmente na busca por investimentos públicos e privados. Um estado possui leis, políticas e regras que caracterizam um ambiente institucional próprio.

Quanto mais favorável e com maior perspectiva de crescimento for o ambiente institucional do estado, maior será o aporte de investimentos que receberá. Os investimentos praticados em nível estadual contribuem para movimentar a economia do estado, trazendo geração de empregos, distribuição de renda e desenvolvimento.

\subsection{Problema de pesquisa e objetivos}

Dada a grande importância do agronegócio para o Brasil e as especificidades encontradas em nível estadual, o presente trabalho busca, baseado nas informações e discussões realizadas e na reunião de diversas fontes de informações, responder à seguinte questão: É possível fazer a gestão estratégica de cadeias produtivas em um recorte estadual? Qual pode ser o método para sua execução?

A fim de solucionar o problema de pesquisa, são propostos: o objetivo geral do trabalho e seus objetivos específicos. A divisão entre objetivo geral e objetivos específicos é feita uma vez que o objetivo geral é o propósito final do trabalho, ou a principal lacuna a ser suprida, que norteia toda a execução da pesquisa. Já os objetivos específicos são contribuições pontuais que devem ser realizadas durante a execução do trabalho para que seja possível o alcance do objetivo final.

Assim, esta pesquisa tem como seu objetivo geral e final propor um método de gestão estratégica para cadeias produtivas em um contexto de recorte estadual.

Os objetivos específicos que permitirão o alcance do objetivo final do trabalho estão apresentados a seguir: 
- Identificar as contribuições de outros pesquisadores em temas relacionados à gestão e planejamento estratégico, cadeias produtivas e o planejamento de cadeias produtivas relacionado com o agronegócio.

- Analisar quais contribuições da literatura podem apresentar vantagens e quais podem apresentar desvantagens com relação ao método de gestão estratégica a ser proposto;

- Avaliar o método GESis como proposto por Neves (2008) e sua adaptação para o estado de Goiás;

- Estudar as características específicas de um estado da federação e como elas podem ser usadas beneficamente para o estado;

- Analisar a aplicação de um método de planejamento e gestão estratégica em cadeias produtivas do estado de Goiás;

Para tanto, além do estudo detalhado acerca do tema de planejamento e gestão estratégica, foram investigados estudos de caso $^{1}$ que contaram com a aplicação de um método de planejamento e gestão estratégica em cinco cadeias produtivas do estado de Goiás. A autora do presente trabalho participou ativamente da execução dos casos.

O que se espera é que, frente ao sucesso da aplicação do método de 'Gestão Estratégica para um Recorte Estadual' resultante do presente trabalho, a economia do setor como um todo obtenha vantagens competitivas que melhorem sua competitividade no enfrentamento de outros players. Olhando dessa forma, o esforço praticado pontualmente por cada um dos estados que forem submetidos ao método resultará em uma forma de organização geral do setor, posicionando-o melhor no mercado e trazendo grandes benefícios retroativos para cada um dos envolvidos.

\footnotetext{
${ }^{1}$ Os estudos de caso avaliados no presente trabalho são fruto de estudos e pesquisas realizadas pela Markestrat Centro de Pesquisa e Projetos em Marketing e Estratégia em parceria com a Federação das Indústrias do Estado de Goiás (FIEG) cuja autora do presente trabalho participou ativamente.
} 


\section{REFERENCIAL TEÓRICO}

\subsection{Os Sistemas Agroindustriais (SAGs);}

Apesar de os conceitos de Sistemas Agroindustrias (SAGs) e Sistemas de Agribusiness (agronegócio) confundirem-se muitas vezes devido às diversas sobreposições existentes entre eles, sua conceituação é fundamental para o entendimento e análise de um setor ligado aos alimentos.

O conceito de Sistemas Agroindustriais surgiu basicamente de dois estudos iniciais que forneceram diferentes abordagens a respeito do tema. $\mathrm{O}$ primeiro proposto por Davis e Goldberg (1957) e posteriormente complementado e aplicado a produtos específicos por Goldberg (1968) e o segundo, alguns anos mais tarde, nos estudos de Morvan (1985).

Na primeira abordagem, foi introduzido um conceito de fácil operacionalização, sendo facilmente utilizado por corporações e governo na execução das suas estratégias: o conceito do Enfoque do Sistema de Commodities -Commoditie System Approach (CSA). Nesse conceito, são enfatizadas as ligações necessárias para que o produto caminhe ao longo da cadeia, tratando da dependência intersetorial ali presente e mensurando a intensidade dessas ligações intersetoriais.

Goldberg (1968) definiu o termo como a união de todos os atores envolvidos com a produção, processamento e distribuição de um produto. Exemplos de agentes que estão envolvidos vão desde os fornecedores de insumos, até os envolvidos nas operações de atacado e varejo, passando por produtores, indústria, distribuidores e até às instituições que regulamentam todo esse sistema.

Resumindo, na visão proposta por Goldberg (1968), pode-se afirmar que o conceito de Sistema Agroindustrial é resultado da junção dos segmentos responsáveis pelas atividades antes, dentro e depois das fazendas, passando pelos agentes facilitadores de todo o processo, porém a organização desses agentes em uma estrutura sequencial ainda não estava completa.

Alguns anos depois, na França, Morvan (1985) propôs uma nova forma de analisar e estudar as cadeias, os chamados Sistemas Agroalimentares (filière). Apesar de apresentar muitas semelhanças com o CSA, desta vez a cadeia foi analisada como a união das várias operações necessárias para a transformação de um produto até que este chegue ao seu consumidor final. 
Para Morvan (1985), as cadeias são sistemas que podem garantir suas próprias transformações. Esse novo modo de análise permitiu que os sistemas fossem descritos mais claramente contribuindo, entre outras coisas, para a análise de interações sequenciais entre as organizações e o delineamento de estratégias coletivas.

Ambas as visões possuem similaridades de conceitos, uma vez que descrevem o processo produtivo enfatizando a variável tecnológica e mostram a interdependência de todos os elos envolvidos no sistema, sugerindo fortemente os conceitos de integração vertical e de ações coletivas. Ambas têm caráter descritivo e tratam de estratégia.

Apesar da aplicabilidade do conceito de agronegócio relacionado com os Sistemas Agroindustriais, ele ainda tinha um caráter muito descritivo, deixando a desejar quando se tratava da formulação de modelos e testes de hipóteses (ZYLBERSZTAJN, 1995).

Zylbersztajn (1995) complementou as teorias propostas por Davis e Goldberg (1957) e Morvan (1985), adicionando o suporte teórico da economia dos custos de transação. Dessa maneira, o campo analítico tradicional foi expandido, possibilitando testes de hipóteses acerca das estruturas de governança e das transações envolvidas no ambiente institucional.

No enfoque de Zylbersztajn (1995), a análise parte da governança que envolve os sistemas. Ele propõe que para se lidar com uma coordenação de sistemas agroindustriais é necessária a análise de duas variáveis que, interagindo entre si, resultam na forma final do modo de governança do sistema: os modos de governança oriundos das transações e aqueles que vêm do ambiente organizacional e institucional.

Zylbersztajn (1995) representou os principais elos dos SAGs e suas transações da maneira que é exposta na Figura 1. A maior parte das características propostas por Goldberg e Morvan também pode ser encontrada na mesma figura.

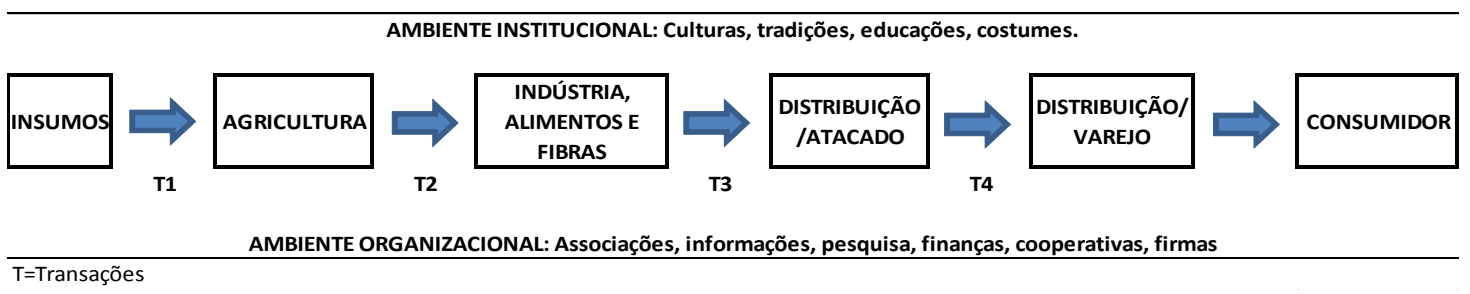

Figura 1 - Sistemas agroindustriais e transações típicas Fonte: Zylbersztajn (1995, p.174)

A grande contribuição dos estudos de cadeias de agroindústrias é a sua utilização para o desenho de políticas públicas, organização de empresas e estruturação de estratégias corporativas, porém muitos ainda enfrentam o problema da falta de uma abordagem sistêmica 
do agronegócio, resultando em falhas no desenho de estratégias corporativas e organizacionais (ZYLBERSZTAJN, 1995).

Em um enfoque tradicional de cadeias, Zylbersztajn e Neves (2000) sugerem que sejam considerados três subsistemas: o de insumos, o de produção e o de consumo, sendo que o último é caracterizado como a força central, que dá forma a um sistema relacionado ao agronegócio. Para os autores, deve-se distinguir o conceito de cadeia produtiva do conceito de Sistema Agroindustrial.

Em um SAG, são considerados elementos além somente daqueles envolvidos na cadeia vertical de produção, ressaltando o ambiente institucional no qual a cadeia está inserida e as organizações que dão suporte ao funcionamento da mesma. Dessa forma, o conceito de SAG aqui observado, se aproxima mais de "[...] um conjunto de relações contratuais entre empresas e agentes especializados, cujo objetivo final é disputar o consumidor de determinado produto" (ZYLBERSZTAJN; NEVES, 2000, p.13).

Em outra definição, os SAGs reúnem todas as fases necessárias para que um produto ligado à agroindústria chegue ao seu mercado consumidor, começando pela produção de insumos até o varejo que o disponibiliza no mercado (SAAB, NEVES, CLÁUDIO, 2009).

Para o pleno funcionamento de um Sistema Agroindustrial, é necessária uma complexa rede que una os elos que o compõe, portanto, os sistemas agroindustriais podem ser resumidos à soma de uma cadeia produtiva com a sua rede inter-organizacional.

Zylberstajn e Farina (2010) buscam diferenciar as redes das cadeias produtivas. Em uma conceituação inicial é proposto que as redes são arranjos institucionais complexos entre diversas firmas que, por meio da coordenação das transações, buscam criar e capturar valor. É destacado que as redes estão mais relacionadas com contratos contínuos de relação entre os diversos agentes e que elas devem ser conceituadas, desenvolvidas e utilizadas com o objetivo de viabilizar análises empíricas. Essas análises podem ser baseadas em três elementos: mecanismos de governança baseados na racionalização dos custos de transação; alocação dos direitos de decisão (autoridades); presença de confiança e inserção social.

O fluxo de produtos, serviços, informação, pedidos e pagamentos que vai desde o primeiro elo das cadeias, normalmente representado pelo setor de insumos, até o consumidor final é representado por empresas organizadas no complexo de redes agroalimentares (NEVES et al., 2000).

Os relacionamentos verticais refletem o fluxo de produtos e serviços do elo de produção até o consumidor final. Já os relacionamentos horizontais englobam os relacionamentos entre os atores de um mesmo elo (TRIENEKENS, 2011). 
Conejero (2011) conclui que as cadeias produtivas dizem respeito às integrações verticais existentes nos Sistemas Agroindustriais, enquanto que nas redes (networks) são englobadas as relações verticais, laterais e horizontais entre as organizações independentes.

$\mathrm{Na}$ atual conjuntura mundial, onde todas as áreas e setores estão cada vez mais dependentes de conexões entre si, a vantagem competitiva de uma organização é tão maior quanto melhor for sua capacidade de criar e manter uma rede inter-organizacional (OMTA; TRIENEKENS; BEERS, 2001).

Outro termo bastante encontrado em se tratando de Sistemas Agroindustriais é o termo 'cadeia de valor', o qual Porter (1998) foi o primeiro a definir. Sua definição se refere à cadeia de valor como uma maneira sistematizada de examinar todas as atividades que uma firma realiza e como se dá a interação dessas atividades.

O desenho da cadeia de valor serve como uma ferramenta que desagrega a organização nas suas atividades fundamentais e estratégicas, analisando os custos e as possíveis formas de diferenciação da mesma. Para o autor, uma rede de organizações pode ser entendida como uma rede de cadeias de valor independentes, que interagem entre si.

Assim como nos SAGs, o principal objetivo de uma cadeia de valor é o de produzir produtos ou serviços com valor agregado para o mercado por meio da transformação de recursos, dessa maneira, pode-se considerar que um Sistema Agroindustrial possui diversas cadeias de valor em sua estrutura que são diretamente ligadas a algum setor do agronegócio. As cadeias de valor podem ser vistas como um veículo capaz de introduz novas formas de produção, tecnologias, logística, processos e novas relações organizacionais (TRIENEKENS, 2011).

Para Harrison (2005, p.84) a cadeia de valor é "uma representação dos processos organizacionais, dividida em atividades primárias e de apoio, que cria valor para os clientes".

Uma real e explícita caracterização das cadeias de valor que compõem o agronegócio de uma economia é o primeiro passo para seu futuro planejamento (BOEHLJE; ROUCANKANE; BRÖRING, 2011).

Trienekens (2011) propõe em seu trabalho uma ferramenta para a análise de cadeias de valor em países em desenvolvimento. Para ele, as cadeias de valor nada mais são que relacionamentos de produção onde em que os atores do negócio exploram os recursos competitivamente e operam dentro de um ambiente institucional com o principal objetivo comum de prover produtos ou serviços para o mercado. São consideradas as relações horizontais e verticais envolvidas no sistema. 
Para uma real caracterização de uma cadeia de valor devem ser levados em consideração: sua estrutura de relacionamentos; sua forma de governança e a forma que o valor é adicionado no negócio.

Em outra abordagem, Hopkings e Wallerstein (1986) mencionam o conceito de cadeias de commodities. Para eles, o termo pode ser definido como uma rede de processos de produção e trabalhos, em que o resultado final é uma commodity terminada. É apontada uma visão a qual todas as firmas estão envolvidas nas cadeias da mesma maneira que os produtores e consumidores de insumos relacionam-se, direta ou indiretamente, com toda a rede.

Hopkings e Wallerstein (1986) propõem que a construção de uma cadeia de commodities deve ser feita de forma reversa, na qual são analisados inicialmente os consumidores do produto final e posteriormente os elos anteriores a ele. Essa abordagem deixa claro quais as origens do valor do produto para o consumidor, em vez de explorar os múltiplos usos de uma matéria prima no início da cadeia.

Com a chegada da globalização e o aumento das relações internacionais intra e intersetoriais, Gereffi, Humphrey e Sturgeon (2005) ampliaram o conceito de cadeia de commodities para uma análise global dos sistemas agroindustriais, propondo o termo de cadeia global de commodity - Global Commodity Chain (GCC). Seu foco se deu na emergência de um novo sistema de manufatura global, em que a integração econômica vai além do comércio internacional de matérias primas e produtos finais, buscando centralizar e coordenar em níveis internacionais uma cadeia na qual os agentes estão dispersos mundialmente.

Gereffi, Humphrey e Sturgeon (2005) identificaram quatro dimensões a serem analisadas nesse contexto: a estrutura de "input-output"; a cobertura geográfica; a estrutura de governança e o modelo institucional envolvido.

A partir desta seção, pode-se concluir que, inicialmente, o setor agrícola era algo isolado, apenas visto como ferramenta de subsistência. Com o passar dos anos, a necessidade de profissionalização do setor foi sendo destacada e novas correntes surgiram, buscando definir conceitos que facilitassem sua compreensão e posterior administração. Atualmente, os chamado Sistemas Agroindustriais seguem a mesma lógica de negócios utilizada por tantos outros setores, estando cada vez mais globalizados, apoiados em tecnologia e profissionalizados.

Essa tendência deve aumentar nos próximos anos, visto que o setor do agronegócio é o responsável pelo abastecimento de alimentos e energia do mundo, e se não for cada vez mais adaptado, não será capaz de fornecer a base que a futura população necessitará. 


\subsection{O conceito de Estratégia}

Uma das evidências do surgimento do conceito de estratégia ocorreu há milhares de anos (cerca de 400 a.c.) quando um general chinês conhecido como Sun Tzu, escreveu o livro "A Arte da Guerra" (The Art of War), onde eram descritas suas grandes estratégias responsáveis pelas diversas vitórias conquistadas nas guerras do período (MCNEILLY, 1996).

Inicialmente, a estratégia era algo inerente ao negócio que estava sendo realizado, não se constituía em um termo definido formalmente, apenas era utilizada devido à necessidade de se ter direcionamento para ações.

McNeilly (1996), estudando a obra de Sun Tzu, procurou formalizar as estratégias ali presentes e propôs seis princípios estratégicos. São eles: (1) capturar o mercado sem o destruir; (2) surpreender na hora que menos se esperar; (3) maximizar o poder das informações de mercado; (4) mover-se rapidamente para superar os competidores; (5) empregar estratégias para dominar a competição e (6) proporcionar uma liderança eficaz em tempos turbulentos. Estes princípios possuem fortes traços de estratégias para a guerra, mas tais estratégias podem ser amplamente adaptadas e muito bem aceitas no universo dos negócios.

Atualmente, são diversos os autores que definem o termo "estratégia", e apesar de as definições não serem iguais, elas possuem muitas semelhanças (BARBOSA; BRONDANI, 2004; HAX; MAJLUF, 1996; LAMBIN, 2012; DRUCKER, 2006; SILVA, BARCELOS, FALCHETTI., 2010)

Mintzberg, et. alii em seu livro Safári da Estratégia (MINTZBERG; AHLSTRAND; LAMPEL, 2010), afirmam que o termo estratégia pode ser definido a partir cinco ângulos: estratégia como planos (plano de ação para uma empresa adquirir vantagem competitiva); como padrões (consistência de comportamento que gera confiabilidade); como pretexto (como um 'truque', induz competidores a uma visão equivocada de seus movimentos); como posições (o posicionamento de determinados produtos em determinados mercados); e como perspectivas (a maneira fundamental de uma organização fazer as coisas).

Para Mintzberg, Ahlstrand e Lampel (2010), genericamente a estratégia deve ser vista como um processo, que apresentando certo grau de formalidade é capaz de articular resultados ou como uma forma de pensar no futuro integrado no processo decisório. 
Drucker (2006) afirma que a estratégia nada mais é do que a conversão de um conjunto de hipóteses (qual é o seu negócio; quais são os objetivos; como são definidos os resultados; quem são os clientes e qual valor eles pagam pelo produto ou serviço). Ela guia a organização a atingir seus objetivos em um ambiente incerto. $\mathrm{O}$ autor afirma que "[...] a estratégia lhe permite ser intencionalmente oportunista" (DRUCKER, 2006, p.42) devendo ser redesenhada emergencialmente por organizações que estão incapazes de produzir resultados esperados.

Ansoff (1965) destaca a importante diferença entre o objetivo e a estratégia, afirmando que o ponto que se quer alcançar é o objetivo, e os meios para se chegar a esse objetivo são as estratégias. É importante destacar que a mensuração dos objetivos estratégicos por meio de metas é fundamental no sucesso de sua execução.

Já para Silva, Barcelos e Falchetti (2010,p. 7):

Nas significações que lhe são atribuídas, a estratégia geralmente está relacionada à
prévia análise de reconhecimento, buscando saber qual a real posição, quais os
recursos que dispõe, com que trunfos se conta, quais os pontos vulneráveis, para, a
partir de então, fosse no campo militar, político ou intelectual-filosófico, decidir-se
por um roteiro de ações que propicie a obtenção do objetivo pretendido.

Apesar das várias definições do termo "estratégia", genericamente pode-se falar que todo tipo de organização possui uma estratégia. A grande diferença das organizações com relação às estratégias é o grau de formalidade com que elas são formuladas e implementadas. Em outras palavras, todas as organizações possuem uma estratégia, por mais simples e informal que ela seja (HARRISON, 2005).

Em uma organização as estratégias podem ser divididas em três níveis. O primeiro nível diz respeito às estratégias organizacionais (ou corporativas) que são responsáveis pelas decisões gerais da organização definindo suas direções e objetivos no longo prazo. As estratégias organizacionais provêm ferramentas que levem a organização a atingir seus objetivos gerais respeitando seus recursos e capacidades.

O segundo nível estratégico de uma organização diz respeito às estratégias de negócio. Elas definem o escopo estratégico de cada unidade de negócio dentro da organização. Pode-se dizer que as estratégias de cada unidade de negócio devem trabalhar para atingirem juntas, o objetivo geral da organização.

O terceiro e último nível estratégico é referente às estratégias de marketing. Esse nível estratégico é utilizado para que cada unidade de negócio defina suas estratégias de utilização das ferramentas para produto, praça, preço e promoção do mix de marketing, a fim de satisfazer seus objetivos estratégicos (WOOD, 2004). 
As ações tomadas a partir de uma estratégia devem direcionar a organização no cumprimento de suas metas de curto prazo e objetivos de longo prazo visando sempre à criação das vantagens competitivas para a organização, aumentando, consequentemente, sua competitividade. Porém, como saber se a empresa está trabalhando com uma vantagem competitiva ou com apenas uma estratégia genérica facilmente estruturada pelos concorrentes? Para dar subsídios a esta questão, os termos "vantagem competitiva" e "competitividade" devem ser explorados.

\subsection{A criação da vantagem competitiva e a competitividade}

A vantagem competitiva surge quando uma firma é capaz de criar um valor para os seus clientes que excede o custo enfrentado para a sua criação (PORTER, 1980), porém, muito além das questões financeiras, a criação de vantagens no mercado está diretamente relacionada com a capacidade dos concorrentes em criarem suas próprias estratégias na busca de melhores posicionamentos no mercado.

A sustentação de uma vantagem competitiva está diretamente ligada ao fato de se usar uma estratégia de criação de valor que não está sendo desenvolvida simultaneamente pelos concorrentes e para a qual outras firmas não são capazes de replicar seus benefícios. A estratégia com vantagem competitiva deve prover uma oportunidade em redução de custos no oferecimento de um produto ou serviço com estratégia de diferenciação para um amplo segmento de mercado (BARNEY, 1991; O'SHANASSY, 2008).

Dentro do conceito de vantagem competitiva, Harrison (2005) usa o termo 'vantagem competitiva sustentável'. Esse termo diz respeito a uma vantagem competitiva que se mantém no longo prazo e deve ser diferenciado do 'marketing sustentável', definido como o estabelecimento, manutenção e aperfeiçoamento das relações com os consumidores, em que os objetivos das partes envolvidas são satisfeitos sem comprometer a habilidade das futuras gerações em atingir seus próprios objetivos (BRASSINGTON; PETTITT, 2003).

Para Harrison (2005), existem cinco grandes áreas que devem ter 'recursos ou aptidões' disponíveis para que seja criada e sustentada uma vantagem competitiva no mercado, são elas: financeira, física, humana, baseada em conhecimento e organizacional geral. 
Para que um 'recurso ou aptidão' organizacional gere uma vantagem competitiva sustentável, ele deve: (1) ter valor no mercado; (2) ser único; (3) não ter um substituto imediato disponível; (4) estar inserido em um sistema organizacional que permita seu funcionamento potencial; (5) ser conhecido por todos da organização e ter claras as suas vantagens e; (6) ser de difícil imitação. Os 'recursos ou aptidões' que devem ser trabalhados são diferentes dependendo do foco ou segmento da organização e apresentam a possibilidade de mudanças com o passar do tempo.

Devido às características já discutidas acerca dos sistemas agroindustriais, estratégias para aumentar sua competitividade devem ser muito bem delineadas. A competitividade de um sistema agroindustrial pode ser analisada a partir de três frentes diferentes: estratégias privadas, estratégias coletivas e políticas públicas (ZYLBERSZTAJN; NEVES, 2000).

ESTRATÉGIAS PRIVADAS: As estratégias privadas, estão relacionadas com as ações realizadas pelas empresas privadas a fim de aumentarem sua competitividade, normalmente impulsionadas por aumento de margens. Essas estratégias estão, na maioria das vezes, ligadas a redução de custos ou agregação de valor no produto final. Uma vez que a maior parte dos produtos do agronegócio é tratada como commodities, com preços préestabelecidos, a estratégia mais utilizada é a de redução de custos a partir do ganho de escala na produção e de sistemas eficientes de logística (ZYLBERSZTAJN; NEVES, 2000).

ESTRATÉGIAS COLETIVAS: No âmbito das estratégias coletivas são consideradas as organizações verticais e horizontais, que agregam os participantes da cadeia em prol de objetivos comuns. Zylbersztajn e Neves (2000) propõem que essas estratégias facilitem a articulação do setor com órgãos governamentais, pressionando o estabelecimento das regras do jogo.

Devido ao seu caráter, as estratégias coletivas são guiadas para resultados no longo prazo, que dependem de movimentações políticas. Outros aspectos das estratégias coletivas estão relacionados com o auxílio na mediação de conflitos e estabelecimentos de padrões e normas que favorecem o setor e principalmente com a coordenação dos Sistemas Agroindustriais.

A competitividade de um SAG está diretamente ligada ao seu grau de coordenação. Uma vez que os relacionamentos verticais refletem o fluxo de produtos e serviços do elo de produção até o consumidor final e os horizontais englobam os relacionamentos entre os atores de um mesmo elo (TRIENEKENS, 2011), conclui-se que ambas as redes devem estar plenamente coordenadas para atingir seu mais alto grau de competitividade. 
O agronegócio brasileiro e sua indústria de alimentos são caracterizados por uma grande e complexa rede de atores, que se relacionam direta e indiretamente, porém ainda apresentam baixo grau de coordenação.

Devido à grande extensão da produção agrícola e seu caráter difuso, os esforços para a realização de ações conjuntas são difíceis, o que demanda cada vez mais, iniciativas que propiciem a execução das estratégias coletivas, a fim de agregar seus participantes.

Em se tratando de políticas públicas, o Estado exerce papel fundamental no seu estabelecimento, sempre objetivando a criação de condições e instituições que coordenem os sistemas (ZYLBERSZTAJN; NEVES, 2000).

Como proposto por North (2004), a sociedade está inserida em um ambiente institucional que se faz presente a fim de reduzir as incertezas, propiciando uma estrutura estável para as interações.

No agronegócio não é diferente. As instituições realizam o delineamento de regras que regulamentam o 'jogo econômico' e garantem as operações e eficiências dos sistemas. Essas regras são formalizadas por meio das políticas públicas, que podem ser divididas em políticas macroeconômicas e políticas setoriais. As macroeconômicas dizem respeito à economia de maneira genérica, possuindo uma atuação mais ampla e aplicável aos mais variados setores, como por exemplo, as políticas cambiais, fiscais e monetárias. Já as políticas setoriais, como o próprio nome já explicita, são específicas para determinados setores (LEITE, ET AL., 2009).

Diante do cenário que se apresenta para o agronegócio brasileiro, o Estado possui papel fundamental na regulação do ambiente institucional. Muitas políticas públicas são delineadas em vistas de organizar, facilitar e favorecer a perpetuação do setor. O governo busca atuar de forma a mitigar parte dos riscos oferecidos a atividade e fornecer subsídios para o desenvolvimento por meio de políticas setoriais.

As políticas públicas federais direcionadas para a agricultura e pecuária do Brasil podem ser encontradas nos chamados Planos Agrícola e Pecuário, publicado pelo Ministério da Agricultura, Pecuária e Abastecimento a cada ano/safra (BRASIL, 2012b).

Para o ano safra 2012/2013, algumas das políticas públicas destinadas ao setor são:

- Política de crédito rural: dispõe linhas de crédito para custeio, comercialização e investimento e consolida-se como um dos principais instrumentos de fomento à agricultura.

A Política de Crédito Rural também possui modalidades específicas de financiamento como a Política de Produção Sustentável no Campo (Agricultura de Baixo Carbono), o Programa de Modernização da Agricultura e Conservação dos Recursos Naturais (Moderagro), a Política de Apoio ao Médio Produtor Rural (Pronamp), a Política de Apoio às 
Cooperativas de Produção Agropecuária (Procap-agro e Prodecoop) e a Política de Apoio à Armazenagem e à Irrigação (Moderinfra), cada uma contando com limites, encargos e prazos de pagamentos específicos.

- Apoio à comercialização: conta com a Política de Garantia de Preços Mínimos, que busca mitigar as variações de preços agropecuários por meio do estabelecimento de um parâmetro de preço de garantia baseado nos custos variáveis das culturas. Dessa forma, as decisões tomadas no campo, como as de plantio, por exemplo, podem ser feitas em um ambiente mais seguro.

Outros instrumentos como Aquisição do Governo Federal (AGF) e Contratos de Opção de Vendas, por exemplo, também funcionam como apoio à comercialização.

- Gestão de Risco Rural: este programa oferece políticas que buscam reduzir as incertezas enfrentadas pelos produtores rurais. Dentre algumas das políticas que ele envolve e busca sempre o aperfeiçoamento estão o Zoneamento Agrícola de Risco Climático e o Programa de Subvenção ao Prêmio do Seguro Rural.

No zoneamento agrícola é elaborado um calendário de plantio por município de acordo com características de solos e séries históricas climáticas, servindo como um guia para o produtor. Já o Programa de Subvenção ao Seguro Rural (PSR) é complementar aos programas de crédito e apoio à comercialização, oferecendo proteção ao produtor rural frente a perdas decorrentes de fenômenos imprevistos.

Frente às grandes diferenças econômicas, sociais e ambientais observadas entre as regiões do Brasil, as políticas públicas para o setor agrícola apresentam uma tendência de regionalização.

O Plano Agrícola e Pecuário 2012/2013 traz a regionalização de políticas agrícolas para que sejam feitas adequações a fim de considerar as especificidades e desafios locais. Um exemplo é a suinocultura na região Sul do País que, frente a situações emergenciais, recebeu linhas de financiamentos adicionais de custeio para a retenção de matrizes, por exemplo. (BRASIL, 2012b).

Além das políticas públicas nacionais, os estados possuem suas secretarias específicas que também criam políticas direcionadas para setores específicos. O estado de Goiás conta com a Secretaria de Estado de Agricultura, Pecuária e Irrigação (SEAGRI) que tem como competências fundamentais (SECRETARIA DO ESTADO DE GESTÃO E PLANEJAMENTO, 2013):

Formulação e execução da política agrícola estadual, regularização fundiária, aquicultura e pesca; formulação das políticas de assistência técnica e extensão rural, pesquisa agropecuária, sanidade animal e vegetal e abastecimento; fomento ao 
desenvolvimento rural e fundiário; supervisão, coordenação, acompanhamento, controle, execução e desenvolvimento de projetos de irrigação de interesse do Estado de Goiás.

O estabelecimento de políticas públicas, tanto federais quanto regionais, visa sempre ao aumento da competitividade do setor seja por meio de melhorias em produtividade, melhores gerenciamentos das atividades ou até mesmo facilitando negociações com outros players internacionais.

A efetividade de algumas políticas públicas na promoção do agronegócio brasileiro foi comprovada por Gasques et al. (2012), quando os pesquisadores testaram o efeito dessas políticas, mais especificamente do crédito rural, exportações e pesquisa, na produtividade agrícola brasileira. A conclusão foi de que as políticas públicas são essenciais para o agronegócio de certa localidade, pois, fornecendo a liquidez necessária para lidar com a defasagem de tempo encontrada em diversas produções agrícolas, facilitam a compra de insumos de qualidade, a adoção de novas tecnologias e a ampliação de escalas de produção.

Com a profissionalização dos setores agrícolas, e sua caracterização como Sistemas Agroindustriais, seu planejamento e administração tornou-se algo fundamental. Tanto os conceitos de estratégia quanto os de vantagem competitiva são plenamente aplicáveis aos sistemas agroindustriais, porém estes possuem algumas particularidades que devem ser levadas em conta em sua administração como o alto nível de incertezas envolvidas no negócio.

\subsection{As incertezas estratégicas}

O campo das incertezas no agronegócio é muito complexo. Fatores como o clima, pragas, condições de mercado, comportamento dos concorrentes, mudanças em regulamentações políticas, novas doenças infecciosas, crises energéticas, alterações de biodiversidade, entre outros, incidem diretamente sobre um sistema agroindustrial e fogem ao controle dos envolvidos no negócio, ampliando a necessidade de pessoas capacitadas para a tomada de decisões nos mais variados ambientes (DETRE et al., 2006; NEVES, 2005; NIEME; NIEME; NIEME, 2010).

Além da grande quantidade de incertezas, mais especificamente no universo dos empreendimentos rurais uma miopia nas áreas de planejamento e gestão ocorre frequentemente devido ao grande envolvimento das mesas nas áreas técnica e operacional 
(SILVA; BARCELOS; FALCHETTI., 2010), aumentando o risco associado a falta de previsões e planos de ação.

A adoção e implementação de mudanças e inovações que requerem ajustes e adaptações de todos os elos da cadeia de um SAG são muito mais difíceis quando a cadeia é, além de complexa, fragmentada e não coordenada (BOEHLJE; ROUCAN-KANE; BRÖRING, 2011)

É grande a dificuldade para se analisar todas essas incertezas, e as estratégias para lidar com elas são complexas; no entanto, com um bom sistema de análise e planejamento, podem emergir oportunidades de criação de valor e aumento dos lucros (DETRE et al., 2006).

A fim de minimizar os problemas oriundos dos altos graus de incerteza, mensurações objetivas devem ser realizadas, porém esta não é uma tarefa fácil. Como primeiro passo para a sistematização das incertezas, Detre et al., (2006) procuram enquadrar as incertezas em uma das seis categorias que seguem: negócios/operacional; financeiro; condições de mercado; tecnologia; relacionamentos do negócio e políticas e regulamentações. A avaliação e gerenciamento dessas incertezas por meio de estratégias proativas, resultam na captura dos benefícios potenciais e na mitigação de possíveis exposições caso ocorram falhas.

A identificação das incertezas de um negócio, além de ser primordial para o delineamento de estratégias, é um primeiro passo mais fácil de ser conduzido. Muitas firmas conseguem identificar as incertezas relacionadas ao seu negócio, porém não têm claros os métodos de como lidar com tais incertezas, não sendo capazes de criar políticas que mitiguem as exposições e muito menos que sejam capazes de capturar o valor potencial que elas possuem (BALDONI, 2001).

Como em todas as áreas, o sucesso emerge da capacidade de enxergar oportunidade em todos os aspectos do negócio. Com as incertezas estratégicas, o conceito não é diferente. Elas devem ser trabalhadas de maneira que algum valor seja criado e capturado pela organização a proporcionando vantagem competitiva frente aos seus concorrentes.

Pensando nas formas de sistematizar as decisões frente a situações de grandes incertezas e obter vantagens a partir das mesmas, Boehlje; Roucan-kane e Bröring (2011) elencam duas possíveis ferramentas.

A primeira delas é por meio de um modelo para tomada de decisão. Neste modelo, a tomada de decisão é feita baseada em uma árvore que sistematiza as decisões. A Figura 2 ilustra a árvore de decisão que pode ser adotada. 


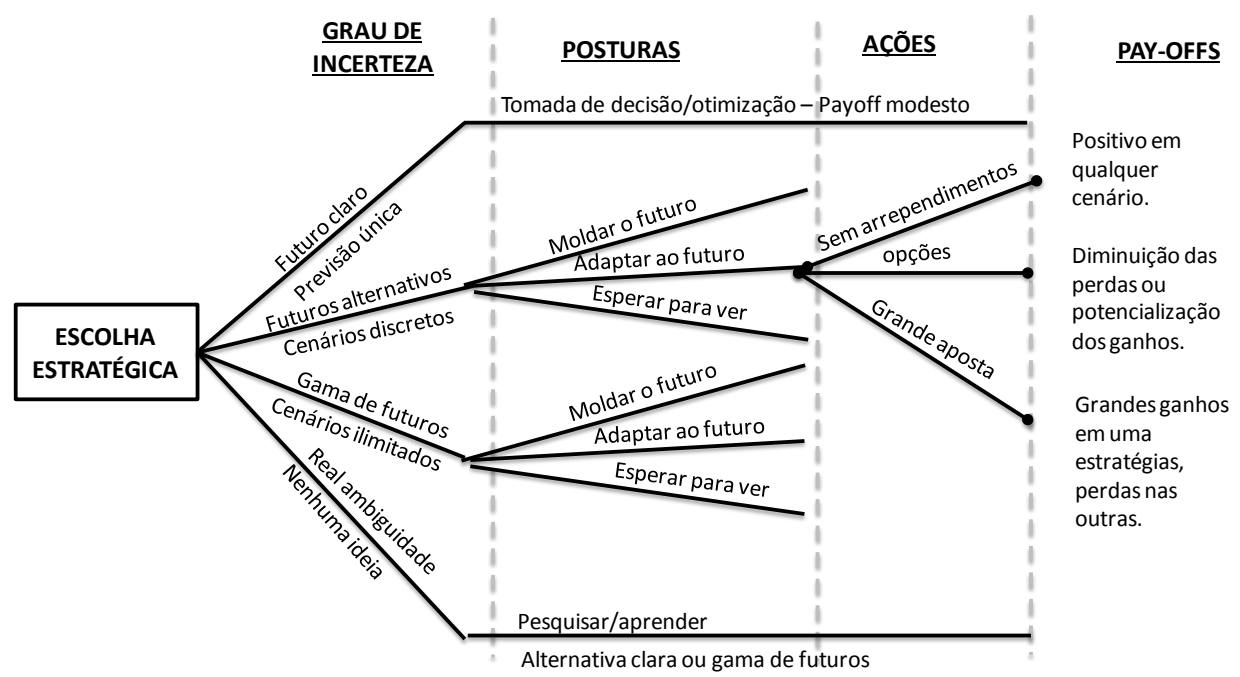

Figura 2 - Árvore de decisão para escolhas estratégicas em um ambiente de incerteza. Fonte: Adaptado de Boehlje, Roucan-Kane e Bröring (2011).

Este modelo pode ser dividido em duas fases. A primeira consta da decisão do posicionamento estratégico da organização, que pode ser traduzido pelas intenções organizacionais, já a segunda diz respeito à definição de um portfólio de atividades e ações que a organização deve optar para atingir seu objetivo estratégico. A execução de um mapa, como o proposto pelos autores, é capaz de simular os cenários futuros e seus respectivos payoffs, habilitando os tomadores de decisão a escolher o grau de risco que desejam enfrentar no futuro, podendo ser mais conservadores ou mais agressivos nas suas escolhas.

A segunda conduta a ser tomada em um ambiente de incerteza é a da utilização da compra de 'opções reais'. Este caso funciona como a compra de 'opções financeiras' na bolsa de valores, onde se adquire o direito de optar por manter ou não uma posição no futuro.

Da mesma maneira que a árvore de decisão apresentada anteriormente, diversas ferramentas são capazes de auxiliar no planejamento e gerenciamento das organizações, a fim de criar vantagens competitivas e valor para elas.

Uma vez que o ambiente de decisão ao qual os sistemas agroindustriais estão inseridos é complexo e caracterizado por processos não lineares e informações limitadas podem restringir a capacidade de um sistema de criar valor ao longo do tempo, o processo de decisão para tal requer ferramentas analíticas mais complexas que aquelas usadas no tradicional equilíbrio que guia a teoria econômica da firma (BEINHOCKER, 2007; PORAY et al., 2003).

As ferramentas analíticas utilizadas em sistemas industriais (ou agroindustriais) devem ser dinâmicas tanto nas dimensões de tempo quanto nas de incertezas (BOEHLJE; ROUCANKANE; BRÖRING, 2011) 


\subsection{O Planejamento Estratégico}

Começando pela definição do termo de planejamento, Loasby (1976) afirmou que ele é tão amplo e largamente utilizado em diversos locais com diferentes significados que corre riscos de extinguir-se no tempo. Os esforços para a definição do termo são muitos, porém devemos assumir algumas das suas conceituações para que o entendimento do planejamento estratégico seja pleno.

Em sua obra, Mintzberg (1994) propõe algumas definições formais para planejamento: (1) planejamento é o pensamento futuro; (2) planejamento é o ato de controlar o futuro; (3) planejamento são decisões tomadas integradamente; (4) planejamento é o procedimento formal para produzir e articular resultados na forma de um sistema integrado de decisões; e conclui afirmando que o planejamento não é a simples ação de criar planos, envolvendo muitas outras dimensões.

Para Toledo, Campomar e Toledo (2006, p. 66):

O planejamento, nos níveis estratégico, tático e operacional, revela-se como o mecanismo que permite o ajuste, tendo em vista a conquista de vantagens competitivas sustentáveis e o consequente alcance de crescimento e rentabilidade, em um ambiente caracterizado por mudanças incontroláveis e imprevistas.

Silva, Barcelos, Falchetti (2010, p. 14) afirmam que "O ato de planejar traz ganhos econômicos, sociais e culturais".

Uma vez que o sucesso de uma firma está amplamente relacionado com a sua sobrevivência e crescimento no longo prazo e não apenas com o seu sucesso financeiro no curto prazo, a organização deve estar focada na sua capacidade de antecipar as mudanças de mercado e adaptar sua estrutura e seu portfólio a essas mudanças. Para o sucesso da organização, fazem-se, então, necessários seu planejamento, gestão e administração estratégica, sendo que o ponto de partida deve ser a organização sistemática de toda a informação (LAMBIN, 2012).

Unindo os conceitos de planejamento e estratégia, Drucker (1998, p.136) define o termo 'Planejamento Estratégico' da seguinte maneira:

É o processo contínuo de, sistematicamente e com maior conhecimento possível do futuro contido, tomar decisões atuais que envolvam riscos; organizar sistematicamente as atividades necessárias à execução dessas decisões; e, por meio de uma retroalimentação organizada e sistemática, medir o resultado dessas decisões em confronto com as expectativas almejadas. 
O planejamento estratégico é a adequação de um plano para a execução das estratégias ou um plano para que as estratégias já identificadas sejam executadas (MINTZBER, 1994), e deve satisfazer as seguintes condições:

- Ser responsável pela adaptação organizacional às constantes mudanças ambientais que a cercam;

- Estar alinhado com um horizonte de tempo longo, ou seja, as ações devem ser estabelecidas para resultados no longo-prazo;

- Ser entendido como um processo agregador, que une os vários aspectos de uma organização (técnicos, humanos, estrutural, etc) na busca da satisfação de um objetivo comum;

- Buscar emergir com um consenso a partir de debates e da multiplicidade de opiniões entre todos os níveis organizacionais, sempre visando o alcance dos objetivos da organização;

Zuin e Queiroz (2006) afirmam que o planejamento estratégico é essencial para a busca e manutenção da competitividade de uma organização, e que em se tratando de empreendimentos rurais, esse processo se torna ainda mais necessário por se tratar de um negócio complexo associado a riscos altamente instáveis. Nos sistemas agroindustriais, a formulação de estratégias e de políticas deve ser fundamentalmente balizada pelas relações verticais de produção encontradas na cadeia (ZYLBERSZTAJN; NEVES, 2000).

Muitos são os benefícios que o planejamento estratégico, quando bem estruturado e aplicado, pode trazer para uma organização.

A efetividade da organização é aprimorada uma vez que sua missão é definida, seus valores são honrados e ela adquire a habilidade de responder rapidamente às diferentes circunstâncias enfrentadas como mudanças ambientais, por exemplo. O aprendizado organizacional é melhorado uma vez que a organização passa a compreender mais claramente sua real situação sendo capaz de reconceitualizar-se e trabalhar para estabelecer novas ferramentas de interpretação (BRYSON; ALSTON, 2011).

Tanto a comunicação quanto as relações interpessoais são potencializadas, uma vez que aspectos como missão, visão, valores, estratégias e objetivos são compartilhados entre todos, atingindo principalmente os tomadores de decisões, porém ficando claro para todos os envolvidos no negócio. Consequentemente, em um ambiente no qual as informações são mais claras e organizadas, além das decisões serem tomadas de maneira mais eficiente, o apoio político a tais decisões é maior, resultando em maior legitimidade organizacional (BRYSON; ALSTON, 2011). 
Uma vez caracterizado, para que o planejamento estratégico seja pleno, a organização tem papel fundamental, devendo estar atenta a três aspectos durante todo o processo: onde ela está, onde ela quer chegar e como chegar ao objetivo final (BRYSON; ALSTON, 2011).

Jean-Jacques Lambin em seu livro Market-Driven Management: Estrategic and Operational Marketing, detalha ainda mais as questões que devem ser seguidas para que se tenha um planejamento estratégico satisfatório. Para o autor, devem ser providas respostas para seis questões fundamentais:

1. O que somos (a organização) e qual a nossa missão no mercado que atuamos?

2. Dentro do mercado de atuação, quais são nossos produtos ou segmentos alvo e qual deve ser nosso posicionamento estratégico dentro de cada segmento?

3. Quais são os fatores chave de atratividade do negócio para cada segmento e quais são as ameaças e oportunidades oriundas do ambiente que nos cerca?

4. Dentro de cada segmento, quem são nossas qualidades, forças, fraquezas e vantagens competitivas?

5. Quais estratégias de desenvolvimento devem ser adotadas por cada setor em um desenvolvimento de portfólio de produtos?

6. Como essas estratégias podem ser traduzidas em programas operacionais de marketing definidos em termos de produto, distribuição, preço e decisões de comunicação? (LAMBIN, 2012).

Os métodos de planejamento estratégico são aplicados nas mais diversas áreas, que vão desde organizações privadas que buscam o aumento da sua competitividade e, muito mais que isso, sua perpetuação no mercado, até àquelas organizações sem fins lucrativos.

Bryson e Alston (2011) destacam a importância do planejamento estratégico para organizações públicas e sem fins lucrativos. Eles afirmam que para a grande maioria delas, o planejamento estratégico é um 'modo de vida', sendo considerado a prática organizacional padrão.

Muitos são os motivos para essa ampla adoção da ferramenta que vão desde leis que incidem sobre órgãos públicos, obrigando-os a adotar uma prática de planejamento, até a simples cópia do que todos estão fazendo. Porém, este tipo de organização necessita de serviços e resultados eficazes e transparentes uma vez que, além de fatores como a diminuição da ajuda externa e a situação econômica do país, estão trabalhando com dinheiro público e podem ter o questionamento da sua idoneidade (CARVALHO, 2004).

Outro exemplo da aplicação de um método de planejamento estratégico pode ser encontrado no trabalho de Farias Filho et al. (2011), em que foi avaliada a aplicação em uma 
instituição de ensino, tendo como um dos resultados as principais razões para adoção da ferramenta.

Algumas das razões encontradas por Farias Filho et al. (2011) são: ter visão de futuro, fortalecer as bases da instituição para o alcance da missão institucional, definir objetivos estratégicos, definir as prioridades da organização, decidir aonde chegar em termos organizacionais, ter dinâmica institucional consoante com a dinâmica da sociedade, fortalecer a identidade institucional, organizar e crescer a gestão, sobreviver em um mercado competitivo, ter uma projeção financeira e ter um bom sistema de planejamento.

Muitos são os desafios enfrentados para que o País cumpra competitivamente seu papel de fornecedor mundial de alimentos. Para transpor esses desafios, o planejamento e estratégico é fundamental uma vez que, mediante o uso das ferramentas adequadas, a empresa diagnostica os principais gargalos a serem superados, monitora as mudanças no macroambiente que o setor está inserido e indica os direcionamentos e ações a serem tomadas para tal.

\subsubsection{O planejamento de Marketing}

O planejamento de marketing é muitas vezes interpretado da mesma maneira que o planejamento estratégico, porém eles possuem distinções.

Wood (2004) caracteriza muito bem as diferenças do planejamento estratégico e do planejamento de marketing estabelecendo uma relação entre eles. Para o autor, que divide as estratégias dentro de uma organização em estratégias organizacionais, estratégias de unidades de negócio e estratégias de marketing, o planejamento estratégico é referente às estratégias organizacionais, sendo o plano geral da organização e devendo ser desenvolvido pela alta gerência executiva.

O plano de marketing trata do planejamento das estratégias de marketing, sendo mais focado no planejamento das estratégias utilizadas em cada unidade de negócio para atingir os seus objetivos (WOOD, 2004).

Em vias gerais, os passos adotados em um planejamento estratégico e em um planejamento de marketing são muito próximos, causando confusões entre os termos, porém genericamente o que difere um do outro não são os passos a serem adotados, mas sim o nível organizacional onde ele será aplicado. Dessa forma, aspectos encontrados em um 
planejamento de marketing podem ser utilizados em um planejamento estratégico e viceversa, dependendo do contexto.

Toledo, Campomar e Toledo (2006, p.47) afirmam que:

[...] o plano de marketing desempenha um papel indispensável como instrumento facilitador, integrador e "potencializador" das estratégias empresariais em cenários competitivos caracterizados por crescente complexidade, volatilidade e incerteza.

Um plano de marketing deve contemplar basicamente cinco grandes etapas fundamentais. A partir delas, cada plano é adaptado para o contexto que se busca estudar ou planejar. São elas:

1. Análise da situação interna e externa;

2. Objetivos;

3. Estratégias gerais;

4. Programa ou plano de ação;

5. Acompanhamento e controle (TOLEDO; CAMPOMAR; TOLEDO, 2006).

\subsection{Do planejamento estratégico à gestão estratégica}

Segundo Ansoff (1980), o planejamento estratégico tem o propósito de mudar as ações estratégicas de uma organização, enquanto que a gestão estratégica, além de trabalhar com as ações, também busca modificar algumas capacidades das organizações.

Mintzberg (1994), por sua vez, afirma que o planejamento estratégico restringe-se à execução de estratégias já identificadas, resando na criação de um plano. Por não contemplar necessariamente o pensamento estratégico, o planejamento estratégico torna-se uma ferramenta rígida.

Harrison (2005, p.40) define então que "a gestão estratégica eficaz inclui o pensamento estratégico e os elementos essenciais do processo de planejamento estratégico".

O conceito de administração estratégica, ou gestão estratégica, surgiu em maio de 1977 em uma conferência na Universidade de Pittsburgh, na qual diversos professores e pesquisadores de política empresarial buscavam soluções para as recentes mudanças no cenário econômico e empresarial causado pelo final da Segunda Guerra Mundial. A partir de então, o campo da gestão estratégica veio crescendo a cada ano, impulsionado por pesquisadores que buscam determinar as técnicas e estratégias adotadas pelas empresas bem sucedidas (HARRISON, 2005). 
De acordo com Harrison (2005, p.28), o método tradicional de administração estratégica consiste em:

[...] análise dos ambientes internos e externos da companhia para descobrir os pontos fortes, os pontos fracos, oportunidades e ameaças da organização, que são base para o desenvolvimento de missão, objetivos e estratégias.

Dessa maneira, a gestão estratégica pode ser entendida como o processo em que as organizações aprendem a partir da análise de seu ambiente externo e interno, traçam objetivos e metas estratégicas, criam planos estratégicos para atingir seus objetivos e implementam as estratégias, sempre buscando satisfazer as necessidades do seu público interessado (HARRISON, 2005).

Para Carvalho (2004), a gestão estratégica envolve não somente as ações relacionadas com o planejamento das estratégias e acompanhamento das suas execuções, mas também a concepção da estratégia incluindo o pensamento estratégico da organização e etapas como o seu planejamento financeiro.

$\mathrm{Na}$ próxima seção serão revisados métodos de planejamento estratégico, gestão estratégica e planejamento de marketing, buscando dar maior consistência teórica ao método de gestão estratégica que será proposto no presente trabalho.

\subsection{Métodos de planejamento estratégico, planejamento de marketing e gestão estratégica}

Para dar consistência ao método de gestão estratégica que será proposto neste trabalho, vários outros métodos foram avaliados. Nesta etapa são revisados métodos de planejamento estratégico, planejamento de marketing e gestão estratégica, uma vez que na maioria das vezes essas terminologias são utilizadas para designar um plano de criação e execução de uma estratégia.

O Quadro 1 e o Quadro 2 resumem as etapas de cada método estudado, e na sequência são apresentadas algumas particularidades desses métodos.. 


\begin{tabular}{|c|c|c|c|c|c|c|}
\hline 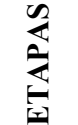 & Borja e Castells, 1997 & Lopes, 1998 & $\begin{array}{l}\text { Machado Filho, Marino e } \\
\text { Conejero, } 2003\end{array}$ & Wood, 2004 & Barbosa e Brondani, 2004 & Harrison, 2005 \\
\hline 1 & Definição de metas urbanas & Diagnóstico & $\begin{array}{l}\text { Realização de análise de } \\
\text { ambiente externo e interno }\end{array}$ & $\begin{array}{l}\text { Determinação de missão e } \\
\text { analise do ambiente interno e } \\
\text { externo }\end{array}$ & Entendimento da organização & $\begin{array}{l}\text { Análise dos ambientes, do } \\
\text { público interessado e dos } \\
\text { recursos organizacionais. }\end{array}$ \\
\hline 2 & $\begin{array}{l}\text { Manutenção da dialética entre } \\
\text { objetivos, projetos e } \\
\text { repercussões }\end{array}$ & $\begin{array}{l}\text { Definição de temas críticos a } \\
\text { serem analisados }\end{array}$ & $\begin{array}{l}\text { Determinação dos eixos } \\
\text { estratégicos }\end{array}$ & $\begin{array}{l}\text { Pesquisa e análise de mercados } \\
\text { e consumidores }\end{array}$ & Definir a missão & $\begin{array}{l}\text { Estabelecimento da direção } \\
\text { estratégica }\end{array}$ \\
\hline 3 & $\begin{array}{l}\text { Ação de agentes públicos e } \\
\text { privados de acordo com as fases } \\
\text { estabelecidas de preparação e } \\
\text { implementação do plano. }\end{array}$ & $\begin{array}{l}\text { Definição de missão e linha de } \\
\text { ação estratégica }\end{array}$ & Aplicação da ferramenta SWOT & $\begin{array}{l}\text { Determinação da segmentação, } \\
\text { alvos e posicionamento }\end{array}$ & Estudar o mercado & $\begin{array}{l}\text { Formulação das estratégias } \\
\text { básicas }\end{array}$ \\
\hline 4 & & $\begin{array}{l}\text { Definição de objetivos, ações e } \\
\text { priorização de projetos }\end{array}$ & $\begin{array}{l}\text { Surgimento de hipóteses } \\
\text { estratégicas }\end{array}$ & $\begin{array}{l}\text { Definição de objetivos e } \\
\text { direções }\end{array}$ & Definir metas e objetivos & $\begin{array}{l}\text { Implementação das estratégias e } \\
\text { estabelecimento de sistemas de } \\
\text { controle }\end{array}$ \\
\hline 5 & & & $\begin{array}{l}\text { Priorização e consolidação das } \\
\text { estratégias selecionadas }\end{array}$ & $\begin{array}{l}\text { Planejamento de estratégias de } \\
\text { marketing, programas e suporte }\end{array}$ & Estabelecer estratégias & \\
\hline 6 & & & & $\begin{array}{l}\text { Plano para medir progresso e } \\
\text { desempenho }\end{array}$ & Planejar a ação & \\
\hline 7 & & & & $\begin{array}{l}\text { Implementação de controle e } \\
\text { avaliação do plano }\end{array}$ & Controlar as ações & \\
\hline 8 & & & & & & \\
\hline 9 & & & & & & \\
\hline 10 & & & & & & \\
\hline
\end{tabular}

Quadro 1 - Métodos de planejamento e gestão estratégica

Fonte: Elaborado pelo autor. 


\begin{tabular}{|c|c|c|c|c|c|}
\hline 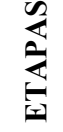 & Kenan, 2006 & Bryson e Alston, 2011 & Farias Filho et al., 2011 & Lambin, 2012 & Senesi, 2013 \\
\hline 1 & Definição da missão do negócio & $\begin{array}{l}\text { Início e consenso a respeito de um } \\
\text { processo de P.E. }\end{array}$ & Declaração da missão institucional & Estabelecimento da missão & Mapeamento e quantificação \\
\hline 2 & Formulação de objetivos & $\begin{array}{l}\text { Esclarecimento dos mandatos } \\
\text { organizacionais }\end{array}$ & Definição de objetivos genéricos & $\begin{array}{l}\text { Análise de atratividade do mercado } \\
\text { (análise externa) }\end{array}$ & $\begin{array}{l}\text { Diagnóstico estratégico participativo } \\
\text { (análise FODA - SWOT) }\end{array}$ \\
\hline 3 & $\begin{array}{l}\text { Análise interna para avaliar recursos } \\
\text { próprios (forças e fraquezas) }\end{array}$ & $\begin{array}{l}\text { Identificação das partes interessadas, } \\
\text { definição de missão, visão e valores }\end{array}$ & Análise do ambiente & $\begin{array}{l}\text { Análise do ambiente competitivo } \\
\text { (análise externa) }\end{array}$ & $\begin{array}{l}\text { Definição dos direcionamentos } \\
\text { estratégicos }\end{array}$ \\
\hline 4 & $\begin{array}{l}\text { Análise externa (ameaças e } \\
\text { oportunidades) }\end{array}$ & Análise ambiental: análise SWOT & $\begin{array}{l}\text { Definição de estratégias deliberadas e } \\
\text { emergentes }\end{array}$ & $\begin{array}{l}\text { Análise da competitividade } \\
\text { organizacional (análise interna) }\end{array}$ & $\begin{array}{l}\text { Formulação de um Projeto de Apoio à } \\
\text { Competitividade (PAC) }\end{array}$ \\
\hline 5 & $\begin{array}{l}\text { Identificação de seleção das } \\
\text { estratégias adequadas }\end{array}$ & $\begin{array}{l}\text { Identificação e enquadramento de } \\
\text { questões estratégicas }\end{array}$ & $\begin{array}{l}\text { Definição de objetivos específicos, } \\
\text { programas de ação e orçamentos }\end{array}$ & Definição de objetivos & \\
\hline 6 & $\begin{array}{l}\text { Implementação e aperfeiçoamento } \\
\text { das estratégias escolhidas }\end{array}$ & Formulação de estratégias & Controle estratégico & \begin{tabular}{|l|} 
Seleção do caminho estratégico \\
\end{tabular} & \\
\hline 7 & & $\begin{array}{l}\text { Revisão e adoção de um plano } \\
\text { estratégico }\end{array}$ & & Desenho do plano de marketing & \\
\hline 8 & & $\begin{array}{l}\text { Estabelecimento de uma efetiva visão } \\
\text { organizacional do futuro }\end{array}$ & & $\begin{array}{l}\text { Análise de vulnerabilidade e planos } \\
\text { de contingência }\end{array}$ & \\
\hline 9 & & $\begin{array}{l}\text { Desenvolvimento deum processo de } \\
\text { implementação efetivo }\end{array}$ & & & \\
\hline 10 & & $\begin{array}{l}\text { Reavaliação das estratégias e do } \\
\text { processo de planejamento estratégico }\end{array}$ & & & \\
\hline
\end{tabular}

Quadro 2- Métodos de planejamento e gestão estratégica

Fonte: Elaborado pelo autor. 


\subsubsection{Borja e Castells (1997) - planejamento estratégico}

Baseados no caso catalão (Barcelona) de planejamento da cidade, os autores foram os responsáveis pela difusão internacional de um modelo de "Planejamento Estratégico de Cidades". A principal justificativa do modelo é dar base econômica, infraestrutura, qualidade de vida, integração social e governabilidade para um território delimitado pela união do setor público e privado.

Os autores propõem que uma visão estratégica do território é fundamental para iniciar projetos multidimensionais de larga escala, e que três condições devem ser satisfeitas:

a. O trabalho de planejamento deve ser relacionado com objetivos baseados nos futuros cenários econômicos, social e cultural.

b. Os projetos e dinâmicas executados nas várias partes do território alvo do planejamento devem estar em coerência.

c. Os projetos devem possuir efeitos metastáticos em todas as áreas do território, impulsionando potenciais ligações entre elas.

Para tanto, o plano estratégico é dividido nas três fases:

1. Definição de metas urbanas

2. Criação e manutenção da dialética entre objetivos, projetos e repercussões

3. Ação de agentes públicos e privados de acordo com as fases estabelecidas de preparação e implementação do plano

\subsubsection{Lopes (1998) - planejamento estratégico}

Em seu livro A Cidade Intencional: o Planejamento Estratégico de Cidades, Lopes (1998) também propõe um método de planejamento estratégico para cidades. Para o autor, a organização inicial do planejamento deve seguir o esquema mostrado na Figura 3, que conta com os envolvidos na organização do plano: 


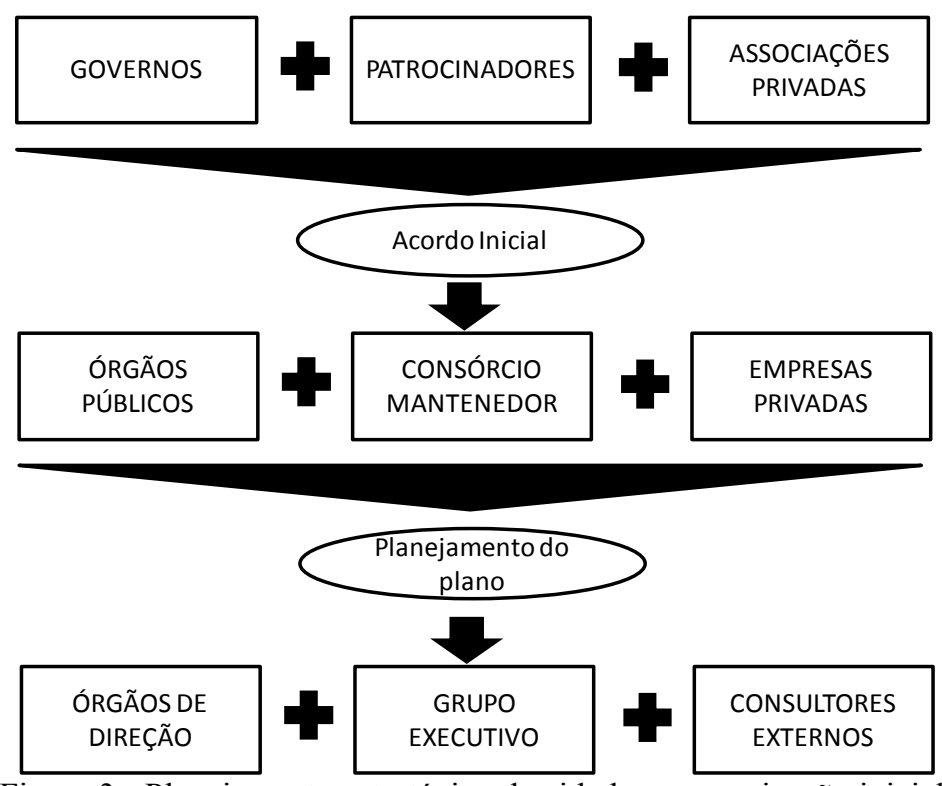

Figura 3 - Planejamento estratégico de cidades - organização inicial Fonte: Adaptado de Lopes (1998, p.116)

As fases efetivas do planejamento proposto podem ser elencadas da seguinte maneira:

\section{Diagnóstico}

Trata do total mapeamento da cidade a qual será implementado o plano. O autor afirma que essa é uma fase crucial no processo e que tão bom será o plano quanto for o trabalho de diagnóstico da cidade.

Ela deve contar com a identificação das oportunidades e ameaças externas (fora do controle da cidade) e das forças e fraquezas internas (sob o controle da cidade).

Lopes (1998) também propõe que nesta etapa sejam elaborados cenários para explorar alternativas futuras do ambiente externo.

A Figura 4 mostra claramente as etapas que devem ser desenvolvidas na fase de diagnóstico: 


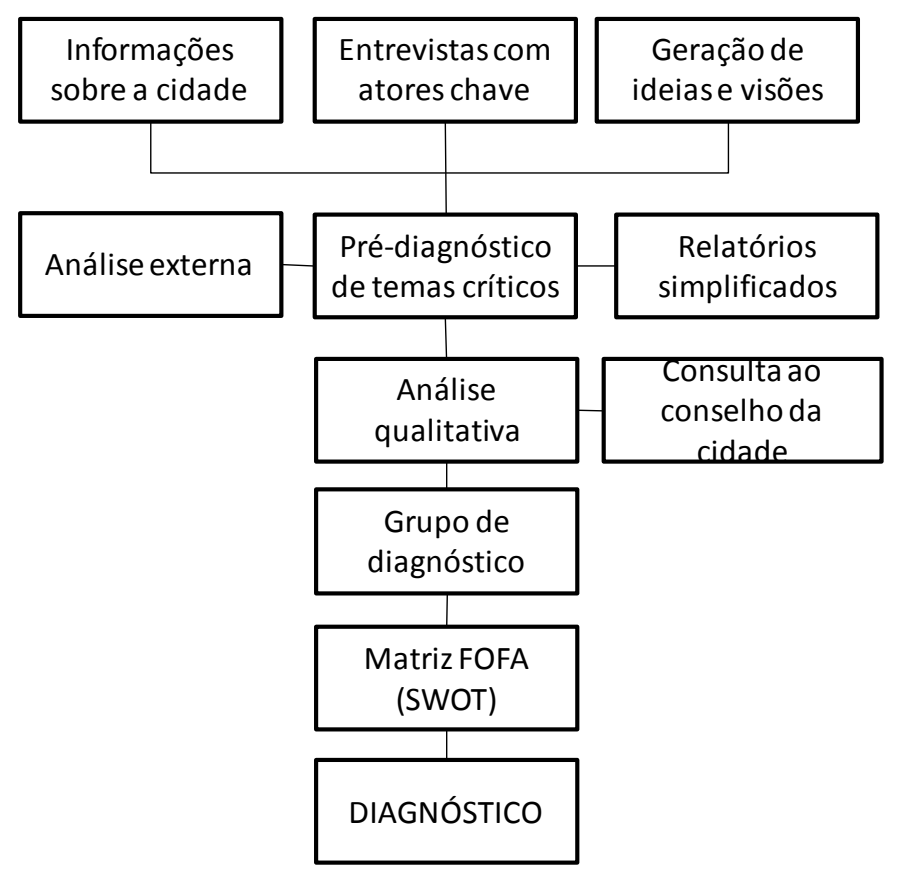

Figura 4 - O processo de diagnóstico Fonte: Adaptado de Lopes (1998, p.136)

\section{Definição de temas críticos a serem analisados}

A partir do diagnóstico da cidade, são identificados os termos críticos nela envolvidos , para que sirvam de direcionamento para as fases seguintes.

\section{Definição de missão e linha de ação estratégica}

A missão neste passo definida deve caracterizar qual a cidade desejada e as linhas de ação dão o direcionamento inicial para satisfazer a missão.

\section{Definição de objetivos, ações e priorização de projetos}

Por meio da linha de ação estratégica são definidos objetivos específicos, ações para chegar a esses objetivos e projetos, que devem ser priorizados de acordo com a necessidade. No momento de definição de objetivos é também é importante definir o que não fazer, ou que deve ser deixado para ser feito em um segundo momento.

\subsubsection{Machado Filho, Marino e Conejero (2003) - gestão estratégica}

Em sua pesquisa, os autores procedem com a aplicação de um método de gestão estratégica no sistema cooperativista agroindustrial brasileiro. Para tanto, eles desenvolvem e executam um método que será descrito a seguir. 
1. Realização de análise de ambiente externo e interno

2. Determinação dos eixos estratégicos

3. Aplicação da ferramenta SWOT

4. Surgimento de hipóteses estratégicas

5. Priorização e consolidação das estratégias selecionadas

Por fim os autores afirmam que o processo exige grande esforço e envolvimento para sua implementação e manutenção.

\subsubsection{Wood (2004) - plano de marketing}

O autor discorre a respeito de um plano de marketing para organizações, em que são propostas sete etapas que podem ser tomadas como base para um planejamento estratégico.

\section{Determinação de missão e analise do ambiente interno e externo}

Nesta etapa, além de determinar a visão da organização, o autor propõe que a análise do ambiente externo seja feita nas bases da PEST, porém sempre considerando como os aspectos levantados com a ferramenta influenciam a habilidade de colocar o plano de marketing em ação e atingir bons resultados.

\section{Pesquisa e análise de mercados e consumidores}

Após analisar a situação atual da organização no ambiente, devem ser avaliados os mercados e consumidores específicos para o negócio. Aspectos como participação de mercado, demandas por produtos, padrões de consumo e satisfação dos clientes.

\section{Determinação da segmentação, alvos e posicionamento}

Wood (2004) afirma que nenhuma organização possui recursos suficientes para atender todos os consumidores em todos os mercados, daí a necessidade da segmentação e posicionamento. Nesta etapa devem ser determinados os segmentos alvo da organização para delimitar sua estratégia de ação.

\section{Definição de objetivos e direções}

Os objetivos do plano devem ser baseados na missão estabelecida e nos macroobjetivos organizacionais. Devem ser separados os objetivos de longo prazo (metas) e os de curto-prazo. A correta delineação e distinção desses dois tipos de objetivos é fundamental para seu sucesso. 


\section{Planejamento de estratégias de marketing, programas e suporte}

Esta etapa consiste no planejamento das estratégias de marketing que serão necessárias para atingir os objetivos. Não deve ser levado em conta apenas como entregar o valor que atenda às necessidades do cliente, mas também como coordenar as ferramentas de marketing voltadas para produto, praça, preço e promoção em um programa individual.

\section{Plano para medir progresso e desempenho}

Esta etapa deve ser conduzida antes da implementação do plano. Devem ser desenvolvidos e documentados orçamentos, previsões, datas e pessoas responsáveis por todo o plano. As previsões do que será alcançado com a aplicação do plano também devem estar claras. Os resultados devem sempre ser acompanhados para observar quão próximo das previsões o plano está chegando.

\section{Implementação, controle e avaliação do plano}

Somente após a implementação do plano será possível saber se ele realmente é efetivo ou não. O resultado final desta fase retroalimenta a primeira fase de planejamento para que o aprendizado organizacional seja contabilizado.

\subsubsection{Barbosa e Brondani (2004) - planejamento estratégico}

Para os autores, existem diversos métodos de planejamento estratégico, sendo que alguns são genéricos e outros possuem direcionamentos para diferentes tipos de organizações. O método de planejamento estratégico proposto por eles é um modelo genérico, que pode ser aplicado nas mais diversas organizações. Barbosa e Brondani (2004) afirmam que existem diversas maneiras de se realizar um planejamento estratégico, e mediante uma revisão dessas maneiras propõem seus próprios passos, que são:

\section{Entendimento da organização}

Antes de se iniciar um planejamento estratégico, os autores acreditam ser fundamental que a organização adquira uma visão clara da sua atual situação. Para tanto, questões como "Quem somos?”, “Onde queremos chegar?”, “Avaliamos os fatores externos?" e "Como atingiremos nossos objetivos?" devem ser genericamente respondidas. 


\section{Definir a missão}

Depois de concluída a primeira fase de entendimento, a missão da organização deve ser definida. Essa missão deve definir claramente o que a empresa faz e como a empresa faz, caracterizando a razão de sua existência.

\section{Identificar fatores fundamentais para obter sucesso}

Nesta etapa deve ocorrer o levantamento de documentos e relatórios e estudo dos principais fatores influenciadores de desempenho na organização. Após identificação, os fatores devem ser monitorados, para que a empresa tenha sobre eles certo controle.

\section{Estudar o mercado}

Este item é fundamental para o entendimento de como a organização está posicionada no seu mercado. Devem ser avaliadas as suas relações com compradores, fornecedores e concorrentes, bem como qual a participação da organização em seu mercado alvo.

\section{Definir metas e objetivos}

De acordo com as potencialidades e limitações da organização, identificados nos passos anteriores, metas e objetivos devem ser traçados. Eles serão o guia da execução das ações posteriores.

\section{Estabelecer estratégias}

A partir de todas as informações anteriores e das reais necessidades encontradas na organização alvo, são estabelecidas estratégias que, na sua execução, objetivam sanar as lacunas encontradas criando vantagens competitivas.

\section{Planejar a ação}

Tendo as estratégias definidas, esta etapa é responsável pelo planejamento de sua implementação. Devem ser definidos aspectos como quem serão os responsáveis por cada ação, quais serão os prazos, como os orçamentos serão alocados, entre outros.

\section{Controlar as ações}

O controle das ações é fundamental para a avaliação do desempenho versus investimento. Caso o desempenho de uma ação não esteja sendo condizente com as expectativas da organização, mudanças devem ser realizadas e novas ações devem ser delineadas Esta fase é responsável basicamente pela identificação de possíveis falhas. 


\subsubsection{Harrison (2005) - gestão estratégica}

Em seu livro Administração Estratégica de Recursos e Relacionamentos, Harrison propõe uma estrutura de administração estratégica. Ela é composta pelas seguintes etapas:

1- $\quad$ Análise do ambiente, dos públicos interessados e dos recursos organizacionais;

2- $\quad$ Estabelecimento da direção estratégica;

3- $\quad$ Formulação das estratégias básicas;

4- Implementação das estratégias e estabelecimento de sistemas de controle.

\subsubsection{Kenan (2006) - gestão estratégica}

Em seu artigo, o autor procede com a aplicação de um método de gestão estratégica no setor de agronegócios da Turquia. Propõe uma sequência de seis passos, sendo que o primeiro é a definição da missão do setor, porém na aplicação a sequência proposta não é mantida, sendo que a missão é definida posteriormente à análise de ambientes e definição das estratégias.

Inicialmente é conduzida a análise de ambiente. Após realizada, Kenan (2006) procede com uma matriz SWOT, de onde emergem as estratégias a serem utilizadas a partir do cruzamento dos pontos fortes, fracos das ameaças e das oportunidades. Uma vez definidas as estratégias, estas são cruzadas para se chegar à missão do setor. Por fim, a partir das estratégias e da missão determinadas, o plano de ação deve ser determinado. $\mathrm{O}$ autor finaliza afirmando que a gestão estratégica é uma atividade de atualização contínua.

\subsubsection{Bryson e Alston (2011) - planejamento estratégico}

Os autores descrevem em sua obra um método de planejamento estratégico direcionado para instituições públicas e sem fins lucrativos. Em se tratando de órgãos públicos, grande destaque é dado aos stakeholders (partes interessadas) envolvidos no processo, pois sem eles, a organização perde sua força. 


\section{Início e consenso a respeito de um processo de planejamento estratégico.}

\section{Esclarecimento dos mandatos organizacionais}

Nesta etapa, devem ser esclarecidos os mandatos formais e informais da organização para, dessa forma, deixar claro seus deveres e explorar suais implicações nas ações organizacionais.

\section{Identificação das partes interessadas, definição de missão, visão e valores}

Nesta etapa, um ponto de grande importância para a execução de um planejamento estratégico de organizações públicas e sem fins lucrativos é a identificação das partes interessadas no plano. Os autores afirmam que, para o sucesso de uma organização dessa natureza, é primordial identificar e suprir os interesses e desejos das principais partes interessadas (stakeholders), bem como ir ao encontro das necessidades sociais e políticas presentes.

A partir das demandas descritas acima devem ser definidas a missão, visão e valores.

\section{Análise ambiental: análise SWOT}

Nesta etapa, tão importante quanto identificar as forças, fraquezas, ameaças e oportunidades da organização, é a identificação de suas implicações estratégicas.

\section{Identificação e enquadramento de questões estratégicas}

Os primeiros quatro passos do método dão base para este quinto passo. São então identificados os principais desafios estratégicos que afetam a organização, podendo estes estar relacionados às áreas de missão e valores, mix de produtos ou serviços, custos, financeira, de processo ou de gerenciamento e administração.

\section{Formulação de estratégias}

As estratégias devem ser desenvolvidas a fim de lidar com as questões identificadas no item cinco. Bryson e Alston (2011) propõem quatro diferentes abrangências estratégicas que podem ser adotadas:

- Uma grande estratégia para toda a organização como um todo;

- Estratégias para subunidades da organização;

- Estratégias para um ou mais programas, serviços, produtos, projetos ou processos do negócio;

- Estratégias para uma ou mais função como, por exemplo, recursos humanos, informação e tecnologias, finanças e compras.

\section{Revisão e adoção de um plano estratégico}

A partir desta etapa, o método apresenta um caráter menos prático e mais gerencial. 
Esta etapa deve ser utilizada para formalizar o plano, ou seja, juntar todas as informações discutidas nos passos anteriores para chegar ao passo de implementação do plano propriamente dito.

\section{Estabelecimento de uma efetiva visão organizacional do futuro}

Nesta etapa é determinada uma visão do futuro da organização caso as estratégias delineadas, bem como a implementação do plano estratégico, obtenham sucesso. Essa fase é muito importante, pois a partir dela os colaboradores passam a ver com clareza os seus papéis na execução do plano e outras partes interessadas (diferentes daquelas já envolvidas com a organização) podem passar a se interessar e atuar como futuros incentivadores da organização.

Vale lembrar que nem todas as organizações atingirão o posicionamento inicial almejado, porém quanto mais madura estrategicamente uma organização for, mais próxima desse posicionamento ela ficará. Os autores afirmam que a determinação dessa visão de futuro serve mais como um guia para a implementação estratégica do que para a formulação de estratégias.

\section{Desenvolvimento de um processo de implementação efetivo}

Neste momento, é desenvolvido o plano de ação e os processos efetivos de implementação. Quanto mais a formulação de estratégias estiver alinhada com os meios de implementação disponíveis, maior será o sucesso final do processo.

\section{Reavaliação das estratégias e do processo de planejamento estratégico}

Este estágio serve para identificar, pelo monitoramento, o que está funcionando no plano, o que não está e mudar o que for necessário, para que os problemas não sejam identificados somente ao final do processo.

\subsubsection{Farias Filho et al. (2011) - planejamento estratégico}

Em seu trabalho, os autores realizaram o planejamento estratégico de uma universidade particular do Pará, na busca de desenvolver estratégias para potencializar suas forças e capturar as oportunidades de melhoria presentes no ambiente externo. As etapas desenvolvidas foram: 


\section{Declaração da missão institucional}

A missão institucional aqui definida deve estar de acordo com o propósito máximo da organização. A ampla disseminação interna e externa da missão é parte fundamental para sua perpetuação.

\section{Definição de objetivos genéricos}

Nesta etapa, são definidos macro objetivos que estejam de acordo com a missão já definida. Com os objetivos genéricos, são estabelecidas suas medidas quantitativas, as chamas metas de execução, que também envolvem os prazos determinados, as medidas de avaliação e os responsáveis.

\section{Análise do ambiente}

Esta etapa conta com a análise de pontos fortes e fracos relacionados ao ambiente interno, bem como a avaliação de aspectos relativos ao ambiente externo a partir da análise SWOT.

\section{Definição de estratégias deliberadas e emergentes}

As estratégias são definidas a partir dos objetivos propostos em fases anteriores. Elas devem levar em conta a situação interna e externa da organização e também possuem responsáveis e prazos de execução.

\section{Definição de objetivos específicos, programas de ação e orçamento}

Esta etapa conta com o desdobramento de das estratégias em planos táticos de atuação com especificação de recursos.

\section{Controle estratégico}

Diz respeito a fase de acompanhamento dos planos estratégicos. A partir de ações relacionadas a esta etapa, os planos são corrigidos e melhorados de acordo com a necessidade e surgimento de novas oportunidades.

Apesar de algumas diferenças com relação a outros planos estudados, Farias Filho et al. (2011) finalizam afirmando que a implementação do planejamento estratégico na universidade estudada vem contribuindo fortemente para a sua manutenção no mercado, bem como para o estabelecimento de metas e busca de um futuro desejado. 


\subsubsection{Lambin (2012) - planejamento estratégico}

O autor propõe um método de planejamento estratégico para organizações em geral, porém seu método é muito bem detalhado, contendo as ferramentas utilizadas em cada fase. Um aspecto positivo do método proposto por Lambin (2012) é que, dentro de cada etapa, são sugeridos diversos questionários que, quando respondidos, propiciam os principais direcionamentos da etapa em questão. A seguir, serão descritos os passos de um método de planejamento estratégico proposto pelo autor. Algumas das suas especificidades serão destacadas.

\section{Estabelecimento da missão}

Para o autor, além dos conceitos básicos envolvidos em um missão, a sua definição deve levar em conta: a história da organização; a definição de negócio; os objetivos e restrições corporativas; a escolha de estratégias básicas.

\section{Análise de atratividade do mercado (análise externa)}

Nesta etapa, algumas análises fundamentais devem ser realizadas. Entre elas:

- análise de tendências de mercado;

- análise do comportamento do consumidor;

- análise da estrutura de distribuição;

\section{Análise do ambiente competitivo (análise externa)}

- análise do ambiente competitivo;

- análise das tendências macro-ambientais;

\section{Análise da competitividade organizacional (análise interna)}

Passando para o ambiente interno da organização, uma análise detalhada da sua competitividade deve ser realizada. Essa análise também é conhecida como a análise das forças e fraquezas da organização. Para tanto, são destacados alguns pontos fundamentais:

- situação atual do marketing da organização (análise de portfólio);

- análise dos principais competidores da organização;

- análise da penetração da distribuição da organização;

- análise dos programas de comunicação;

- análise das políticas de preço adotadas; 


\section{Definição de objetivos}

Nesta etapa, são detalhadas as principais áreas de interesse as quais os objetivos devem estar alinhados. São elas:

- objetivos voltados para vendas;

- objetivos voltados para lucros;

- objetivos voltados aos clientes;

- objetivos voltados para participação de mercado;

- objetivos de integração;

\section{Seleção do caminho estratégico}

Para o autor, deve-se fazer grande distinção entre a definição dos objetivos e a maneira que será utilizada para alcançá-los. Para tanto, é necessário definir as estratégias que serão utilizadas para atingir os objetivos propostos. $\mathrm{O}$ autor elenca algumas das principais vertentes estratégicas que podem ser seguidas:

- estratégia de defesa;

- estratégia de penetração de mercado;

- estratégia de desenvolvimento de novos mercados;

- estratégia de extensão das linhas de produto já existentes;

- estratégia de desenvolvimento internacional;

\section{Desenho do plano de marketing}

O plano de marketing é visto aqui como o plano de ação utilizado para colocar em prática as estratégias escolhidas. Além do detalhamento das ações a serem tomadas, nesta etapa devem ser detalhadas as condições financeiras do plano, os orçamentos, o cronograma de ação e os responsáveis por cada ação. De maneira geral, pode-se falar que são identificados e alocados os recursos humanos e financeiros.

\section{Análise de vulnerabilidade e planos de contingência}

Esta etapa é fundamental para a validação do plano proposto. São feitos testes de robustez do plano e propostos planos de contingência. Dessa forma, e com a avaliação de riscos e controle, se a organização tiver que enfrentar uma nova situação inesperada, ela já estará preparada, com a disponibilidade de planos alternativos.

Os métodos de planejamento estratégico aqui revisados são desenhados e direcionados para aplicação em diversas organizações com objetivos próprios.

O presente trabalho busca reunir métodos aplicados a vários agentes da economia, desenvolvendo algo mais abrangente, que vai além do planejamento de uma única empresa, 
pois busca todos os envolvidos em um sistema agroindustrial em prol do desenvolvimento conjunto da cadeia produtiva que constitui a base desse sistema.

\subsubsection{Senesi (2013) - planejamento estratégico}

O plano estratégico explicitado por Senesi (2013) faz parte do Processo de Mudança e Dinamização do setor de Oleaginosas do Uruguai (SAGOU) que é desenvolvido dentro de um programa governamental para aumento da competitividade de clusters e cadeias produtivas do Uruguai.

O plano consta de quatro etapas básicas:

\section{Mapeamento e quantificação}

\section{Diagnóstico estratégico participativo (análise - SWOT)}

Nesta etapa, é realizada uma análise dos pontos fortes e fracos internos da cadeia de oleaginosas do país e das ameaças e oportunidades do ambiente externo.

A diferença entre outras análises e esta, realizada neste plano, é que nesta são pré-definidos aspectos dentro de cada dimensão a ser avaliada e então são dadas notas para cada aspecto (dentro das forças, fraquezas, oportunidades e ameaças). Ao fim, tem-se uma pontuação quantitativa da análise no setor, que vai especificar quais são as ameaças mais importantes, as forças mais relevantes do setor, as fraquezas mais impactantes e as principais oportunidades.

\section{Definição dos direcionamentos estratégicos}

Os direcionamentos estratégicos são tomados a partir da análise anterior, porém estão delimitados dentro dos seguintes temas:

- Desenvolvimento do cluster

- Ambiente institucional

- Infraestrutura, organizações e empresas do setor

- Comunicação

- Comercialização

- Recursos humanos

- Investigação, desenvolvimento e extensão

- Desenvolvimento tecnológico 


\section{Formulação de um Projeto de Apoio à Competitividade (PAC)}

A formulação dos projetos estratégicos é realizada baseada nos mesmos temas dos direcionamentos estratégicos, porém com ainda mais desdobramentos internos.

\subsection{O método GESis de planejamento e gestão estratégica de cadeias produtivas}

Esta seção faz uma revisão do método de Gestão Estratégica de Sistemas Agroindustriais (GESis) proposto por Neves (2008) que foi adaptado para aplicação nas cadeias produtivas do estado de Goiás. No capítulo seguinte, serão detalhadas as adaptações realizadas para aplicação nos estudos de caso, bem como os objetivos de cada adaptação.

O método aqui presente foi resultado de uma demanda do SAG da laranja no Brasil no ano de 2004. Após o desenvolvimento do método para essa primeira cadeia, ele foi aperfeiçoado por meio da sua aplicação empírica em outros SAGs, como o do trigo (2005) e do leite (2007) no Brasil, do trigo no Uruguai (2007) e do leite na Argentina (2007). Cinco etapas fundamentais estruturam o método original. Cada etapa contém fases específicas que devem ser realizadas para chegar ao seu objetivo proposto. A figura 5 mostra as cinco etapas.

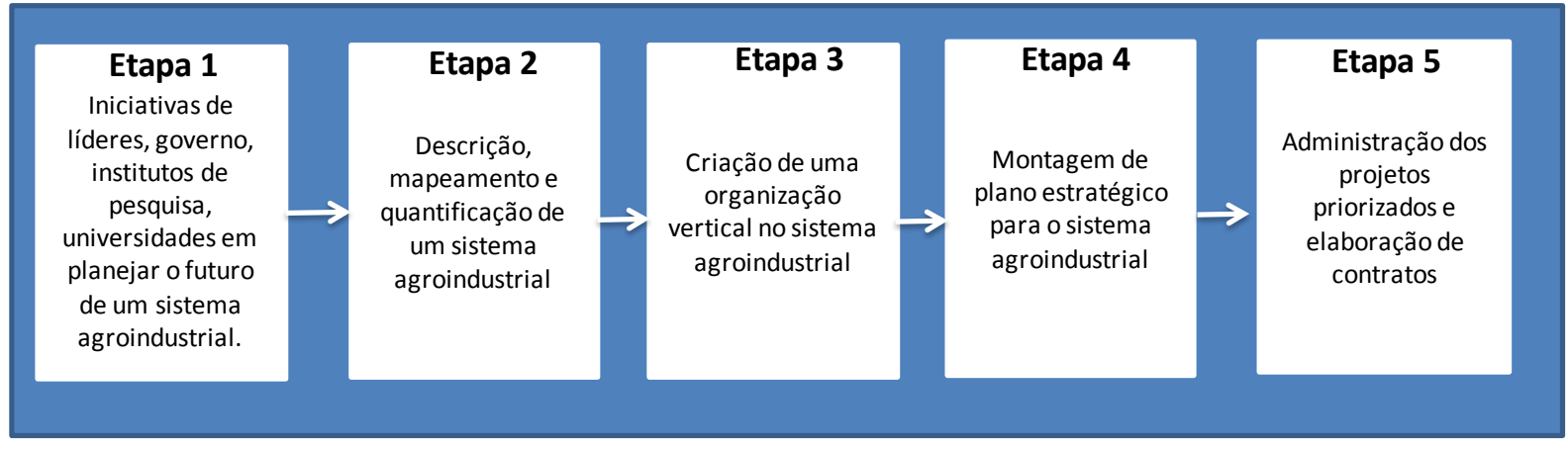

Figura 5- Método proposto para planejamento e gestão estratégica de sistemas agroindustriais. Fonte: Neves (2008)

\subsection{1 - ETAPA 1: Iniciativas de líderes, governo, institutos de pesquisa e universidades em planejar o futuro de suas cadeias produtivas.}

Um sistema agroindustrial é algo muito abrangente e complexo. Para que o método GESis seja aplicado de maneira coerente e efetiva, muitos agentes devem estar envolvidos 
uma vez que os esforços e a mobilização de pessoas deve ser coletiva. Devido a isso, a iniciativa da execução do método deve partir de alguma organização existente no setor que tenha força suficiente para reunir o pessoal adequado agindo como facilitador do processo. A iniciativa pode vir de alguma organização setorial em conjunto com o governo, universidades e institutos de pesquisa, bem como das chamadas câmaras setoriais.

\subsection{2 - ETAPA 2: Descrição, mapeamento e quantificação do sistema agroindustrial.}

A descrição, mapeamento e quantificação do sistema que o método será aplicado é importante, pois identifica todos os agentes envolvidos e mostra a importância econômica de cada agente para a cadeia, aumentando a credibilidade do método.

Esta etapa conta com seis fases que facilitam sua execução. A figura 6 mostra as fases que devem ser executadas nesta etapa para a obtenção do resultado esperado.

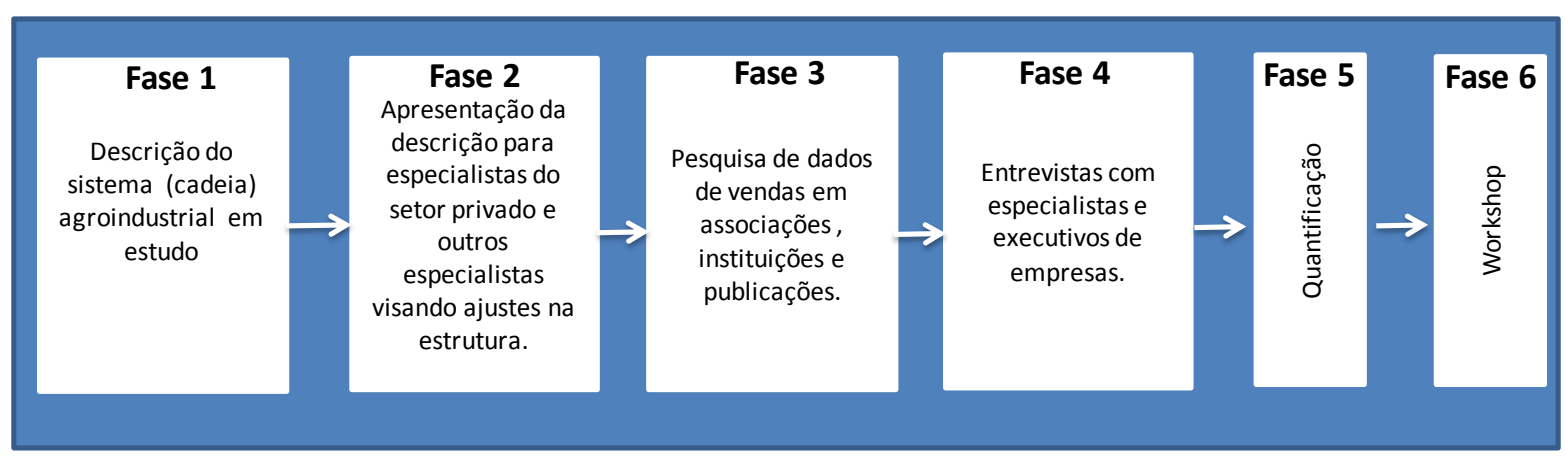

Figura 6 - Método utilizado para caracterizar e quantificar sistemas agroindustriais. Fonte: Neves (2008)

\subsubsection{ETAPA 3: Criação de uma organização vertical no sistema agroindustrial}

Esta etapa busca solucionar o problema de desorganização encontrado em muitos SAGs. Neves (2008) afirma que a maioria dos SAGs possuem organizações horizontais, que agregam uma mesma classe dentro de uma cadeia (fazendeiros, indústria, varejo etc.), mas que é grande a dificuldade de encontrar uma organização vertical que agregue todos os elos da cadeia lutando por um objetivo comum. 
A criação de uma organização vertical para o possível SAG objeto da implementação do método tem como objetivos: a organização das informações existentes entre os elos e a troca de informações; a discussão conjunta das estratégias, buscando um objetivo comum para a cadeia; e o fortalecimento de uma voz única para articulação com as instituições. A organização vertical criada deve ter flexibilidade para captar e usar os recursos disponíveis.

\subsubsection{ETAPA 4: Montagem do plano estratégico para o sistema agroindustrial.}

Neves (2008) propõe que para a realização do plano estratégico do SAG em questão são necessários 12 passos que serão mostrados a seguir. A Figura 7 ilustra os 12 passos propostos para a criação do plano estratégico.

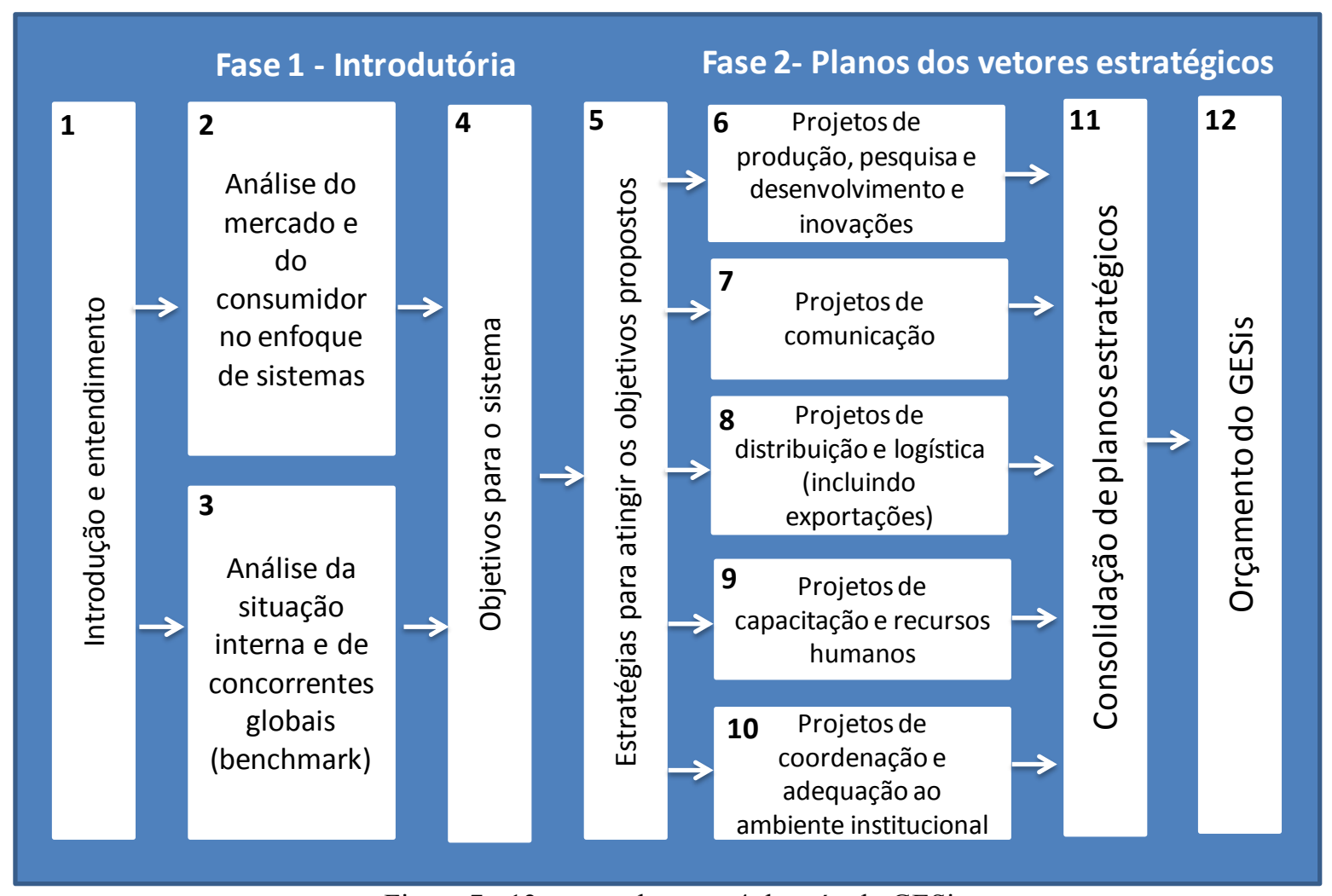

Figura 7 - 12 passos da etapa 4 do método GESis.

Fonte: Neves (2008, p.337)

O Quadro 3 a seguir mostra quais ações devem ser realizadas em cada passo. 
Quadro 3 - Planejamento e gestão estratégica para sistemas agroindustriais - sequencia detalhada dos passos propostos.

\begin{tabular}{|c|c|}
\hline $\begin{array}{l}\text { 1. Introdução e } \\
\text { entendimento }\end{array}$ & $\begin{array}{l}\text { - Verificar se o sistema tem outros planos feitos e estudá-los } \\
\text { - Verificar como é o método de planejamento de sistema que está sendo estudado } \\
\text { - Verificar quais equipes participarão do processo } \\
\text { - Buscar planos feitos para sistemas agroindustriais em outros países, para benchmark. } \\
\text { - Verificar que pessoa da equipe pode ser um promotor do relacionamento com outros } \\
\text { sistemas. } \\
\text { - Verificar, em casos de sistemas com processos de planejamento sofisticados, como o } \\
\text { modelo GESis pode ajudar o modelo existente, adaptando-o, gradualmente, ao sistema } \\
\text { proposto. }\end{array}$ \\
\hline $\begin{array}{l}\text { 2. Análise do } \\
\text { mercado e do } \\
\text { consumidor no } \\
\text { enfoque de } \\
\text { sistemas }\end{array}$ & $\begin{array}{l}\text { - Levantar as ameaças e oportunidades advindas das chamadas variáveis incontroláveis } \\
\text { (possíveis mudanças nos ambientes político/legal, econômico e natural, sociocultural e } \\
\text { tecnológico), tanto no mercado nacional como no internacional. } \\
\text { - Entender as barreiras (tarifárias e não-tarifárias) existentes e verificar ações coletivas } \\
\text { para sua redução. } \\
\text { - Analisar o comportamento dos consumidores final e intermediário (distribuidores) e } \\
\text { seus processos de decisão de compra. } \\
\text { - Analisar as oportunidades para a adequação ao meio ambiente, ao comércio justo, à } \\
\text { sustentabilidade e aos objetivos de desenvolvimento sustentável. } \\
\text { - Analisar as oportunidades para a adequação aos ambientes institucionais trabalhistas } \\
\text { nacional e internacional. } \\
\text { - Montar um Sistema de Informações para que o sistema possa estar sempre informado e } \\
\text { tomando decisões com suporte e embasamento. } \\
\text { - Descrever os principais concorrentes nacionais e internacionais. }\end{array}$ \\
\hline $\begin{array}{l}\text { 3. Análise da } \\
\text { situação interna e } \\
\text { de concorrentes } \\
\text { globais } \\
\text { (benchmark) }\end{array}$ & $\begin{array}{l}\text { - Levantar todos os pontos fortes e fracos do sistema. } \\
\text { - Mapeamento dos contratos e das formas de coordenação existentes. } \\
\text { - Descrever as estruturas de governança existentes, com as características das transações. } \\
\text { - Fazer essa análise também de seus principais concorrentes. } \\
\text { - Analisar a criação de valor, os recursos e as competências do sistema. } \\
\text { - Analisar os fatores críticos de sucesso do sistema. } \\
\text { - Selecionar dentre os sistemas (que podem ou não ser concorrentes) quais, e em que } \\
\text { áreas, serão benchmark (fontes de boas ideias). }\end{array}$ \\
\hline $\begin{array}{l}\text { 4. Objetivos para } \\
\text { o sistema }\end{array}$ & $\begin{array}{l}\text { - Definir e quantificar os principais objetivos em termos de produção, exportação, } \\
\text { importação e vendas, visando ao crescimento sustentável e à solução dos pontos } \\
\text { colocados como fracos. }\end{array}$ \\
\hline $\begin{array}{l}\text { 5. Estratégias } \\
\text { para atingir os } \\
\text { objetivos } \\
\text { propostos }\end{array}$ & $\begin{array}{l}\text { - Listar as principais estratégias (ações) que serão usadas para atingir os objetivos } \\
\text { propostos no passo } 4 \text {, em termos de posicionamento, exportação, captura de valor e } \\
\text { segmentação de mercado. }\end{array}$ \\
\hline $\begin{array}{l}\text { 6. Projetos de } \\
\text { produção, } \\
\text { pesquisa e } \\
\text { desenvolvimento e } \\
\text { inovação }\end{array}$ & $\begin{array}{l}\text { - Analisar os potenciais produtivos e as capacidades de produção. } \\
\text { - Mapear e planejar os riscos em produção (sanitários e outros). } \\
\text { - Analisar os produtos e as linhas de produtos, bem como as linhas de produtos } \\
\text { complementares para decisões de expansão. } \\
\text { - Levantar as oportunidades de inovações no sistema agroindustrial, lançamento de novos } \\
\text { produtos. } \\
\text { - Levantar as oportunidades de montagem de redes de inovação nacionais e } \\
\text { internacionais. } \\
\text { - Verificar parcerias com universidades e com a área médica. } \\
\text { - Detalhar todos os serviços que estão sendo e que serão oferecidos. } \\
\text { - Tomar decisões com relação à construção de marcas conjuntas e aos selos de uso do } \\
\text { sistema. } \\
\text { - Analisar e implementar os processos de certificação do sistema agroindustrial. } \\
\text { - Adequar os produtos às normas e ao ambiente institucional. } \\
\text { - Verificar a sustentabilidade ambiental. } \\
\text { - Tomar decisões com relação às embalagens (rótulos, materiais, design). }\end{array}$ \\
\hline
\end{tabular}




\begin{tabular}{|c|c|}
\hline & Orçar os investimentos decorrentes desta etapa. \\
\hline $\begin{array}{l}\text { 7. Projetos de } \\
\text { comunicação }\end{array}$ & $\begin{array}{l}\text { - Identificar o público-alvo que receberá a comunicação (mensagens do sistema } \\
\text { agroindustrial). } \\
\text { - Desenvolver os objetivos desejados para essa comunicação (conhecimento de produto, } \\
\text { lembrança de produto, persuasão, entre outros); tentar atingir posicionamento e } \\
\text { mensagem únicos dos produtos gerados pelo sistema. } \\
\text { - Definir o composto de comunicação que será utilizado, ou seja, definir os planos de } \\
\text { propaganda, de relações públicas e publicidade, de promoção de vendas, entre outros. } \\
\text { - Fazer benchmark de filmes e materiais internacionais usados por outros sistemas } \\
\text { agroindustriais. } \\
\text { - Orçar as ações de comunicação e, possivelmente, determinar a verba promocional anual } \\
\text { envolvendo todos os agentes da rede. } \\
\text { - Indicar como os resultados das comunicações serão medidos, para que o sistema } \\
\text { aprenda cada vez mais a usar as melhores ferramentas e obtenha retorno dos } \\
\text { investimentos. }\end{array}$ \\
\hline $\begin{array}{l}\text { 8. Projetos de } \\
\text { distribuição e } \\
\text { logística }\end{array}$ & $\begin{array}{l}\text { - Analisar os canais de distribuição dos produtos e buscar novos, definindo objetivos de } \\
\text { distribuição, como presença em mercados, tipo e número de pontos-de-venda, serviços a } \\
\text { serem oferecidos, informações de mercado, promoção de produtos e incentivos. } \\
\text { - Analisar as possibilidades de captura de valor em canais de distribuição. } \\
\text { - Identificar os possíveis desejos dos distribuidores internacionais e do consumidor para } \\
\text { adequar os serviços prestados. } \\
\text { - Definir o modo de entrada nos mercados, se será via franquias, via joint ventures ou } \\
\text { vias outras formas contratuais ou, até mesmo, via integração vertical. } \\
\text { - Determinar o orçamento anual para a distribuição. } \\
\text { - Verificar como ações de distribuição podem ser feitas em conjunto com outros } \\
\text { sistemas. }\end{array}$ \\
\hline $\begin{array}{l}\text { de } \\
\text { e } \\
\text { Imanos }\end{array}$ & $\begin{array}{l}\text { - Definir o treinamento em gestão para o sistema agroindustrial. } \\
\text { - Definir o treinamento técnico da mão-de-obra, em controle de custos, para o uso de } \\
\text { tecnologias. } \\
\text { - Definir o treinamento em comercialização nacional e internacional. } \\
\text { - Definir a transmissão e o acesso às informações dos centros tecnológicos e de pesquisa. } \\
\text { - Definir o treinamento em produção de alimentos. } \\
\text { - Definir a melhoria da assistência técnica nas propriedades. } \\
\text { - Outros. }\end{array}$ \\
\hline $\begin{array}{l}\text { 10. Projetos de } \\
\text { coordenação e } \\
\text { adequação ao } \\
\text { ambiente } \\
\text { institucional }\end{array}$ & $\begin{array}{l}\text { - Elaborar projeto de redução da burocracia para a obtenção de crédito. } \\
\text { - Elaborar projetos de melhoria da infraestrutura básica. } \\
\text { - Elaborar projeto para a homogeneização de tributos e incentivos. } \\
\text { - Elaborar projeto para o aumento no consumo de programas governamentais. } \\
\text { - Elaborar programa para o isolamento de áreas produtivas. } \\
\text { - Elaborar projeto para a redução de tributos no sistema agroindustrial. } \\
\text { - Elaborar projeto para o fortalecimento da atividade exportadora via Agência Brasileira } \\
\text { de Promoção de Exportação e Investimentos (Apex). } \\
\text { - Verificar leis para incentivo ao uso das tecnologias (incentivo fiscal etc.). } \\
\text { - Elaborar projeto para a padronização de produtos e nomes de produtos. } \\
\text { - Elaborar projetos para maior transparência nas legislações referentes a produtos e } \\
\text { processos. } \\
\text { - Elaborar propostas de sistemas de solução de conflitos. } \\
\text { - Elaborar propostas de coordenação e contratos. }\end{array}$ \\
\hline $\begin{array}{l}\text { 11. Consolidação } \\
\text { de planos } \\
\text { estratégicos }\end{array}$ & - Consolidar todos os projetos gerados nos passos de 6 a 10 e definir as prioridades \\
\hline $\begin{array}{l}\text { 12. Orçamento d } \\
\text { GESis }\end{array}$ & mentos dos projetos que trazem custos e 0 \\
\hline
\end{tabular}

Fonte: Adaptado de Neves (2008). 


\subsubsection{ETAPA 5: Administração dos projetos priorizados e elaboração de contratos}

Esta etapa diz respeito ao acompanhamento dos projetos que devem emergir da Etapa 4 do método. Neste momento, devem ser analisados e descritos os objetivos e ações, descritas as sugestões de implementação, indicadores de desempenho, projetos e planos relacionados, delineadas as inter-relações, equipes, prazos, orçamentos e formas de gestão.

Nesta etapa, também devem ser desenhados os contratos entre as partes participantes de cada projeto.

Neves (2008, p.341) afirma que "[...]por ser um modelo ainda teórico, deve existir prudência em sua aplicação; assim ele deve passar por rigoroso e criterioso teste empírico para a sua validação."

Dentre as vantagens encontradas na aplicação do método GESis em sistemas agroindustriais estão a orientação de uma visão futura para aquela cadeia produtiva, o compartilhamento de informações e experiências entre os agentes, a coordenação do sistema agroindustrial, o aumento da flexibilidade do sistema frente a mudanças inesperadas, a gestão coletiva mais rigorosa e profissional e o melhor posicionamento do sistema agroindustrial estudado (NEVES, 2008).

\subsection{O método GESis adaptado e suas principais alterações}

Este capítulo descreve o método GESis adaptado, que foi aplicado nos casos alvo deste trabalho (Planejamentos e Gestão Estratégica das cadeias produtivas do estado de Goiás). Nesta etapa são evidenciados os passos do método original que fizeram parte da nova aplicação, aqueles que não foram relevantes para sua gestão estratégica e os novos passos e novas ferramentas que foram introduzidos no método original para se chegar a um resultado satisfatório.

A apresentação se dará na mesma ordem daquela encontrada no método GESis, apenas com comentários a respeito das mudanças.

Como visto no capítulo anterior, o método GESis, como proposto por Neves (2008), é composto por cinco etapas principais. A Figura 8 ilustra essas cinco etapas. 


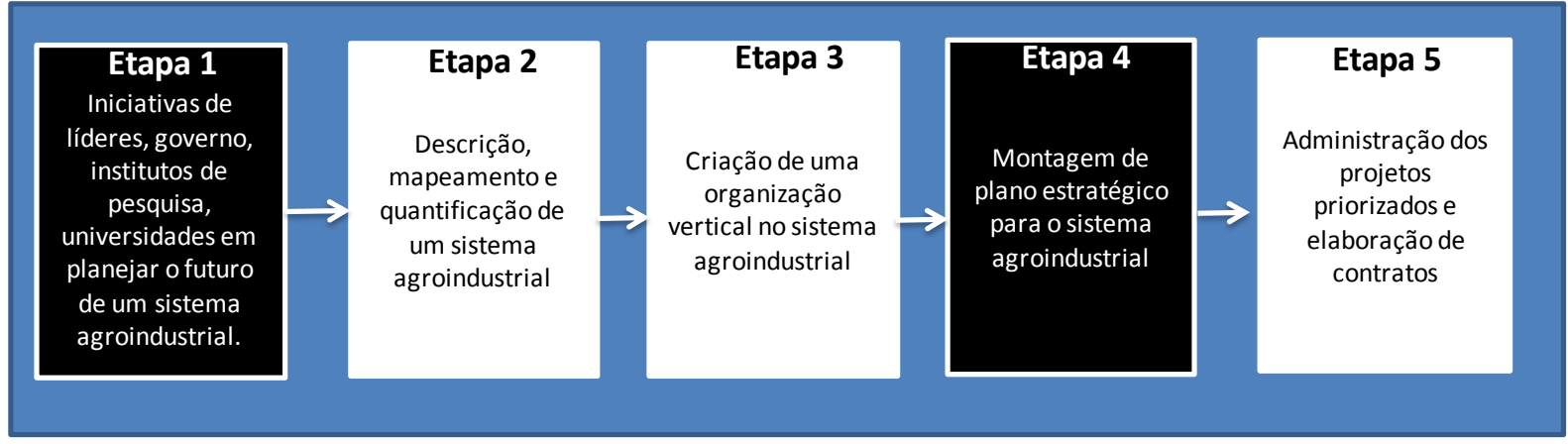

Figura 8 - Método GESis - Planejamento e Gestão Estratégica de Sistemas Agroindustriais. Fonte: Adaptado de Neves (2008).

A primeira etapa, que caracteriza o ponto de partida do estudo, deve contar obrigatoriamente com a participação efetiva de alguma organização setorial que, em conjunto com governo, universidades e institutos de pesquisa, articula o projeto na busca de planejar e fornecer uma visão de futuro para os sistemas agroindustriais desejados. O presente trabalho foi resultado da necessidade de planejar estrategicamente o agronegócio do estado de Goiás, observada pela Federação das Indústrias do Estado de Goiás (FIEG). Esta organização setorial elegeu um conjunto de cadeias produtivas e agregou parceiros estratégicos, agindo como agente facilitador para a realização do trabalho.

$\mathrm{Na}$ sequência, o método conta com mais quatro etapas, sendo que a segunda é referente ao mapeamento e à quantificação das cadeias produtivas envolvidas, a terceira propõe a criação de uma organização vertical, a quarta refere-se efetivamente ao método de gestão estratégica e a última conta com a implementação e monitoramento das ações estratégicas propostas.

Como a adaptação foi feita para criar um método de gestão estratégica para o estado de Goiás, o trabalho foi restrito às etapas 1 e 4 do método.

A etapa 4 (principal foco dos estudos de caso) tem como finalidade específica definir os objetivos estratégicos dos SAGs e as estratégias e planos que possibilitarão o alcance desses objetivos. A adaptação do método GESis original (NEVES, 2008) que foi aplicada no estado de Goiás, conta com 15 passos na etapa 4 (Figura 12). O método original conta com apenas doze etapas e a principal mudança está na inserção de mais três vetores estratégicos no método adaptado (etapas 11, 12 e 13).

A Figura 9 a seguir mostra as etapas que foram inseridas no método adaptado. 


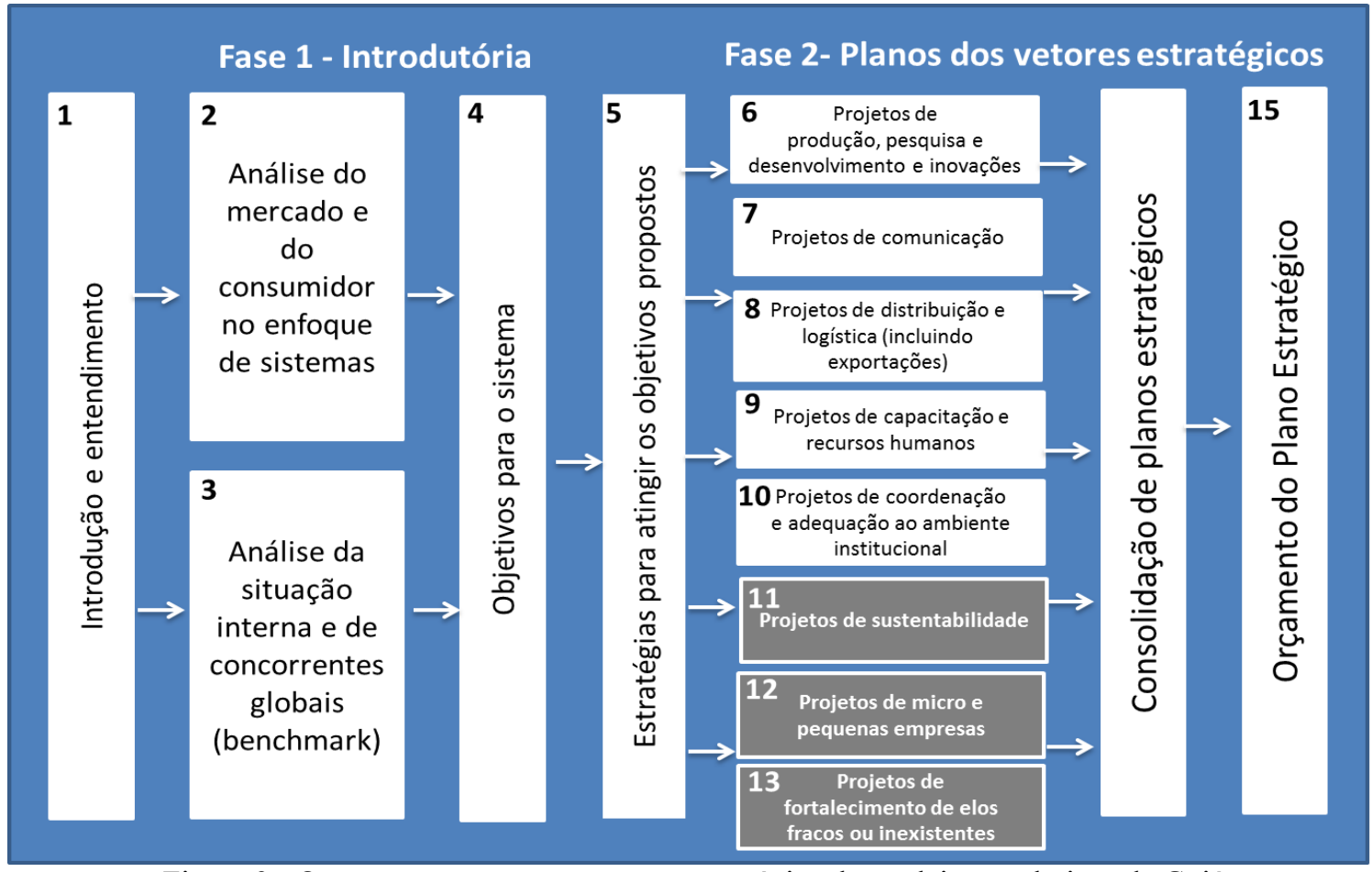

Figura 9 - Quatorze passos para a gestão estratégica das cadeias produtivas de Goiás. Fonte: Adaptado pela autora a partir de NEVES, 2008.

\subsection{1 - Os passos para a gestão estratégica}

\section{$\checkmark$ PASSO 1: INTRODUÇÃO E ENTENDIMENTO}

Esta fase é caracterizada pela reunião de todo material já existente relativo às cadeias alvo do estudo, bem como à sensibilização dos principais interlocutores de cada cadeia, a fim de aumentar e fortalecer o grupo de especialistas que ajudarão na reunião das informações e contribuirão nas fases seguintes do projeto. A fase de introdução e entendimento é fundamental para que o trabalho tenha um ponto de partida bem definido, com alguns direcionamentos já traçados. O método adaptado manteve as características já descritas no método GESis original.

\section{PASSO 2: ANÁlISE dO MERCADO E DO CONSUMIDOR NO ENFOQUE DE SISTEMAS}

Este passo envolveu um levantamento das principais informações referentes às cadeias produtivas estudadas. Ele contou com: análise de dados de produção, consumo, exportações e importações no Brasil e no mundo; caracterização do macro ambiente no qual as cadeias estão inseridas a fim de identificar as ameaças e oportunidades advindas 
de suas variáveis incontroláveis; análise do comportamento dos consumidores finais e intermediários no mercado interno e externo; e determinação dos polos que são referência das respectivas cadeias para a realização de benchmarking.

Para tanto, além de novos levantamentos de dados secundários, foram utilizadas duas ferramentas analíticas: a PEST e o modelo de Cinco Forças de Porter.

A PEST, ferramenta que analisa as ameaças e oportunidades advindas dos ambientes político-legal, econômico-natural, sociocultural e tecnológico em que o alvo de estudo está inserido, é uma importante ferramenta amplamente utilizada nos métodos de planejamento estratégico de organizações, e está presente no método GESis original (NEVES, 2005).

Já o modelo de Cinco Forças de Porter (PORTER, 1980), é muito utilizado para caracterizar e analisar as forças competitivas do microambiente de um setor ou indústria específica. O modelo aborda cinco dimensões e suas relações: a rivalidade entre concorrentes; a ameaça de novos entrantes; a ameaça de produtos substitutos; o poder de barganha dos fornecedores; e o poder de barganha dos clientes. Por meio deste modelo, é possível determinar a competitividade do mercado analisado. Cabe ressaltar que, recentemente, tal modelo vem sendo muito utilizado na análise de competitividade de Arranjos Produtivos Locais (APLs) (AFONSO, 2012).

O modelo das Cinco Forças de Porter foi incorporado ao método GESis original neste novo método, pois ele auxilia na identificação e análise das relações verticais das cadeias (entre diferentes elos), das relações horizontais (agente presentes no mesmo elo da cadeia) e até nos relacionamentos com outras cadeias, analisando os produtos substitutos e os concorrentes.

\section{PASSO 3: ANÁLISE DA SITUAÇÃO INTERNA E DE CONCORRENTES GLOBAIS}

Neste passo, foram levantados os pontos fortes e fracos de cada cadeia; mapeados os relacionamentos e formas de coordenação entre seus diferentes elos; analisados seus recursos e competências internas; identificados os fatores críticos de sucesso; e avaliados os polos de referência identificados anteriormente.

Para tanto, foram utilizadas duas ferramentas analíticas: a SWOT e o modelo do Diamante de Porter.

A SWOT é uma das ferramentas mais usadas para uma organização definir suas ações estratégicas. A ampla utilização desta ferramenta é justificada, pois ela proporciona uma 
análise interna da organização, por meio das suas forças e fraquezas, ao mesmo tempo em que determina como a organização está posicionada frente o seu ambiente externo, avaliando as ameaças e oportunidades (COMAN, RONEN, 2009).

Já o modelo do Diamante de Porter, incorporado ao método GESis original, busca fornecer as bases da competitividade de um setor em determinada localização geográfica. Para tanto, ele analisa quatro dimensões: estratégia, estrutura e rivalidade das empresas do setor; condições de demanda; indústrias correlatas e de apoio; e as condições de fatores de produção (PORTER, 1997).

Para realização desta etapa foram realizadas 35 entrevistas em profundidade, semiestruturadas com especialistas das cadeias alvo do trabalho. Foram entrevistados produtores rurais, gestores de empresas processadoras e de indústrias de transformação, pesquisadores e técnicos de órgãos ligados ao governo do estado. Mais detalhes a respeito das entrevistas serão dados na seção de metodologia. O roteiro das entrevistas está disponível no Apêndice B.

$\checkmark$ PASSOS 4 E $5:$ OBJETIVOS PARA AS CADEIAS PRODUTIVAS E ESTRATÉGIAS PARA ATINGIR OS OBJETIVOS PROPOSTOS

Para que ocorra a realização de qualquer planejamento estratégico, é necessário que sejam determinados objetivos e metas. Somente desta maneira podem ser traçadas as estratégias necessárias para alcançá-los (NEVES, 2005). Neves (2005) afirma que os objetivos podem ser quantitativos ou qualitativos, porém o problema que envolve a determinação de objetivos não mensuráveis é a dificuldade do acompanhamento dos resultados, que pode resultar em uma perda de interesse pelo plano.

O passo de definição dos objetivos estratégicos do método adaptado também contou com alterações frente ao método GESis original. Neste passo, foi estabelecido o ano de 2020 como a meta para realização dos projetos estratégicos e as seguintes atividades foram envolvidas (OTTO; NEVES; PINTO, 2012):

- definição do posicionamento estratégico para Goiás em 2020: mediante as expectativas dos stakeholders e a posição dos polos de referência para Goiás, é estruturada uma matriz, na qual se mostra o posicionamento atual do estado e de seus principais benchmarks e o seu posicionamento almejado para a data estabelecida. Vale lembrar que o objetivo é buscar um posicionamento que diferencie o estado de seus principais concorrentes.

- definição da missão e visão das cadeias: a missão traduz a razão de ser das cadeias, enquanto a visão explicita onde a cadeia quer chegar em 2020. 
- definição de objetivos estratégicos: os objetivos estratégicos também têm o foco no ano de 2020 e devem estar alinhados com o posicionamento estratégico, a missão e a visão pré-estabelecidos.

$\mathrm{Na}$ aplicação do método adaptado, tais definições foram sugeridas a partir das análises anteriores e foram então apresentadas em workshops com empresários da indústria processadora e de transformação, dirigentes de sindicatos patronais e de associações de produtores, técnicos da FAEG, do Sifaeg, da SGPA, da Seagro, do SEBRAE, da CIC, da Segplan, pesquisadores da Embrapa e professores e pesquisadores da UFG. Foram realizados cinco workshops, os quais foram divididos por cadeia produtiva (grãos, carne bovina, aves e suínos, lácteos e cana-de-açúcar). Inicialmente foram apresentadas as considerações prévias e cada ponto foi minuciosamente interpretado e discutido, para então se chegar a uma conclusão conjunta.

\section{$\checkmark$ PASSOS 6 A 13: PLANOS DOS VETORES ESTRATÉGICOS}

Os passos que seguem são referentes à estruturação dos projetos estratégicos para as cadeias produtivas estudadas. Os projetos foram desenvolvidos tendo como base todas as análises anteriores e a identificação dos principais problemas que cercam cada uma das cadeias estudadas. Após elaboração dos projetos estratégicos, estes foram levados a um workshop, onde os participantes (agentes ligados diretamente a cada cadeia) deram suas contribuições e validaram todos os projetos sugeridos.

Contando com outra adaptação ao método GESis original, o método adaptado aborda oito vetores, nos quais os projetos estratégicos foram divididos (o método original conta com apenas cinco vetores estratégicos). Para cada cadeia produtiva estudada (grãos, aves e suínos, carne bovina, lácteos e cana-de-açúcar) foram propostos projetos estratégicos nas seguintes áreas.

1. Produção, produto, pesquisa e desenvolvimento e inovação;

2. Comunicação;

3. Distribuição, logística e exportações;

4. Capacitação e recursos humanos;

5. Coordenação e adequação ao ambiente institucional;

6. Sustentabilidade;

7. Micro e pequenas empresas; 
8. Fortalecimento dos elos fracos ou faltantes.

Para cada projeto estratégico foram propostos um conjunto de ações fundamentais, visando ao alcance dos objetivos e ao desenvolvimento sustentável das cadeias produtivas.

PASSOS 14 E 15: CONSOLIDAÇÃO DE PROJETOS ESTRATÉGICOS E ORÇAMENTO DO PLANO ESTRATÉGICO

Os passos 14 e 15, apesar da necessidade de sua execução, não fazem parte do método adaptado. Eles deverão ser realizados pelos agentes da cadeia de acordo com suas prioridades, recursos, capacidades e competências.

O Quadro 4 a seguir, mostra as principais inserções realizadas no método GESis original, e seus objetivos. 
Quadro 4 - Principais diferenças entre o método GESis original e o método modificado.

* Os PASSOS são referentes aos 15 passos da etapa 4 do método.

\begin{tabular}{|c|c|c|}
\hline PASSO & $\begin{array}{l}\text { ALTERAÇÃO DO } \\
\text { MÉTODO GESis } \\
\text { ORIGINAL }\end{array}$ & OBJETIVO DA ALTERAÇÃO \\
\hline 2 & $\begin{array}{l}\text { Inclusão do modelo de } \\
\text { Cinco Forças de Porter }\end{array}$ & $\begin{array}{l}\text { Determinar a competitividade do setor } \\
\text { analisado por meio da determinação } \\
\text { das forças presentes nos } \\
\text { relacionamentos verticais, horizontais } \\
\text { e com cadeias concorrentes. }\end{array}$ \\
\hline 3 & $\begin{array}{l}\text { Inclusão do modelo do } \\
\text { Diamante de Porter }\end{array}$ & $\begin{array}{c}\text { Analisar as bases da competitividade } \\
\text { do setor na localização geográfica em } \\
\text { que se encontra. }\end{array}$ \\
\hline 4 & $\begin{array}{l}\text { Definição da missão e } \\
\text { visão da cadeia }\end{array}$ & $\begin{array}{l}\text { Balizar os objetivos estratégicos } \\
\text { definidos para cada cadeia por meio da } \\
\text { síntese do posicionamento estratégico. }\end{array}$ \\
\hline 5 & $\begin{array}{l}\text { Definição do } \\
\text { posicionamento } \\
\text { estratégico }\end{array}$ & $\begin{array}{l}\text { Deixar claro qual o posicionamento } \\
\text { estratégico almejado pelo estado que o } \\
\text { diferencie de seus principais } \\
\text { concorrentes. }\end{array}$ \\
\hline 11 & $\begin{array}{l}\text { Adição do vetor } \\
\text { "Sustentabilidade" }\end{array}$ & $\begin{array}{c}\text { Estabelecer ações relacionadas } \\
\text { diretamente à sustentabilidade, } \\
\text { enfatizando a importância desse tema } \\
\text { no atual contexto. }\end{array}$ \\
\hline 12 & $\begin{array}{l}\text { Adição do vetor } \\
\text { "Micro e pequenas } \\
\text { empresas" }\end{array}$ & $\begin{array}{l}\text { Desenvolver ações específicas para } \\
\text { que micro e pequenas empresas se } \\
\text { tornem mais competitivas no estado. }\end{array}$ \\
\hline 13 & $\begin{array}{l}\text { Adição do vetor } \\
\text { "Fortalecimento dos } \\
\text { elos fracos e } \\
\text { inexistentes" }\end{array}$ & $\begin{array}{l}\text { Fomentar o surgimento e } \\
\text { fortalecimento de negócios } \\
\text { relacionados às cadeias estudadas no } \\
\text { próprio estado, aumentando as } \\
\text { compras e negócios locais. }\end{array}$ \\
\hline
\end{tabular}

Fonte: Elaborado pelo autor.

Como o presente método objetiva a formulação do plano estratégico e o posterior monitoramento para futuras adequações, a execução do plano é responsabilidade da organização setorial com os agentes da cadeia sensibilizados. 


\section{MÉTODO}

A metodologia está apresentada em três etapas: caracterização do tipo de pesquisa, etapas de execução do trabalho e detalhamento dos estudos de caso alvo do trabalho.

Em sua obra, Gil (1999, p.42) afirma que a pesquisa social pode ser definida como “[...] o processo que, utilizando a metodologia científica, permite a obtenção de novos conhecimentos no campo da realidade social".

Daí decorre a importância de uma metodologia bem estruturada que é evidenciada por Cooper e Schindler (2003) quando afirmam que a qualidade da pesquisa depende do cumprimento dos padrões de um método científico. Os autores ainda destacam que "Uma boa pesquisa gera dados confiáveis, sendo derivada de práticas conduzidas profissionalmente e que podem ser usadas com segurança na tomada de decisão gerencial" (COOPER; SCHINDLER, 2003, p. 33).

\subsection{Tipo de pesquisa}

Para que uma pesquisa tenha a capacidade de solucionar um problema de marketing, inicialmente é preciso determinar a sua concepção, que seria o detalhamento dos procedimentos a serem executados para obtenção de todas as informações necessárias. Para Malhotra (2006), a pesquisa pode ser classificada em sua concepção como:

- Exploratória: é utilizada quando seu principal objetivo é a compreensão de uma situação-problema e normalmente é a primeira fase da estrutura geral de uma pesquisa (MALHOTRA, 2006).

- Descritiva: busca (1) descrever fenômenos ou características associadas à população-alvo, (2) estimar as proporções de uma população que tenha essas características (3) descobrir associações entre diferentes variáveis (COOPER; SCHINDLER, 2003).

- Causal: contém um caráter causal que busca estabelecer e mensurar as relações de causa e efeito entre as variáveis (COOPER; SCHINDLER, 2003).

Apesar de uma pesquisa não dever, necessariamente, fazer uso de apenas uma concepção (MALHOTRA, 2006), o presente trabalho contempla uma pesquisa de caráter 
exploratório; dessa maneira, a seguir será realizada uma descrição mais profunda do que é uma pesquisa exploratória.

A pesquisa exploratória justifica-se quando o pesquisador dispõe de poucas informações acerca do assunto e não pretende testar hipóteses específicas (HAIR; MONEY; SAMOUEL, 2005). Selltiz et al. (1967) complementam, afirmando que a pesquisa exploratória busca uma nova compreensão acerca de um fenômeno.

Para alguns pesquisadores (HAIR; MONEY; SAMOUEL, 2005; MALHOTRA, 2006), a pesquisa exploratória tem como principal objetivo aumentar a compreensão acerca do fenômeno estudado, promovendo a aproximação desse fenômeno com o tema na busca de uma nova interpretação dos fatos. Ela identifica necessidades de ações, bem como traz dados adicionais antes do desenvolvimento da abordagem. Também pode servir de subsídio para que outras pesquisas sejam capazes de formular um problema mais preciso ou criar novas hipóteses.

Malhotra (2006) considera ainda que em uma pesquisa exploratória a amostra é pequena e não significativa, seus dados primários são de natureza qualitativa e devem ser analisados como tal. Uma vez que a pesquisa exploratória considera muitos aspectos diferentes de um fenômeno, o seu planejamento deve ser flexível o suficiente, possibilitando a abordagem necessária durante sua execução.

Para Gil (1999), dentre os tipos de pesquisa abordados, a exploratória é aquela que apresenta menor rigidez no seu planejamento. Uma pesquisa exploratória pode atingir seus objetivos por meio de diferentes técnicas classificadas entre quantitativas e qualitativas. Usualmente, são utilizadas as técnicas qualitativas em uma exploração (COOPER; SCHINDLER, 2003; MALHOTRA, 2006).

A aplicação empírica de um método de gestão estratégica de sistemas agroindustriais em um recorte estadual caracteriza-se fortemente como uma pesquisa exploratória, uma vez que tem como objetivo explorar uma situação a fim de fornecer subsídios para a definição e compreensão de critérios facilitando a interpretação do fenômeno estudado e a criação de novas ideias e hipóteses. Para tanto, a pesquisa lançou mão de procedimentos qualitativos, quando se tratava da análise dos dados, que serão tratados no próximo item. 


\subsubsection{A Pesquisa Qualitativa}

Como introduzido na seção anterior, a pesquisa exploratória utiliza, na maioria das vezes, técnicas qualitativas para atingir seus objetivos.

Para Malhotra (2006, p.155), a pesquisa qualitativa é uma "metodologia de pesquisa não estruturada e exploratória baseada em pequenas amostras que proporciona percepções e compreensão do contexto do problema".

A relação entre a pesquisa qualitativa e a quantitativa pode ser interpretada e comparada da mesma maneira que se relacionam as pesquisas exploratória e conclusiva. Em uma pesquisa qualitativa, buscam-se melhores visão e compreensão do contexto do problema, enquanto que na pesquisa quantitativa os dados são quantificados $e$ analisados estatisticamente (MALHOTRA, 2006). Richardson (2008) complementa afirmando que o método qualitativo se diferencia do quantitativo basicamente por não utilizar ferramentas estatísticas como base do processo de análise do problema.

Segundo Neves (1996), os métodos qualitativos de pesquisa descrevem e decodificam sistemas com significados complexos a partir de um conjunto de diferentes técnicas interpretativas. O pesquisador exerce uma função central na definição dos resultados da pesquisa podendo até ser considerado como uma variável do projeto de pesquisa (APPELBAUM, 2003).

Os métodos de coleta utilizados para tal podem ser: entrevistas em profundidade, observação do participante, estudo de caso e análise de dados secundários, porém eles devem ser flexíveis e versáteis (COOPER; SCHINDLER, 2003; MALHOTRA, 2006; SELLTIZ, et al., 1967).

\subsubsection{O Estudo de Caso:}

O método do estudo de caso é uma importante ferramenta de pesquisa nas ciências sociais, não apenas como um método para gerar hipóteses em futuros estudos quantitativos, mas principalmente para gerar e testar uma teoria (APPELBAUM, 2003).

Bonoma (1985) afirma que um estudo de caso é guiado por um modelo que leva a (1) um conjunto de generalizações teóricas a partir das observações clínicas, (2) testes de 
restrições para esses conjuntos de generalizações e (3) uma teoria válida de algum fenômeno de marketing.

Para Yin (2001, p.19):

[...] os estudos de caso representam a estratégia preferida quando se colocam questões do tipo "como" e "por que", quando o pesquisador tem pouco controle sobre os eventos e quando o foco se encontra em fenômenos contemporâneos inseridos em algum contexto da vida real.

Yin (2001) considera também que processos organizacionais e administrativos são melhor abordados por meio de estudos de caso.

A construção de um estudo de caso implica múltiplas pesquisas, dependendo fortemente de relatos verbais (entrevistas) e de observações de dados primários. O estudo de caso diverge de outros estudos qualitativos, pois analisa muitas fontes de dados ao mesmo tempo, possibilitando a triangulação dos mesmos e proporcionando uma visão completa da unidade de estudo (BONOMA, 1985).

Ao final de todas as análises de dados (primários e secundários), a preocupação final do pesquisador é a provisão de sua visão e interpretação acerca do que foi estudado. Essa fase é altamente dependente da maneira como o pesquisador interpreta e dá significado aos achados da pesquisa (BONOMA, 1985).

Preconiza-se que os estudos de casos envolvam uma análise profunda de um número pequeno de situações (CAMPOMAR, 1991).

Os projetos de estudo de caso têm diversas variantes, entre elas estudos de caso únicos e estudos de casos múltiplos. Os estudos de caso múltiplos dão maior consistência e poder de convencimento ao estudo, tendo como resultado final um trabalho mais robusto do que aquele resultante da aplicação de um estudo de caso único (YIN, 2001).

Para Eisenhardt (1989), em um estudo multi-casos, devem ser avaliados de quatro a dez casos. Ele argumenta que com menos de quatro casos a teoria não será gerada de maneira satisfatória e com um número acima de dez casos a sistematização dos dados fíca comprometida, devido ao seu grande volume.

A Figura 10 ilustra um esquema proposto por Yin $(2010$, p. 82), no qual os procedimentos adotados em uma estratégia de pesquisa são relacionados à opção de um procedimento multi-casos. 


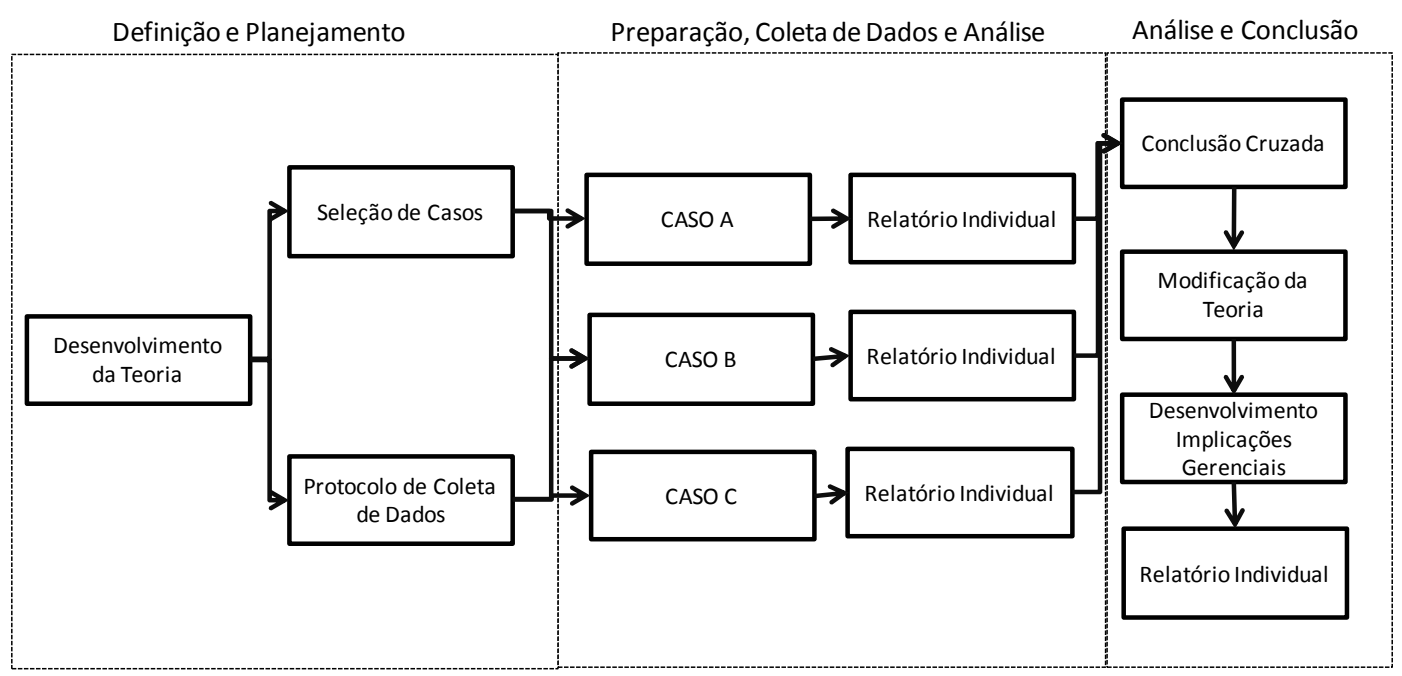

Figura 10 - Método Multi-casos

Fonte: Adaptado de Yin (2010).

De acordo com o esquema acima e com os passos propostos por Appelbaum (2003) para a execução de um estudo de caso, na fase inicial devem ser definidos os casos que serão estudados e realizada uma revisão de bibliografia para a construção de uma teoria inicial a respeito deles.

Appelbaum (2003) preconiza que o estudo de caso deve seguir a sequência de passos proposta a seguir: (1) determinar o objeto de estudo, (2) selecionar os casos, (3) construir uma teoria inicial a partir de uma revisão de literatura, (4) selecionar e organizar os métodos de coleta, (5) analisar os dados coletados e chegar a conclusões a partir desses dados.

Da mesma forma que Appelbaum (2003), Yin (2010) afirma que, para se realizar uma pesquisa envolvendo um estudo multi-casos, é fundamental a execução prévia de um protocolo que contenha os procedimentos e regras básicas a serem seguidos durante a pesquisa. Para tanto, o autor sugere uma sequência de quatro passos. A seguir são apresentados os quatro passos propostos por Yin (2010) com uma breve explicação de como cada um foi conduzido no presente trabalho. Mais detalhes acerca dos estudos de caso e de cada passo executado serão encontrados no capítulo seguinte.

\section{Estabelecimento da visão geral do projeto contendo detalhes como objetivos principais, formas de viabilização do projeto e pré-leituras essenciais.}

Os estudos de caso do presente trabalho foram conduzidos no estado de Goiás com cinco cadeias produtivas estaduais, que contaram com a aplicação de um método de gestão estratégica.

Frente às divergências e especificidades dos diferentes métodos de planejamento e gestão estratégica existentes na literatura e as diferentes características encontradas em 
cada cadeia produtiva, o principal objetivo dos estudos de caso foi a avaliação de cada etapa do método para, posteriormente, inserir novas ferramentas ou fazer alterações que sejam aplicáveis em cadeias produtivas delimitadas a um recorte estadual.

A execução dos estudos de caso foi viabilizada devido a uma demanda da Federação das Indústrias do Estado de Goiás (FIEG) de mapear e organizar suas cadeias produtivas, buscando também o levantamento e divulgação de dados específicos e fundamentais de cada cadeia.

\section{Descrição dos procedimentos a serem realizados incluindo detalhes} como fontes de informações, acesso a pessoas e locais estratégicos, entre outros.

Quanto aos procedimentos utilizados para levantamento de informações, os estudos de caso contaram com pesquisas de dados secundários, entrevistas semiestruturadas e workshops.

A elaboração do plano estratégico foi realizada a partir dos dados coletados e, posteriormente, o plano foi validado em workshops e entrevistas.

$\mathrm{O}$ acesso aos entrevistados e a realização dos workshops foram facilitados pela FIEG.

3. Detalhamento das questões principais que o estudo de caso busca responder.

As principais questões que os estudos de caso buscaram responder foram:

- Quais as dificuldades encontradas na aplicação de um método de gestão estratégica em cadeias produtivas em um recorte estadual?

- Quais ferramentas são adequadas e quais não são para tal?

- Qual a melhor forma de ordenar a aplicação dessas ferramentas em um método específico para cadeias produtivas delimitadas a um recorte estadual?

4. Formato do relatório do estudo de caso, ou seja, como serão apresentados os resultados.

Uma vez que os resultados contaram com muitos detalhes específicos de cada cadeia, estes não são apresentados na íntegra, visto que o objetivo do presente trabalho não é divulgar dados específicos das cadeias, mas sim avaliar o método utilizado.

A apresentação dos resultados limita-se a uma caracterização de cada cadeia produtiva (situação da cadeia no cenário mundial, nacional e estadual), a apresentação dos principais problemas encontrados em cada cadeia, a determinação do posicionamento estratégico de cada cadeia e a proposição final de objetivos e projetos estratégicos para cada uma. 
Segundo Mattar (1993), os dados coletados podem ser de duas origens diferentes: dados primários e dados secundários.

Os dados primários são aqueles que nunca foram coletados anteriormente, cabendo ao pesquisador desenvolver meios de coletá-los de forma a atender as necessidades da pesquisa a que se propõe. Já os dados secundários são aqueles que já foram coletados e tabulados anteriormente à pesquisa, porém, para outros fins, e estão à disposição para consultas de terceiros.

Gil (2006) define os dados primários como "aqueles cujos dados são fornecidos por pessoas", já os secundários são definidos como "aqueles que se valem das chamadas 'fontes de papel'", sendo classificados em pesquisa bibliográfica e pesquisa documental (GIL, 2006, p.43).

Apesar de os dados primários serem coletados com o objetivo específico de abordar o objeto de estudo, os dados secundários apresentam algumas vantagens, entre elas estão que os mesmos são de fácil acesso e de obtenção mais rápida que os dados primários (MALHOTRA, 2006).

Após coletados, os dados devem ser analisados a fim de se chegar a conclusões que contribuam com a teoria inicial.

O presente trabalho é uma pesquisa exploratória, que usou estratégias qualitativas para a sua execução. Foram realizadas uma revisão bibliográfica profunda e a investigação de múltiplos casos objetivando, pela formulação de um problema, uma investigação detalhada acerca do objeto de estudo.

\subsection{Etapas da pesquisa}

Para facilitar o entendimento, será apresentado, a seguir, um esquema do plano de trabalho e dos procedimentos adotados na pesquisa:

(1) Pesquisa e entendimento acerca de planejamento e gestão estratégica (revisão de literatura)

Nesta primeira etapa foi revisada a literatura a respeito dos Sistemas Agroindustriais, de Planejamento Estratégico e de Gestão Estratégica. 
(2) Apresentação do modelo GESis e do modelo adaptado para aplicação no estado de Goiás

Foi feita uma análise do modelo GESis de Planejamento e Gestão Estratégica de cadeias produtivas proposto por Neves (2008) e sua adaptação para aplicação nos estudos de caso do presente trabalho.

(3) Análise de estudos de caso de gestão estratégica para sistemas agroindustriais em Goiás.

Nesta etapa foram aplicados e analisados os estudos de caso alvo do presente trabalho. Nos casos estudados, foram realizados procedimentos de gestão estratégica de cadeias produtivas delimitadas ao estado de Goiás. O estudo de caso contou com pesquisa de dados secundários, entrevistas em profundidade, workshops e com a sugestão de projetos estratégicos a serem adotados pelo estado.

(4) Realização de entrevistas semiestruturadas com os principais responsáveis pela implementação e execução dos projetos estratégicos emergentes do plano estratégico para o estado.

Uma vez que o método aplicado nos casos alvo deste estudo teve como principal resultado a proposição de projetos e ações estratégicas, nesta etapa do trabalho foram conduzidas entrevistas semiestruturadas com os principais responsáveis pela implementação e execução dos projetos, com o objetivo de identificar possíveis problemas e sugestões para o Método de Gestão Estratégica de Cadeias Produtivas para um Recorte Estadual.

Nesta etapa foram realizadas duas entrevistas, sendo uma com o coordenador geral do projeto na FIEG e presidente da Câmara Setorial de Agronegócio na ocasião e outra com a Assessora Técnica da FIEG/COTEC.

(5) Finalização do Método de Gestão Estratégica de Cadeias Produtivas para um Recorte Estadual:

A partir da análise dos métodos de planejamento existentes, da aplicação do método de planejamento estratégico no estado de Goiás resultando nos estudos de caso e das entrevistas semiestruturadas realizadas com os principais responsáveis pela implementação e execução, foi finalizado o Método de Gestão Estratégica de Cadeias Produtivas para um Recorte Estadual.

A Figura 11 explicita a sequência de etapas desenvolvidas no presente trabalho e os objetivos que cada etapa da pesquisa buscou atingir. 




Figura 11 - Etapas e objetivos metodológicos.

Fonte: Elaborado pelo autor.

\subsection{Os estudos de caso}

Os estudos de caso contemplam a aplicação empírica do método GESis adaptado em cinco cadeias produtivas do estado de Goiás. Segundo Neves (2008), o método GESis original pode ser adaptado a cada nova aplicação com a contribuição de novas teorias que surgem ao redor do mundo e com novas análises criativas que emergem de cada SAG estudado em particular. A escolha do método GESis para tal foi feita por ele contemplar a maioria das fases encontradas nos métodos de planejamento e gestão estratégica revisados e já possuir um viés específico para cadeias produtivas, algo que os outros métodos revisados não possuem.

As cinco cadeias produtivas estudadas foram:

- Grãos - milho e soja;

- Aves e suínos;

- Carne bovina;

- Lácteos;

- Sucroenergética.

A iniciativa da aplicação de um método de gestão estratégica em cadeias produtivas do estado de Goiás partiu da Federação das Indústrias do Estado de Goiás (FIEG) na busca de mapear a situação atual e o futuro desejado do agronegócio goiano. Por meio da aplicação, a FIEG buscou suprir a carência de informações e estudos que possam servir de base para a 
estruturação de políticas públicas e estratégias empresariais, tendo como principal objetivo propiciar o desenvolvimento e maior competitividade dos diversos setores da economia do estado.

Para viabilizar a aplicação do método GESis nas cadeias produtivas do estado de Goiás, foram realizadas diversas parcerias com os seguintes órgãos: Sebrae, Seagro, SIC, UFG, Segplan, Semarh, Alfa, Sectec, Faeg, Fecomércio, Seinfra, PUC - GO, Assembléia Legislativa, Embrapa, Sifaeg, Sindileite, Sindicarne e Sindicurtume, facilitadas pela FIEG.

As primeiras reuniões aconteceram em junho de 2011, sendo que posteriormente aconteceram mais sete encontros, divididos entre reuniões e workshops.

A autora participou ativamente da aplicação do método nas cadeias descritas acima, tendo papel ativo em entrevistas e workshops relacionados com a validação dos dados, bem como na finalização da proposta do plano estratégico. Outros planejadores também auxiliaram em algumas fases do projeto, porém a autora acompanhou diretamente toda a evolução do projeto.

A sequência prática de atividades realizadas na aplicação do método GESis adaptado nas cinco cadeias produtivas do estado de Goiás está esquematizada na

Figura 12 e descritas em seguida.

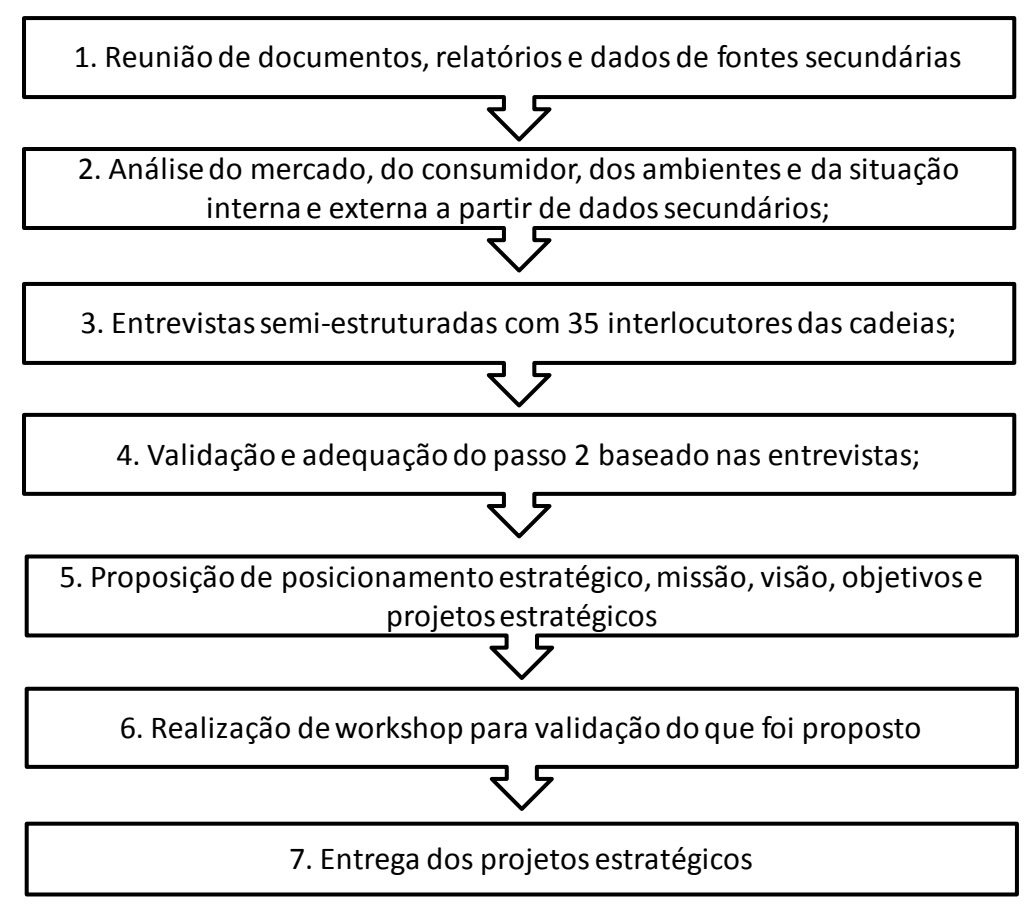

Figura 12 - Sequência de ações executadas para a aplicação do método GESis adaptado no estado de Goiás. Fonte: Elaborado pelo autor. 


\section{Reunião de documentos, relatórios e dados de fontes secundárias}

Para iniciar a execução dos estudos de caso, foram reunidos documentos, relatórios e outros dados já existentes a respeito das cadeias em Goiás. Foram documentos necessários para iniciar a estruturação dos casos.

2. Análise do mercado, do consumidor, dos ambientes e da situação interna e externa a partir de dados secundários

Após reunião inicial de documentos, outras fontes de dados secundários foram consultadas visando complementar e estruturar ainda mais o arcabouço inicial de informações. Esses levantamentos contaram com dados de produção, consumo, mercados consumidores, evolução dos setores, dentre outros.

\section{Entrevistas semiestruturadas com 35 interlocutores das cadeias}

Após reunir documentos e proceder com uma análise de dados secundários, foram realizadas 35 entrevistas semiestruturadas com interlocutores das cinco cadeias.

A seleção dos entrevistados foi realizada juntamente com a FIEG, que indicou uma lista de 76 contatos para tentativa de entrevista. A lista inicial de contatos estava dividida como mostra o Quadro 5.

Quadro 5 - Número inicial de contatos fornecidos pela FIEG

\begin{tabular}{l|c}
\hline \multicolumn{1}{c|}{ Cadeia } & Número Inicial de Contatos \\
\hline Carne Bovina & 15 \\
Carne Suína e de Aves & 13 \\
Lácteos & 10 \\
Grãos - Milho e Soja & 14 \\
Setor Sucroenergético & 9 \\
Cadeias Diversas & 15 \\
\hline \multicolumn{1}{c|}{ TOTAL } & $\mathbf{7 6}$ \\
\hline
\end{tabular}

Fonte: Elaborado pelo autor.

Os contatos com os entrevistados e as entrevistas realizadas com aqueles dispostos a participar foram conduzidos por telefone. O Quadro 6 mostra o número de entrevistas realizadas para cada cadeia e os elos da cadeia representados nessas entrevistas (seus nomes e algumas organizações a que pertencem não puderam ser divulgados devido ao pedido de confidencialidade). 
Quadro 6 - Número e origem dos 35 entrevistados nos estudos de caso em Goiás.

\begin{tabular}{c|c|c}
\hline Cadeia & Entrevistas Realizadas & $\begin{array}{c}\text { Organizações } \\
\text { Participantes }\end{array}$ \\
\hline Carne Bovina & $\mathbf{6}$ & $\begin{array}{c}\text { EMBRAPA, UFG, SEAGRO, } \\
\text { SINDICARNES, Produtores } \\
\text { Rurais, Frigorírifoo }\end{array}$ \\
\hline Carne Suína e de Aves & $\mathbf{8}$ & $\begin{array}{c}\text { ADIAL, UFG, EMBRAPA, } \\
\text { FAEG, SIAEG, empresa de } \\
\text { processamento e distribuição, } \\
\text { SIC }\end{array}$ \\
\hline Lácteos & $\mathbf{6}$ & $\begin{array}{c}\text { EMBRAPA, SINDILEITE, } \\
\text { SEINFRA, FAEG, UFG, PUC } \\
\text { - GO }\end{array}$ \\
\hline Grãos - Milho e Soja & $\mathbf{9}$ & $\begin{array}{c}\text { Índústrias de Processamento, } \\
\text { SINTRIGO, Produtores } \\
\text { Rurais, EMBRAPA, } \\
\text { Consultoria de Exportaços, } \\
\text { UFG. }\end{array}$ \\
\hline Setor Sucroenergético & & $\begin{array}{c}\text { UFG, Secretaria do Estado, } \\
\text { Usinas Processadoras, } \\
\text { SEAGRO, SEMARH }\end{array}$ \\
\hline
\end{tabular}

Fonte: Elaborado pelo autor.

O roteiro das entrevistas semiestruturadas utilizado na execução dos estudos de caso pode ser encontrado no Apêndice $B$, sendo que o tempo médio de entrevista foi de 50 minutos (levando em consideração que alguns entrevistados se restringiam a responder apenas algumas partes do questionário). Por serem realizadas entrevistas com diversos agentes de diversas cadeias, não houve a execução de um pré-teste, sendo que o questionário era adaptado durante a entrevista, de acordo com as competências do entrevistado para resposta.

\section{Validação e adequação do passo 2, com base nas entrevistas}

Após entrevistas, foi feita uma revisão dos dados levantados na etapa 2 (Análise do mercado, do consumidor, dos ambientes e da situação interna e externa a partir de dados secundários), checando as consistências e inconsistências de ambas etapas e buscando unir e dar coerência às informações obtidas.

\section{Proposição de posicionamento estratégico, missão, visão, objetivos e} projetos estratégicos

Com base nos dados secundários levantados e nas entrevistas realizadas, foram propostos posicionamento estratégico, missão, visão, objetivos e projetos estratégicos para cada uma das cinco cadeias. 


\section{Realização de workshop para validação do que foi proposto}

Foram organizados pela FIEG cinco workshops (um por cadeia) para apresentação e validação das fases anteriores. Os workshops foram realizados na cidade de Goiânia e contaram com a participação de 30 interlocutores das cadeias, que foram selecionados e convidados pela FIEG. Alguns interlocutores participaram de mais de um workshop, contribuindo para mais de uma cadeia produtiva e alguns workshops contaram com mais de um interlocutor da mesma organização. O Quadro 7 mostra o número de interlocutores presentes no workshop dividido por cadeia.

Quadro 7 - Número e origem dos interlocutores presentes no workshop.

\begin{tabular}{c|c|c}
\hline Cadeia & Número de Presentes & Organizações Presentes \\
\hline Bovinos & 7 & $\begin{array}{c}\text { SEAGRO, SEBRAE, } \\
\text { SEGPLAN, Sociedade Goiana } \\
\text { de Pecuária e Agricultura } \\
\text { (SGPA), }\end{array}$ \\
CTCOMEX/COMING
\end{tabular}

Fonte: Elaborado pelo autor.

\section{Entrega dos projetos estratégicos}

Após a realização dos workshops, nos quais foram apresentados posicionamento estratégico, missão, visão, objetivos e projetos estratégicos para cada uma das cinco cadeias e sugestões de melhoria que foram dadas pelos participantes, os projetos estratégicos foram finalizados e entregues à FIEG como resultado final de seu projeto de gestão estratégica para cinco cadeias produtivas, finalizando-se, então, os casos alvo do presente estudo. 


\section{APRESENTAÇÃO E ANÁLISE DOS CASOS}

Esta etapa do trabalho apresentará os estudos de caso resultados da aplicação do método GESis nas cinco cadeias propostas para o estado de Goiás. Para cada SAG estudado será apresentada uma caracterização do setor no contexto mundial e o papel do Brasil neste contexto, a situação atual do SAG no estado de Goiás, os principais problemas encontrados nas análises executadas e os projetos estratégicos propostos na busca de solucionar estes problemas e impulsionar a cadeia para o posicionamento almejado.

\subsection{Carne bovina}

\subsubsection{Introdução à cadeia}

A carne bovina é uma das principais fontes proteicas consumidas no mundo. Ela contém aminoácidos essenciais de forma balanceada e uma quantidade de proteínas completas associadas a um baixo teor calórico. O grande crescimento populacional vivenciado na atualidade e a melhoria da distribuição de renda observada em alguns países são acompanhados do aumento da demanda por alimentos, principalmente aqueles com alto valor biológico como a carne bovina (NEVES et al., 2012).

Alguns atributos da carne bovina devem ser considerados quando o assunto é qualidade de carne, que vão desde aspectos intrínsecos como maciez, sabor, cor, textura, composição química, quantidade de gordura, entre outros, até aqueles observados nas suas formas de produção, processamento e comercialização (LUCHIARI FILHO, 2006).

A qualidade da carne está diretamente relacionada ao seu grau de padronização dos mais variados aspectos. Quanto mais padronizado o produto final, que depende de esforços de toda a cadeia para tal, maior o grau de qualidade que aquele produto oferece, pois ele passa a ser capaz de atender aos seus segmentos de mercado com maior assertividade.

Nos últimos 20 anos, a produção mundial de carne bovina apresentou crescimento acumulado de 23\%. Em 2002, os principais produtores mundiais eram, nesta sequência, Estados Unidos, União Europeia e Brasil. Já no ano de 2011, o Brasil superou a União 
Europeia, ocupando o segundo lugar no ranking dos maiores produtores mundiais do produto (UNITED STATES, 2013)

Com relação ao consumo mundial de carne bovina, o crescimento acumulado nos últimos 20 anos foi semelhante à produção, sendo em torno de $23 \%$, porém em meados de 2008 foi iniciada uma leve queda da demanda pelo produto. O principal fator que impulsionou essa queda foi a substituição do consumo deste tipo de proteína por outras de menores custos e benefícios semelhantes, como a carne de frango e a suína. Do ano de 2008 até o ano de 2011, o consumo mundial de carne bovina apresentou uma diminuição de cerca de $3 \%$ (UNITED STATES, 2013).

As oscilações nos números descritos acima justificam-se pela mudança do perfil dos consumidores que está ocorrendo atualmente. Países que possuem economias maduras e população diminuindo e envelhecendo passam a consumir menores quantidades de carne bovina, dando preferência para outras fontes proteicas, como é o caso dos países pertencentes à União Europeia, que em dez anos reduziram seu consumo de carne bovina em 9,3\%, enquanto o consumo de carne de frango aumentou 20\% (UNITED STATES, 2013).

Já naqueles países em pleno desenvolvimento, com sua população em crescimento exponencial e com forte redistribuição de renda, observa-se um aumento pela demanda deste tipo de produto. A Índia é um clássico exemplo dessa categoria de países, onde o consumo de carne bovina aumentou cerca de 37\% nos últimos dez anos (UNITED STATES, 2013).

Segundo dados da OCDE (2012), o consumo mundial de carne bovina crescerá 16\% até 2021 e sua produção deve seguir a mesma tendência para suprir a demanda.

A partir da análise das exportações, nota-se que a cada ano que passa maior é a integração da economia mundial, sendo que cada país passa a produzir e fornecer para o mundo o produto que seus fatores de produção são mais favoráveis a produzir. Com relação à carne bovina, os principais países exportadores no ano de 2010 foram Brasil (20\%), Austrália (18\%) e EUA (13\%) (UNITED STATES, 2013).

Neste cenário, apresentando o maior rebanho comercial do mundo, o Brasil aparece como segundo maior produtor de carne bovina, com pouco mais de nove milhões de toneladas de equivalente de carcaça produzidas em 2011, o que representa um crescimento de aproximadamente 30\% nos últimos 10 anos (UNITED STATES, 2013). Projeções indicam que até o ano 2022 sua produção aumentará mais 30\% (BRASIL, 2012a).

As exportações brasileiras de carne bovina aumentaram drasticamente nos últimos anos, contabilizando um aumento de 60\% nos últimos dez anos. Previsões indicam que até o ano de 2022 ela sofrerá um incremento de mais $20 \%$ (BRASIL, 2012a). 
Os números mostram que o cenário mundial no setor de carne bovina é muito favorável. A demanda é crescente e o Brasil possui disponibilidade dos principais fatores de produção. É fundamental a realização de um planejamento e a determinação dos direcionamentos a serem tomados para que o País cumpra seu papel e aproveite a oportunidade eminente da melhor maneira possível.

\subsubsection{Importância do setor para Goiás}

O estado de Goiás possui um rebanho de cerca de 22 milhões de cabeças (BRASIL, 2013c), quantidade que representa quase $10 \%$ de todo o rebanho nacional. Mesmo estando atrás de outros dois estados no efetivo de cabeças, no terceiro trimestre de 2013 o estado figurou como o mais produtivo do País (BRASIL, 2013b). A Tabela 1 mostra a comparação de produtividade dos principais estados produtores do País.

Tabela 1 - Comparação de rebanho, produção e produtividade dos principais estados produtores de carne bovina do Brasil.

\begin{tabular}{l|c|l|l|l|l|l}
\hline Estado & $\begin{array}{c}\text { Área de } \\
\text { Pastagem } \\
(2006)\end{array}$ & $\begin{array}{c}\text { Rebanho } \\
\text { (cabeças) }\end{array}$ & Cabeças/ha & $\begin{array}{c}\text { Animais } \\
\text { Abatidos } \\
\text { (julho- } \\
\text { setembro } \\
\text { 2013) }\end{array}$ & $\begin{array}{c}\text { Peso Total das } \\
\text { Carcaças (Kg) } \\
\text { (julho- } \\
\text { setembro 2013) }\end{array}$ & $\begin{array}{c}\text { Peso/Carcaça } \\
\text { (Kg) }\end{array}$ \\
\hline MT & 22.062 .659 & 28.740 .802 & 1,30 & 1.584 .067 & 399.937 .020 & 214,60 \\
MG & 18.217 .880 & 23.965 .914 & 1,31 & 792.842 & 186.991 .418 & 235,85 \\
GO & 15.838 .320 & 22.045 .776 & 1,40 & 927.069 & 230.643 .370 & 248,79 \\
MS & 21.055 .122 & 21.498 .382 & 1,02 & 1.009 .406 & 247.250 .265 & 244,95 \\
\hline
\end{tabular}

Fonte: Elaborado pelo autor a partir de BRASIL, 2013b; BRASIL, 2013c

Uma característica favorável ao estado é o seu grande número de confinamentos. Do ano de 2004 até o ano de 2012, o número de confinamentos do estado cresceu cerca de $80 \%$ (INFORMA ECONOMICS, 2012) impulsionado pela disponibilidade de grãos na região centro-oeste $-39 \%$ da produção nacional de milho e soja (INFORMA ECONOMICS, 2013).

Atualmente o estado é o que mais confina, respondendo por cerca de $35 \%$ de todo o gado confinado no País. O confinamento de animais é uma importante ferramenta para o controle da oferta de boi gordo, consequentemente a prática confere a Goiás maior controle sobre seus abates (ASSOCON, 2012). 
Quanto às exportações, o estado de Goiás figurou em terceiro colocado no ano de 2011, exportando cerca de 115 mil toneladas de carne bovina (BRASIL, 2013a). Para o estado, o complexo carnes é o segundo item mais exportado, representando, aproximadamente, $19 \%$ do seu total de exportações. Dentro do complexo carnes, a carne bovina se destaca, sendo responsável por cerca de 10\% do total das exportações do estado (SEGPLAN, 2012).

Quanto aos destinos das exportações, no ano de 2011 o estado exportou cerca de $50 \%$ da sua produção para apenas dois países (Rússia e Irã), o que mostra a alta dependência do estado por poucos países, indicando a necessidade de diversificação de mercados (BRASIL, 2013a).

Com relação às propriedades rurais do estado destinadas à pecuária, no ano do último censo (2006), o estado possuía 111.693 estabelecimentos criadores de bovinos, com número médio de cabeças de 163 por estabelecimento, o que resulta em um número total de cabeças de 18.234.548 cabeças no ano analisado (BRASIL, 2007).

Com relação a seu parque industrial, o estado de Goiás é o $4^{\circ}$ estado brasileiro com a maior capacidade de abate diária em seus frigoríficos (NEVES, 2012).

Segundo Neves, 2012, no ano de 2010, o estado possuía uma capacidade diária de abate de 20.354 cabeças, ficando atrás de estados como Mato Grosso, São Paulo e Mato Grosso do Sul. Considerando que no mesmo ano o estado abateu 1.966.095 cabeças (BRASIL, 2011), o que representa em torno de 7.800 cabeças por dia (considerando que o ano de 2010 teve 251 dias úteis) constata-se que a utilização de seu parque industrial foi de $38 \%$. Nesse aspecto, a oportunidade de aumentar a eficiência no campo e consequentemente utilizar maior fatia da capacidade de processamento industrial do estado é grande.

Para toda essa produção, o estado necessita de diversos tipos de insumos, seja para o campo ou para abastecer suas indústrias.

Com relação aos insumos utilizados no campo, como suplementos, grãos, defensivos, fertilizantes, arames e mourões, tratores e implementos, entre outros, estima-se que Goiás produza por volta de $90 \%$ do que necessita, sendo os outros $10 \%$ relativos a locais que possuem matérias-primas específicas, como jazidas de alguns minerais, por exemplo (OTTO; NEVES; PINTO, 2012).

Já para a indústria, a situação não é a mesma. Grande parte dos insumos utilizados tanto nos curtumes quanto nos frigoríficos (materiais de limpeza, embalagens, depilantes, conservantes, curtentes etc) não são produzidos em Goiás. Normalmente, os grandes grupos frigoríficos possuem centrais de compras que distribuem para todas as suas unidades nos mais 
variados estados. A atração de indústrias de insumos industriais para o estado e Goiás poderia reduzir o custo da produção do setor, além de trazer outros benefícios como a geração de empregos por exemplo (OTTO; NEVES; PINTO, 2012).

\subsubsection{Análise dos principais problemas}

A análise dos principais problemas enfrentados pela cadeia produtiva no estado de Goiás é resultado da consolidação de diversas ferramentas utilizadas no método aplicado e do resultado das entrevistas com especialistas.

O Quadro 8 apresenta a consolidação dos principais problemas enfrentados pela cadeia de carne bovina goiana.

Quadro 8 - Principais problemas encontrados na cadeia de carne bovina do estado de Goiás.

- Produção difusa com ausência de integração vertical.

- Baixo nível de organização setorial.

- Problemas de logística afetando o custo de produção.

- Alto grau de informalidade na cadeia.

- Área de marketing do setor muito pouco desenvolvida, deixando-o vulnerável a acusações diversas.

- Excesso de burocracia para acesso a financiamentos.

- Concentração da indústria, deixando os produtores com baixo poder de barganha.

- Elevada capacidade ociosa do parque industrial.

- Problemas ambientais relativos a pastagens degradadas.

- Necessidade de melhoria nos padrões sanitários do estado para acessar mercados mais exigentes e que remuneram melhor o produto.

Fonte: Elaborado pelo autor.

A partir da identificação desses problemas, foi traçado o posicionamento estratégico para o setor no estado e ele resume onde o estado pretende estar no ano de 2020. São duas dimensões principais que guiam esse posicionamento, sendo que a primeira diz respeito à coordenação vertical e a segunda trata de produtividade e qualidade do produto.

Para atingir o posicionamento almejado, o estado de Goiás deve investir esforços no fortalecimento de um sistema de coordenação vertical que auxilie a cadeia na sua organização, minimizando os conflitos e guiando as ações com um objetivo comum a todos os elos. 
Por outro lado, para ser altamente competitivo no mercado, o estado deve aumentar seus níveis de produtividade que atualmente estão em cerca de 1,4 cabeças/ha, sendo capaz de elevar sua produção sem utilizar novas terras. No aumento da produtividade, a qualidade do produto não pode ser esquecida, pois o estado espera atingir um nível de excelência no ano de 2020.

\subsubsection{Missão, visão, objetivos e ações estratégicas para o setor no estado}

\subsubsection{Missão e visão da cadeia}

\section{Missão}

Produzir carne e outros subprodutos bovinos com qualidade, de maneira a atender de forma ambiental e economicamente sustentável às necessidades da população, por meio de avanços tecnológicos e do trabalho conjunto entre os elos da cadeia.

\section{Visão}

Ser o estado referência na produção de carne bovina atingindo altos níveis de produtividade e qualidade, por meio de coordenação e uso de novas tecnologias.

\subsubsection{Objetivos e ações estratégicas}

Como descrito na metodologia do trabalho, os projetos estratégicos foram definidos a partir da união das análises realizadas e dos objetivos e metas traçados para cada cadeia produtiva e foram validados em workshop com especialistas do setor no estado. Para melhor organização e mais fácil execução dos planos estratégicos, eles foram divididos em oito, cada um representando uma dimensão que deve ser trabalhada no estado. Nesta seção serão descritos os objetivos, e as principais ações traçadas em cada projeto estratégico. 
Quadro 9 - Planos vetores estratégicos, objetivos e ações estratégicas propostas para a cadeia de carne bovina do estado de Goiás

\begin{tabular}{|c|c|c|}
\hline Planos Vetores Estratégicos & Objetivos & Ações Estratégicas \\
\hline $\begin{array}{l}\text { 1. Produção, produtos, } \\
\text { pesquisa e inovação }\end{array}$ & $\begin{array}{l}\text { - Aumentar a produção de carne bovina no estado de } \\
\text { - Moiás. } \\
\text { Melhorar a qualidade da carne de forma a atender os } \\
\text { mercados mais exigentes. } \\
\text { - Incentivar pesquisas voltadas à cadeia. }\end{array}$ & $\begin{array}{l}\text { - Incentivar a prática de confinamentos. } \\
\text { - Destinar crédito de fácil acesso para reestruturação de unidades industriais. } \\
\text { - Buscar maiores volumes de verbas para pesquisa, desenvolvimento e } \\
\text { inovação. }\end{array}$ \\
\hline 2. Comunicação & $\begin{array}{l}\text { - Aumentar o consumo interno e externo de carne } \\
\text { bovina; } \\
\text { - Melhorar a comunicação e a troca de conhecimentos } \\
\text { inter e entre elos da cadeia }\end{array}$ & $\begin{array}{l}\text { - Utilizar a denominação de origem nos mercados externos. } \\
\text { - Trabalhar pró-ativamente na área de marketing. } \\
\text { - Elaborar materiais de casos de sucesso para distribuição interna na cadeia. } \\
\text { - Incentivar produtores a compartilharem experiências em bancos de dados } \\
\text { disponíveis. }\end{array}$ \\
\hline $\begin{array}{l}\text { 3. Distribuição, logística e } \\
\text { exportações }\end{array}$ & $\begin{array}{l}\text { - } \quad \text { Reduzir custos logísticos para a cadeia. } \\
\text { - } \quad \text { Reduzir a dependência do modal rodoviário. } \\
\text { de Goiás. }\end{array}$ & $\begin{array}{l}\text { - Melhorar condições de estradas e vicinais e fazer manutenção } \\
\text { frequentemente. } \\
\text { - Buscar formas de redução no custo portuário. } \\
\text { - Buscar, no governo federal, possibilidades de novas parcerias para } \\
\text { exportação. }\end{array}$ \\
\hline $\begin{array}{l}\text { 4. Capacitação/Recursos } \\
\text { Humanos }\end{array}$ & $\begin{array}{l}\text { - Capacitar e qualificar os recursos humanos dos } \\
\text { diversos elos da cadeia. } \\
\text { - } \quad \text { Adequar todos à legislação trabalhista. } \\
\text { - } \quad \text { Reduzir a rotatividade de trabalhadores }\end{array}$ & $\begin{array}{l}\text { Incentivar e divulgar cursos oferecidos pelo Sistema } \mathrm{S} \text { e criar novos cursos } \\
\text { de acordo com a necessidade. } \\
\text { - } \quad \text { Fomentar iniciativas privadas para realização de treinamentos técnicos. } \\
\text { - Legalizar toda mão-de-obra presente na cadeia. }\end{array}$ \\
\hline $\begin{array}{l}\text { 5. Coordenação e adequação } \\
\text { ao ambiente institucional }\end{array}$ & $\begin{array}{l}\text { Elevar o nível de coordenação e integração da } \\
\text { cadeia. } \\
\text { - } \quad \text { Verticalizar a cadeia por meio de } \\
\text { - } \quad \text { Auxiliar participantes com a questão dos tributos. }\end{array}$ & $\begin{array}{l}\text { - Identificar pessoal adequado para ocupar posições de articuladores na } \\
\text { organização vertical. } \\
\text { - Avaliar a situação de cooperativas já existentes, analisando oportunidades. } \\
\text { - Incentivar elos da cadeia a reverter impostos (IR) em programas sociais e } \\
\text { ambientais. }\end{array}$ \\
\hline 6. Sustentabilidade & $\begin{array}{l}\text { - } \quad \text { Desenvolver tecnologias voltadas à sustentabilidade. } \\
\text { - } \quad \text { Estimular a certificação de propriedades. } \\
\text { Adequar as produções às normas de bem estar } \\
\text { animal. }\end{array}$ & $\begin{array}{l}\text { - } \quad \text { Recuperar pastagens degradadas. } \\
\text { - } \quad \text { Criar um selo certificador da produção goiana. } \\
\text { Distribuir e incentivar o uso de cartilhas que contemplem ações voltadas } \\
\text { ao bem estar animal. } \\
\text { - } \text { Realizar encontros e palestras relativos ao tema. }\end{array}$ \\
\hline 7. Micro e pequenas empresas & $\begin{array}{l}\text { - Fomentar a maior participação de micro e pequenas } \\
\text { empresas ao longo da cadeia. }\end{array}$ & $\begin{array}{l}\text { - Promover programas de adequação de micro e pequenos fornecedores de } \\
\text { bens e serviços para serem capazes de atender grandes clientes. } \\
\text { - Buscar linhas de financiamento para modernização de pequenas e médias } \\
\text { industrias }\end{array}$ \\
\hline $\begin{array}{l}\text { 8. Fortalecimento dos elos } \\
\text { fracos e inexistentes }\end{array}$ & $\begin{array}{l}\text { - Atrair indústrias de produção de insumos tanto para } \\
\text { o campo quanto para os frigoríficos, para o estado de } \\
\text { Goiás. }\end{array}$ & 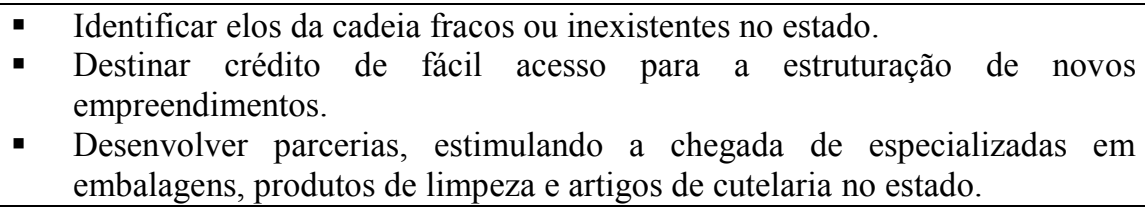 \\
\hline
\end{tabular}




\subsection{Carne de frango e carne suína}

As cadeias de carne suína e de frango do estado de Goiás apresentam características muito semelhantes tanto na sua estrutura interna quanto na sua situação externa. Devido a este fator, após análise detalhada das principais variáveis que as circundam, optou-se por apresentar seus problemas e projetos estratégicos de forma conjunta. Esta forma de apresentação não compromete o planejamento de nenhuma das duas cadeias, uma vez que seus direcionamentos são semelhantes e, se feitos em conjunto, podem ganhar mais força e trazer a elas ainda mais benefícios.

\subsubsection{Introdução às cadeias}

Com o constante crescimento da população mundial nas mais diversas partes do mundo, a demanda por alimentos vem aumentando proporcionalmente. Países como a Índia e China crescem em ritmo acelerado e há alguns anos vivenciam uma redistribuição de renda que permite níveis de consumo mais elevados. Neste cenário, o mercado de carnes suína e de frango tem crescido exponencialmente, suprindo parte da demanda por alimentos, principalmente por proteínas.

A carne suína é a proteína animal mais consumida no mundo, seguida pela carne de frango. No ano de 2012, foram consumidas mundialmente cerca de 105 milhões de toneladas de carne suína e 81 milhões de carne de frango, sendo que o principal país consumidor de ambas foi a China (UNITED STATES, 2013).

Apesar de a carne suína ser a principal carne consumida, nos últimos dez anos seu consumo mundial cresceu em torno de 19\%, número relativamente baixo quando comparado aos $41 \%$ observados na carne de frango, porém muito superior aos $4 \%$ da carne bovina (UNITED STATES, 2013). Seguindo esta tendência, estima-se que em poucos anos a carne de frango será a mais consumida mundialmente.

Segundo dados do UNITED STATES (2013), acompanhando os dados de consumo, a produção mundial de carne de frangos cresceu cerca de $42 \%$ nos últimos dez anos, atingindo em 2012 uma quantidade produzida de 83 milhões de toneladas. No mesmo ano, os Estados 
Unidos figuraram como principal produtor mundial de frangos de corte, respondendo por aproximadamente $19 \%$ da produção, seguido da China (16\%) e do Brasil (15\%).

Dado o acelerado crescimento da população mundial em países que buscam consumir proteínas animais de menor valor agregado, esse cenário tende a ser invertido já que entre 2002 e 2012 a produção de frangos do EUA cresceu cerca de 15\%, enquanto o crescimento chinês foi de $43 \%$ e o brasileiro, de 70\% (UNITED STATES, 2013).

A partir destes números e das projeções do Ministério da Agricultura, Pecuária e Abastecimento que estabelecem que a produção de carne de frango brasileira irá aumentar em torno de $56 \%$ nos próximos 10 anos e a de suínos $22 \%$, fica evidente que o país será um dos principais fornecedores desse tipo de proteína para o mundo em um futuro próximo (BRASIL, 2012a).

Atualmente, o Brasil é o maior exportador mundial de carne de frango, tendo exportado 3,5 milhões de toneladas em 2012 e o quarto maior exportador de carne suína, contabilizando 650 mil toneladas exportadas no mesmo ano (UNITED STATES, 2013). Os principais destinos de suas exportações de carne suína foram Ucrânia, Rússia e Hong Kong, representando 70\% do mercado internacional brasileiro (BRASIL, 2013a).

A China é um dos países com a população que mais cresce atualmente e nos últimos dez anos teve um aumento de $24 \%$ em sua demanda por carne suína e $41 \%$ em sua demanda por carne de frango. No Brasil, esses valores chegaram a $38 \%$ e $76 \%$ respectivamente, no mesmo período, o que mostra também o grande potencial de fortalecimento do consumo interno desses produtos (UNITED STATES, 2013).

O Brasil deve investir fortemente na criação e fortalecimento de relações internacionais para manter ou até aumentar sua penetração no mercado externo, porém também deve investir esforços no fortalecimento do produto no mercado interno, que é muito promissor.

\subsubsection{Importância do setor para Goiás}

As cadeias de carne suína e de frango de Goiás apresentam diversos aspectos semelhantes. Com caráter altamente industrial, contam com o sistema de contratos de integração entre produtores e indústrias, o que indica o alto grau de verticalização da produção. 
A produção de aves do estado de Goiás conta com aproximadamente 44 milhões de cabeças, valor que contempla frangos, galinhas, galos e pintos; já para os suínos, o estado possui mais de dois milhões de cabeças. Grande parte dessas produções está concentrada na região sudeste do estado (BRASIL, 2013c).

Com relação à evolução dos abates no estado, a carne de frango teve melhor desempenho relativo no último ano.

O estado figurou no último trimestre de 2013 como o sexto estado que mais abateu frangos do País, obtendo crescimento de 2,7\% nos abates com relação ao mesmo período do ano anterior. Os estado que mais abateram nesse período foram Paraná, com crescimento de 11,5\% em um ano, e Santa Catarina, com 28,2\% de crescimento. Para os abates suínos, o estado não obteve tão bom desempenho no último ano. Enquanto os maiores produtores do País, Santa Catarina e Rio Grande do Sul aumentaram seus abates em 0,4\% e 8,3\% respectivamente, Goiás teve uma queda de 10,6\% na atividade (BRASIL, 2013b)

Quanto às exportações, no ano de 2012 a carne de frango trouxe resultados de R $\$ 406$ milhões de dólares para o estado, sendo que o principal destino foi a Arábia Saudita (13\% do volume total), seguido de Hong Kong (11\% do volume total) e da China (10\% do volume total). Já para a carne suína, Goiás exportou seu produto para 19 países, tendo gerado US\$185 milhões no de 2012, sendo a Rússia seu principal destino, com $70 \%$ do volume total exportado (BRASIL, 2013a).

Apesar de estarem presentes no território goiano, alguns elos ainda necessitam de fortalecimento, como é o caso dos fornecedores de insumos e serviços para a atividade. A Tabela 2 a seguir, mostra a relação de estabelecimentos pertencentes a este elo no estado.

Tabela 2 - Relação de estabelecimentos de apoio à produção de aves e suínos no estado de Goiás Relação de estabelecimentos (CNAE)

Atividade (apoio à produção)

Fabricação de alimentos para animais

\begin{tabular}{lc} 
Fabricação de alimentos para animais & 138 \\
\hline Fabricação de embalagens de papel & 23 \\
\hline Fabricação de embalagens de cartolina e papel-cartão & 3 \\
\hline Fabricação de aditivos de uso industrial & 6 \\
\hline Fabricação de medicamentos para uso veterinário & 11 \\
\hline Fabricação de máquinas e equipamentos para agricultura e pecuária, exceto para irrigação & 36 \\
\hline Fabricação de máquinas e equipamentos para as indústrias de alimentos, bebida e fumo & 14 \\
\hline $\begin{array}{l}\text { Comércio atacadista de animais vivos, alimentos para animais e matérias-primas agrícolas, } \\
\text { exceto café e soja }\end{array}$ & 192 \\
\hline Comércio atacadista de máquinas, aparelhos e equipamentos para uso agropecuário & 89 \\
\hline Atividades (serviços) & \\
\hline Atividades veterinárias & 51 \\
\hline Serviços de catering, buffet e outros serviços de comida preparada & 273 \\
\hline Representantes comerciais e agentes do comércio de matérias-primas agrícolas e animais & 53 \\
\hline
\end{tabular}




\begin{tabular}{l|c}
\hline vivos & \\
\hline Transporte rodoviário de carga & 2446 \\
\hline Atividades auxiliares dos transportes terrestres não especificadas anteriormente & 122 \\
\hline
\end{tabular}
Fonte: BRASIL, 2010

Como pode ser constatado com os dados apresentados, a fabricação de embalagens, medicamentos veterinários, aditivos de uso industrial, máquinas e equipamentos ainda é muito pequena no estado de Goiás, sendo que sua grande concentração ocorre em outros estados como São Paulo, Minas Gerais e em alguns estados da região sul do País (BRASIL, 2010).

Com o fortalecimento desses setores no estado, o custo de produção poderia ser reduzido, e a economia goiana movimentada como um todo com a geração de empregos, estímulo da chegada de novas indústrias correlatas, entre outras consequências.

A grande disponibilidade de grãos, alta qualidade sanitária de seus animais e grande acesso a mercados internacionais indicam que ainda existe muito espaço de crescimento da produção de carne suína e de frango em Goiás.

\subsubsection{Análise dos principais problemas}

A partir das análises realizadas na execução do método e das entrevistas com especialistas, foram identificados diversos problemas para as cadeias produtivas de carne suína e de frango do estado de Goiás. Os principais problemas são pontuados no Quadro 10, servindo de direcionadores para a determinação do posicionamento estratégico da cadeia no estado e das ações estratégicas a serem tomadas.

Quadro 10 - Principais problemas encontrados na cadeia de aves e suínos do estado de Goiás.

\begin{tabular}{|c|}
\hline $\begin{array}{l}\text { - Os estados da região Sul são grandes concorrentes do estado por possuírem forte cultura } \\
\text { cooperativista, alto nível tecnológico, grande disponibilidade de grãos e um dos melhores sistemas de } \\
\text { controle sanitário do país. }\end{array}$ \\
\hline - As exportações possuem baixo valor agregado, gerando vantagem competitiva para os concorrentes. \\
\hline $\begin{array}{l}\text { - A indústria processadora tem alto poder de barganha frente aos produtores, uma vez que são } \\
\text { concentradas e firmam contratos de produção integrada rígidos. }\end{array}$ \\
\hline $\begin{array}{l}\text { - Há uma grande dependência da safra de grãos para o estabelecimento das atividades, uma vez que eles } \\
\text { são a base da alimentação animal. }\end{array}$ \\
\hline - $\quad$ Ausência de mão de obra qualificada. \\
\hline $\begin{array}{l}\text { - Grandes problemas de logística devido as más condições de estradas e rodovias e a grande } \\
\text { dependência por esse modais. }\end{array}$ \\
\hline - $\quad$ Necessidade de um fortalecimento da imagem das carnes suína e de frangos junto ao consumidor final. \\
\hline - Obsolescência tecnológica em alguns pontos da cadeia. \\
\hline $\begin{array}{l}\text { - Alta produção de dejetos, principalmente para suínos, necessitando medidas } \\
\text { para destinação dos mesmos. }\end{array}$ \\
\hline
\end{tabular}


- Presença de abatedouros clandestinos, com fiscalização deficiente.

- Mercado consumidor local relativamente pequeno frente à sua oferta.

- Necessidade de maiores investimentos em Pesquisa e Desenvolvimento.

Fonte: Elaborado pelo autor.

O posicionamento estratégico que as cadeias devem buscar até 2020 e que foi determinado a partir da avaliação dos principais problemas da cadeia no estado seguem duas linhas principais: o aumento do volume de produção mediante investimento em novas tecnologias e melhores administrações das produções, associadas a um maior nível de coordenação vertical, que contribuirá para o alinhamento de objetivos e estratégias entre os diversos elos que compõe as cadeias produtivas analisadas.

\subsubsection{Missão, visão, objetivos e ações estratégicas para o setor no estado}

\subsubsection{Missão e visão da cadeia}

\section{Missão}

Produzir aves e suínos com qualidade, segurança e sustentabilidade, aumentando a produção com plena coordenação entre os agentes para atender às necessidades alimentares das pessoas, no Brasil e no mundo.

\section{Visão}

Ser o melhor produtor de aves e suínos do Brasil, tornando-se a maior referência nacional em qualidade e segurança, por meio do uso das mais modernas tecnologias de produção, e consolidando o estado entre os mais produtivos, competitivos e sustentáveis.

\subsubsection{Objetivos e ações estratégicas}

De acordo com os problemas identificados e os posicionamentos estratégicos almejados, os objetivos e ações estratégicas propostas para a cadeia produtiva de aves e suínos do estado de Goiás foram divididos em oito dimensões: Produção, produtos, pesquisa e inovação; Comunicação; Distribuição, logística e exportações; Capacitação e recursos humanos; Coordenação e adequação ao ambiente institucional; Sustentabilidade; Micro e 
pequenas empresas; e Fortalecimento dos elos fracos e inexistentes. No Quadro 11 são organizadas essas dimensões e seus respectivos objetivos e ações estratégicas. 
Quadro 11 - Planos vetores estratégicos, objetivos e ações estratégicas propostas para as cadeias de carne suína e de frango do estado de Goiás.

\begin{tabular}{|c|c|c|}
\hline Planos Vetores Estratégicos & Objetivos & Ações Estratégicas \\
\hline 2. Comunicação & $\begin{array}{l}\text { - Aumentar o consumo interno de carne de frango e } \\
\text { suína. } \\
\text { - Aumentar a participação do Brasil nas exportações } \\
\text { mundiais desses produtos. } \\
\text { Melhorar a comunicação inter e entre elos das } \\
\text { cadeias. }\end{array}$ & $\begin{array}{l}\text { - Quantificar e mapear as cadeias divulgando os resultados e benefícios } \\
\text { gerados para a sociedade. } \\
\text { Incentivar o posicionamento de "produtores modelo" para realização de } \\
\text { dias-de-campo propiciando benchmarking na cadeia. } \\
\text { - Criar um meio de comunicação que agregue o setor e chegue até os } \\
\text { produtores. }\end{array}$ \\
\hline $\begin{array}{l}\text { 3. Distribuiçãc } \\
\text { exportações }\end{array}$ & $\begin{array}{l}\text { Reduzir custos logísticos para o estado. } \\
\text { Estruar centrais de compras para pequenos produtores. } \\
\text { eficiente. }\end{array}$ & $\begin{array}{l}\text { Melhorar as condições e manutenção de estradas vicinais. } \\
\text { Propiciar melhorias na logística de produtos perecíveis e na cadeia do frio. } \\
\text { pessibibilitar o aprovertitamento de fretes. }\end{array}$ \\
\hline & - $\mathrm{Fo}$ & \\
\hline Humanos & $\begin{array}{l}\text { - Adequar o trabalho presente em todos os elos das } \\
\text { cadeias à legislação trabalhista vigente. } \\
\text { - Reduzir a rotatividade de mão de obra das cadeias. }\end{array}$ & $\begin{array}{l}\text { - Promover visitas de cooperação técnica internacional propiciando uma } \\
\text { visão global de diferentes formas de produçãa. } \\
\text { - Incentivar a inclusão digital dos produtores. }\end{array}$ \\
\hline 7. Micro e pequenas empresas & $\begin{array}{l}\text { - Estimular inclusão de produtores familiares nas } \\
\text { cadeias. } \\
\text { - Elevar o acesso de micro e pequenas empresas ao } \\
\text { crédito agrícola. }\end{array}$ & $\begin{array}{l}\text { - Criar cooperativas para pequenos produtores, pequenas indústrias e } \\
\text { varejistas. } \\
\text { - Incentivar compras e vendas conjuntas de pequenos e médios produtores. } \\
\text { - Melhorar incentivos para pequenos e médios produtores. }\end{array}$ \\
\hline $\begin{array}{l}\text { 8. Fortalecimento dos elos } \\
\text { fracos e inexistentes }\end{array}$ & $\begin{array}{l}\text { Fortalecer as indústrias produtoras de insumos do } \\
\text { Estado e estimular a instalação de indústrias de } \\
\text { insumos não existentes no estado. }\end{array}$ & $\begin{array}{l}\text { - Aumentar o fornecimento local de produtos veterinários, máquinas, } \\
\text { equipamentos e embalagens por meio do incentivo à instalação denovas } \\
\text { indústrias no estado. }\end{array}$ \\
\hline
\end{tabular}

Fonte: elaborado pelo autor. 


\subsection{Lácteos}

\subsubsection{Introdução à cadeia}

O mercado de leite e seus derivados tem seguido a tendência de crescimento dos setores relacionados com a alimentação, uma vez que a população mundial vem aumentando e demandando maiores volumes de alimentos. Nos últimos 11 anos, tanto a produção quanto o consumo desse setor se elevou mais de 40\% (UNITED STATES, 2013).

Apesar dos aumentos de produção e consumo, o tamanho do rebanho leiteiro mundial manteve-se estável, indicando que os ganhos foram em produtividade.

O rebanho leiteiro da Índia é o maior do mundo, contabilizando 46 milhões de cabeça, enquanto que o brasileiro, com cerca de 20 milhões de cabeças, posiciona-se em terceiro lugar, atrás da União Europeia, que tem 23 milhões de cabeças, (UNITED STATES, 2013).

Apesar do grande rebanho, a Índia ocupa a segunda colocação quando se trata de produção de leite (129 milhões de toneladas), ficando atrás da União Europeia com seus 144 milhões de toneladas produzidas em 2012. O Brasil por sua vez, cai para o sexto lugar, tendo produzido 31 milhões de toneladas (UNITED STATES, 2013).

O consumo mundial de leite se equivale à sua produção, uma vez que no ano de 2012 foram produzidas e consumidas 544,5 milhões de toneladas do produto. O país que mais consome o leite e seus derivados é a própria União Europeia, seguida da Índia e Estados Unidos. O Brasil ocupa a sexta colocação dos maiores consumidores mundiais de leite (UNITED STATES 2013).

Outra maneira de analisar o consumo de alimentos é por meio do seu consumo per capita, que relaciona o volume consumido com a população que o consumiu. O país com maior consumo per capita do mundo no ano de 2012 foi a Austrália, contabilizando cerca de $150 \mathrm{~kg} / \mathrm{hab} /$ ano. O Brasil aparece em sétimo lugar (88 kg/hab./ano) atrás de países como a Ucrânia, Canadá, Estados Unidos, Rússia e União Europeia (UNITED STATES, 2013).

Frente ao volume de leite mundialmente produzido, as exportações e importações representam pequena fatia $(0,1 \%)$. Quanto às exportações, no ano de 2012 foram exportados mundialmente em torno de 613 mil toneladas de leite sendo a União Europeia (58\%) e a Nova Zelândia (16\%) responsáveis por 74\% desse volume. Apesar de o Brasil já ter sido o quarto maior exportador mundial de leite (2008), atualmente não está nas primeiras colocações, figurando como o sétimo maior importador mundial do produto. (UNITED STATES, 2013). 
Dentre os países importadores, apenas cinco países concentram mais de $94 \%$ do volume total importado. A Rússia ocupa a primeira colocação nas importações seguida pela China, Filipinas, México e Canadá (UNITED STATES, 2013).

Apesar da sua alta aptidão para produção de leite, o Brasil ainda possui um saldo negativo na balança comercial, tendo importado em 2012 aproximadamente 111 mil toneladas do produto (cru, em pó, queijo e manteiga) e exportado apenas seis toneladas (UNITED STATES, 2013), como mostra a Tabela 3. O País importa grande parte do produto de seus parceiros comerciais do Mercosul como Uruguai, Argentina e Chile (BRASIL, 2013a).

Tabela 3 - Exportações e importações brasileiras de leite e derivados em 2012

\begin{tabular}{c|c|c}
\hline & Exportações (1.000 ton) & Importações (1.000 ton) \\
\hline Leite Cru & 0 & 12 \\
Leite em Pó & 1 & 71 \\
Queijo & 3 & 27 \\
Manteiga & 2 & 1 \\
\hline TOTAL & 6 & 111 \\
\hline \multicolumn{2}{|c}{ Fonte: Elaborado pelo autor, a partir de UNITED STATES, 2013. }
\end{tabular}

No Brasil, os maiores rebanhos leiteiros estão localizados no estado de Minas Gerais e no sul do País. Em 2012, o estado que mais produziu leite foi Minas Gerais, com uma produção de 8,9 bilhões de litros. Goiás figurou na quarta colocação, com um volume de 3,6 bilhões de litros (BRASIL, 2013c). A Tabela 4 mostra os principais estados produtores do país com seus níveis de produtividade.

Tabela 4 - Produção e produtividade dos principais estados produtores de leite do Brasil em 2012

\begin{tabular}{c|c|c|c}
\hline Estado & $\begin{array}{c}\text { Vacas Ordenhadas (cabeças) } \\
\mathbf{- 2 0 1 2}\end{array}$ & $\begin{array}{c}\text { Quantidade (1000 litros) - } \\
\mathbf{2 0 1 2}\end{array}$ & $\begin{array}{c}\text { Produtividade } \\
\text { (10001/cabeça) }\end{array}$ \\
\hline MG & 5.674 .293 & 8.905 .984 & 1,57 \\
RS & 1.516 .689 & 4.049 .487 & 2,67 \\
PR & 1.615 .916 & 3.968 .506 & 2,46 \\
GO & 2.692 .841 & 3.546 .329 & 1,32 \\
SC & 1.078 .118 & 2.717 .651 & 2,52 \\
\hline
\end{tabular}

Fonte: Elaborado pelo autor a partir de BRASIL 2013c

O sul do País apresentou, nos últimos anos, um grande aumento da sua produção e produtividade. Este fato é devido aos altos investimentos em tecnologia e melhoramento genético, sendo que a região desenvolveu um rebanho muito adaptado aos seus fatores ambientais. Apesar dessa evolução, muito ainda deve ser trabalhado nessa cadeia para elevar ainda mais seus níveis de produtividade. O potencial da atividade fica evidente quando se 
analisam os dados dos Estados Unidos, país mais produtivo na atividade, que atingiu a marca de 9,83 litros/vaca/ano em 2012 (UNITED STATES, 2013).

No ano de 2012, dos 32 bilhões de litros de leite cru produzidos no Brasil, 69\% foram adquiridos por unidades de processamento que atuam sob inspeção sanitária federal $(92,5 \%)$, estadual $(6,8 \%)$ ou municipal (0,7\%) (BRASIL, 2013b).

$\mathrm{O}$ aquecimento da economia brasileira tem aumentado a demanda por produtos como o leite e seus derivados e a produção não está acompanhando esse crescimento, resultando no aumento das importações já comentado anteriormente. Segundo projeções, até o ano de 2022 o consumo nacional de leite aumentará cerca de $20 \%$ e o País deverá estar pronto para atender a essa demanda (BRASIL, 2012a).

\subsubsection{Importância do setor para Goiás}

Goiás figura como o quarto maior produtor de leite do País, sendo que a sua cadeia é mais concentrada no centro-sul do estado (BRASIL, 2013c). O Gráfico 1, a seguir, mostra a produção de 2012 e a quantidade industrializada dos principais estados produtores.

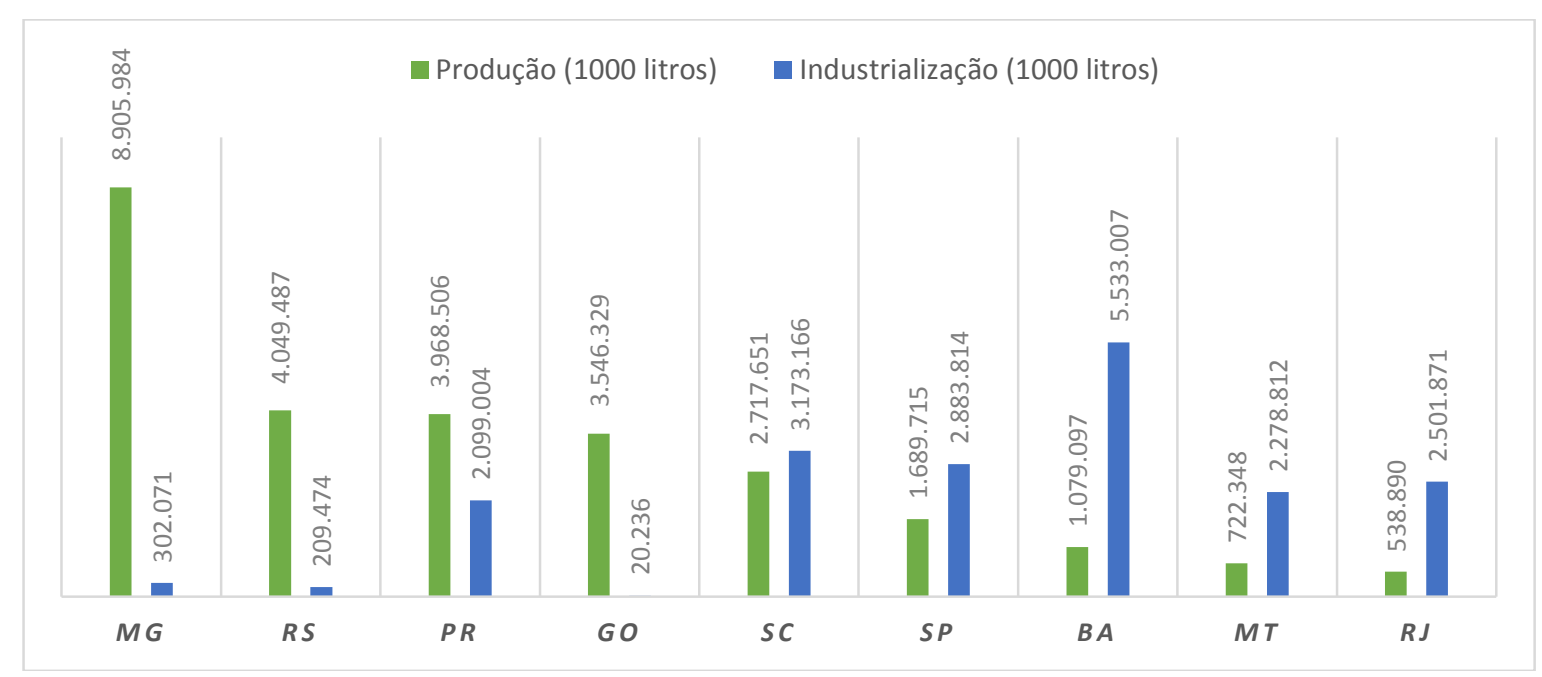

Gráfico 1 - Produção e industrialização de leite por estado no ano de 2012. Fonte: Elaborado pelo autor, a partir de BRASIL, 2013b e BRASIL, 2013c

Dos cinco maiores produtores de leite, apenas Santa Catarina figura também entre os cinco maiores processadores do produto. O estado de Goiás, apesar de contar com mais de 160 empresas envolvidas na produção de lácteos, ainda possui níveis de industrialização muito baixos frente a sua produção, o que indica que seu produto é vendido com pouco valor agregado. A maior concentração destas indústrias no estado está nos pequenos ou médios 
estabelecimentos. Outro problema enfrentado pelo estado é a alta ociosidade industrial que chega a atingir 50\%, mesmo possuindo um parque industrial moderno (FAEG, 2009; BRASIL, 2007).

Com relação à remuneração do produto, ao analisar apenas a remuneração/cabeça, comparativamente com os quatro maiores estados produtores, Goiás obteve o menor índice no ano de 2012, o que pode ser interpretado como uma necessidade de aumento de sua produtividade e agregação de valor ao seu produto. A Tabela 5 mostra os cinco maiores estados produtores de leite e a remuneração obtida por vaca ordenhada no ano de 2012.

Tabela 5 - Remuneração por vaca ordenhada no ano de 2012

\begin{tabular}{c|c|c|c}
\hline Estado & Vacas Ordenhadas (cabeças) & $\begin{array}{c}\text { Remuneração } \\
\mathbf{( 1 0 0 0 ~ R \$ )}\end{array}$ & $\begin{array}{c}\text { Remuneração/cabeça } \\
\mathbf{( 1 0 0 0} \mathbf{R \$})\end{array}$ \\
\hline MG & 5.674 .293 & 7.479 .796 & 1,32 \\
RS & 1.516 .689 & 3.088 .230 & 2,04 \\
PR & 1.615 .916 & 3.213 .682 & 1,99 \\
GO & 2.692 .841 & 2.784 .406 & 1,03 \\
SC & 1.078 .118 & 2.145 .805 & 1,99 \\
\hline
\end{tabular}

Fonte: Elaborado pelo autor, a partir de dados BRASIL, 2013c.

Porém em uma análise de custos, em que são considerados o custo de produção e o preço da terra, nota-se que o estado de Goiás apresenta vantagens financeiras para a atividade. O Gráfico 2 mostra a comparação do Custo Operacional Efetivo, do preço pago ao produtor e do valor da terra nos estados de MG, RS, SC e GO.

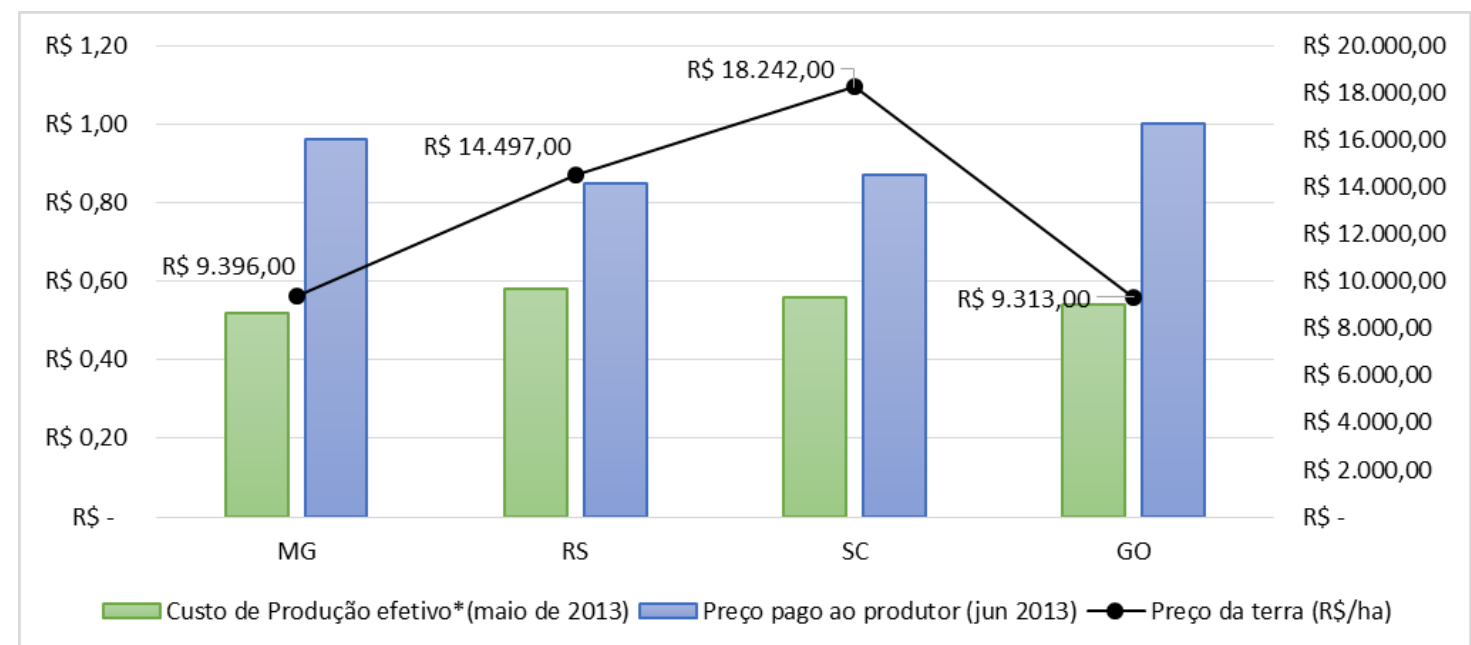

Gráfico 2 - Custo de produção efetivo, preço da terra e preço pago ao produtor de leite em 2013.

Fonte: Elaborado pelo autor, a partir de CONAB, 2013b; CEPEA, 2013; INFORMA ECONOMICS, 2013 * MG = Bambuí; RS = Ijuí; SC = Rio do Sul; GO = Orizona. 
Ainda com relação à remuneração, estados como Santa Catarina, Paraná, Rio Grande do Sul e Mato Grosso do Sul já possuem um sistema chamado Conseleite, que busca amenizar as diferenças entre produtores e indústria mediante a fixação de um preço-referência a ser pago ao produtor (ABUD; LIMA, 2009).

Ademais, o Conseleite, com suas especificidades para cada estado, estabelece preços de referência levando em consideração a qualidade do leite entregue. No estado de Goiás, existem apenas estudos para a implantação de um sistema como esse, que poderia contribuir muito para a remuneração do produtor e seu maior alinhamento com a indústria (ABUD; LIMA, 2009).

Com relação à assistência técnica no campo, uma pesquisa realizada pela Federação da Agricultura e Pecuária de Goiás constatou que, em 2008, mais de $80 \%$ dos 500 produtores entrevistados não recebiam assistência técnica contínua, e a existente foi, na grande maioria (75\%), oriunda de instituições particulares como laticínios, cooperativas e empresas de insumos (FAEG, 2009).

A partir desses fatos, nota-se que a produção de leite goiana ainda pode ser muito desenvolvida. O estado ainda conta com falta de assistência técnica, inexistência de políticas eficazes de renda, dificuldades em gerenciamento de custos, gerenciamento de riscos da atividade e desestimulo ao produtor (FAEG, 2009). No campo, os níveis de produtividade ainda têm muito espaço para crescer, porém devem ser destinados investimentos para o processamento do produto no estado, para agregar valor ao seu leite produzido e conquistar cada vez mais mercados.

\subsubsection{Análise dos principais problemas}

O Quadro 12 mostra os principais problemas encontrados na cadeia de leite e seus derivados do estado de Goiás. Os problemas identificados servirão de base para traçar o posicionamento e as ações estratégicas.

Quadro 12 - Principais problemas encontrados na cadeia de lácteos do estado de Goiás.

- A produção de leite é muito pulverizada, com a presença de uma grande quantidade de produtores espalhados geograficamente e sem organização.

- Goiás está mais distante dos principais centros consumidores (Rio de Janeiro, São Paulo e Belo Horizonte) do que seus principais concorrentes (FAEG, 2009).

- Outras regiões do país e do mundo possuem maior número e melhor estruturação industrial. 


\begin{tabular}{|c|}
\hline $\begin{array}{l}\text { - Os insumos para a produção animal vêm tendo seus preços elevados. } \\
\text { - } \\
\text { fornecedores de insumos. } \\
\text { forna coordenac̃o dos produtores reduzindo seu poder de barganha frente aos }\end{array}$ \\
\hline $\begin{array}{l}\text { - Concentração de redes varejistas e de grandes produtores, que reduz o poder de } \\
\text { barganha do pequeno e médio produtor e processador não coordenado. }\end{array}$ \\
\hline - Necessidade de estímulo do consumo por meio de ações promocionais. \\
\hline - Competitividade dependente dos custos de produção, que vêm crescendo ano a ano. \\
\hline $\begin{array}{l}\text { - Necessidade de uma economia de escala para viabilizar novos polos de } \\
\text { processamento de leite. }\end{array}$ \\
\hline $\begin{array}{l}\text { - Baixa fidelização dos consumidores em produtos altamente padronizados como o } \\
\text { leite UHT. }\end{array}$ \\
\hline $\begin{array}{l}\text { Entrada de muitos produtos substitutos no mercado como bebidas a base de soja, } \\
\text { enriquecidas com cálcio, entre outras que possuem grande poder de marketing. }\end{array}$ \\
\hline $\begin{array}{l}\text { - O aumento das importações do produto está reduzindo as margens da produção } \\
\text { nacional, que possui altos custos de produção. }\end{array}$ \\
\hline - Necessidade de melhoria da qualidade do leite para atender mercados mais exigentes. \\
\hline $\begin{array}{l}\text { - Produtos sujeitos a forte sazonalidade no país, tendo significativos aumentos de } \\
\text { preços nos meses de maio a setembro. }\end{array}$ \\
\hline $\begin{array}{l}\text { - O estado não consegue abastecer plenamente as indústrias com seu leite produzido, } \\
\text { tendo uma captação de leite abaixo da esperada. As indústrias possuem alta } \\
\text { capacidade ociosa. }\end{array}$ \\
\hline $\begin{array}{l}\text { - A produção enfrenta altos custos logísticos devido a sua grande dependência do } \\
\text { modal rodoviário. }\end{array}$ \\
\hline - Poucos fornecedores locais de embalagens. \\
\hline - Alta burocracia para acesso ao crédito. \\
\hline $\begin{array}{l}\text { - Falta de parcerias entre indústrias de diferentes segmentos (que também usam o leite } \\
\text { como matéria prima) e produtores. }\end{array}$ \\
\hline - Alta carga tributária para insumos industriais. \\
\hline $\begin{array}{l}\text { - Necessidade de maiores níveis tecnológicos na produção de leite e concomitante } \\
\text { quebra da resistência do produtor a adotar essas tecnologias para aumento de } \\
\text { produtividade. }\end{array}$ \\
\hline - Grande carência de capacitação e qualificação de mão de obra. \\
\hline - Incentivos para a indústria são melhores que para os produtores. \\
\hline - Necessidade e espaço para aumento de produtividade na atividade. \\
\hline $\begin{array}{l}\text { - Caráter artesanal e pulverizado da produção influencia na qualidade do produto } \\
\text { deixando-a baixa e irregular. }\end{array}$ \\
\hline $\begin{array}{l}\text { - Tipo de transações entre produtores e indústria propicia falta de contratos e garantias } \\
\text { para ambos. }\end{array}$ \\
\hline
\end{tabular}
Fonte: Elaborado pelo autor.

A partir dos problemas levantados, foi sugerido o posicionamento estratégico para a cadeia de leite e seus derivados do estado de Goiás, ou seja, foi estabelecido como a cadeia goiana quer ser enxergada por seus consumidores em 2020. O posicionamento almejado serve de direcionamento para estabelecer os objetivos e ações estratégicas. 
O estado deve buscar dois aspectos básicos para atingir seu posicionamento almejado. Por um lado, deve buscar melhores níveis de assistência técnica que propiciem o aumento da qualidade do produto, transferência de tecnologia e assistência à gestão das propriedades. Por outro, o estado deve buscar aumentar a rentabilidade do setor por meio da redução de custos (escala), agregação de valor ao seu produto (processamento) e abertura de novos mercados (comercialização) para desta maneira, manter os atuais participantes da cadeia no estado e atrair novos investimentos.

\subsubsection{Missão, visão, objetivos e ações estratégicas para o setor no estado}

\subsubsection{Missão e visão da cadeia}

\section{Missão}

Produzir leite e derivados com qualidade, segurança e sustentabilidade, que atendam às necessidades das pessoas no Brasil e no mundo.

\section{Visão}

Ser o melhor produtor de leite e derivados do Brasil, consolidando a produção do estado com qualidade, competitividade e sustentabilidade e contribuindo para o desenvolvimento da economia goiana.

\subsubsection{Objetivos e ações estratégicas}

De acordo com os problemas identificados e os posicionamentos estratégicos almejados, os objetivos e ações estratégicas propostas para a cadeia de leite e seus derivados do estado de Goiás foram divididos em oito dimensões: Produção, produtos, pesquisa e inovação; Comunicação; Distribuição, logística e exportações; Capacitação e recursos humanos; Coordenação e adequação ao ambiente institucional; Sustentabilidade; Micro e pequenas empresas; e Fortalecimento dos elos fracos e inexistentes. No Quadro 13, são organizadas essas dimensões e seus respectivos objetivos e ações estratégicas. 
Quadro 13 - Planos vetores estratégicos, objetivos e ações estratégicas propostas para a cadeia de leite e seus derivados do estado de Goiás.

Planos Vetores Estratégicos

1. Produção, produtos, pesquisa e inovação

2. Comunicação

\begin{abstract}
3. Distribuição, logística e
\end{abstract} exportações

\begin{tabular}{l} 
4. Capacitação/Recursos \\
Humanos \\
\hline 5. Coordenação e adequação \\
ao ambiente institucional
\end{tabular}

6. Sustentabilidade

6. Sustentabilidade
7. Micro e pequenas empresas
Objetivos
- Aumentar a produção de leite no estado e reduzir a
capacidade ociosa industrial.

- Aumentar de forma padronizada a qualidade do leite de Goiás.

- Desenvolver e difundir novas tecnologias.

- Consolidar a imagem do leite Goiano como um produto da mais alta qualidade.

- Ampliar a penetração dos produtos goianos no mercado nacional.

- Melhorar a comunicação e troca de conhecimentos inter e entre elos da cadeia.

- Reduzir custos logísticos para o escoamento da produção no estado.

- Criar um centro integrador logístico.

- Estruturar o abastecimento de leite às indústrias por meio de parcerias e contratos.

- Capacitar e qualificar a mão de obra demandada pela cadeia.

- Reduzir a rotatividade de mão de obra.

- Adequar o trabalhador do estados à legislação.

- Aumentar os níveis de coordenação na cadeia.

- Implementar sistema de inteligência que agregue todo os elos da cadeia.

- Incentivar a instalação de novas empresas no estado.

- Aumentar a sustentabilidade de toda a cadeia.

- Criar um selo de produto sustentável para a promoção do produto goiano.

- Fortalecer os micro e pequenos empresários presentes na cadeia de leite e seus derivados no estado.

8. Fortalecimento dos elos fracos e inexistentes

- Fortalecer as indústrias produtoras de insumos do Estado e estimular a instalação de indústrias de insumos não existentes no estado

\section{Ações Estratégicas}

- Promover o aumento da produtividade por meio do uso eficiente dos recursos e a adoção de tecnologias, com o amplo apoio de uma rede de assistência técnica.

- Disseminar os resultados da pesquisa de novos produtos e novas tecnologias para os produtores e para as indústrias.

- Divulgar pesquisas que mostrem os benefícios dos produtos lácteos e seus derivados.

- Articular junto ao governo federal um programa de posicionamento da cadeia de leite brasileira.

- Promover eventos que levem os produtores para um mesmo local onde possam realizar troca de informações.

- Melhorar os serviços de manutenção de estradas.

- Incentivar a renovação e manutenção da frota de veículos adaptados ao transporte de produtos lácteos.

- Reestruturar os produtores de leite do estado em arranjos produtivos locais próximos às indústrias.

- Expandir e incentivar o acesso aos cursos de capacitação e qualificação de mão de obra.

- Incentivas a extensão do conhecimento e tecnologia das universidades para os produtores por meio de eventos e parcerias com o estado e a industria.

- Definir um grupo de gestão responsável pela coordenação de um sistema de governança da cadeia produtiva do leite.

- Elaborar diretrizes junto aos agentes da cadeia para novas políticas públicas para o setor.

- Criar um programa de certificação para a sustentabilidade ambiental e social no estado.

- Mapear recursos naturais do estado para prevenção de riscos ambientais.

- Fortalecer ou criar novas cooperativas para pequenos produtores, pequenas indústrias e estabelecimentos familiares.

- Incentivar centrais de compras e cooperativas de crédito para pequenos.

- Articular o incentivo ao aumento do mercado atacadista de fertilizantes.

Fortalecer e estimular a setor de serviços para agroindústrias de lácteos no estado. 


\subsection{Soja e Milho}

Da mesma maneira que as cadeias de carne suína e de frango do estado, as cadeias de soja e milho apresentam características muito semelhantes tanto na sua estrutura interna quanto na sua situação externa. Como feito para as carnes de frango e suína, os grãos (soja e milho) serão apresentados em conjunto. Esta forma de apresentação não compromete o planejamento de nenhuma das duas cadeias, uma vez que seus direcionamentos são semelhantes e, se feitos em conjunto, podem ganhar mais força e trazer-lhes ainda mais benefícios.

\subsubsection{Introdução às cadeias}

A soja e o milho são duas commodities de grande importância econômica mundial por serem elementos base da alimentação humana e animal, além de figurarem como matérias primas para diversas outras indústrias como a de biocombustíveis, por exemplo.

Nos últimos dez anos, a produção mundial de soja cresceu em torno de $36 \%$ contabilizando, em 2012, uma produção de 268 milhões de toneladas, já a produção de milho no mesmo ano foi de 863 milhões de toneladas, apresentando um aumento de $43 \%$ nos últimos dez anos.

Para a soja, os maiores produtores mundiais são, nessa ordem, Estados Unidos, Brasil, Argentina, China e Índia, detendo juntos $88 \%$ de toda área plantada e sendo responsáveis por $89 \%$ de todo volume produzido mundialmente; já para o milho, os maiores produtores são Estados Unidos (274 milhões de toneladas), China (206 milhões de toneladas) Brasil (80 milhões de toneladas) e União Europeia (59 milhões de toneladas), porém, enquanto os norteamericanos aumentaram sua produção em $20 \%$ nos últimos dez anos, a China contabilizou aumento de $70 \%$ e o Brasil, 82\% (UNITED STATES, 2013).

Quanto ao consumo, o aumento populacional mundial, melhor distribuição de renda e uso de grãos como matéria prima de novos setores proporcionaram um crescimento de $35 \%$ para a soja e $38 \%$ para o milho, nos últimos dez anos. No ano de 2012 , foram consumidas mundialmente 258 milhões de toneladas de soja e aproximadamente 865 milhões de toneladas de milho. O principal destino das exportações de soja foi a China, importando $60 \%$ do 
produto disponível no mercado internacional. Já para o milho, o principal país importador foi o Japão, tendo importado 15\% do produto em 2012 (UNITED STATES, 2013).

No tocante às previsões do setor, a demanda mundial pelos produtos crescerá em níveis acelerados devido, principalmente, ao aumento populacional. Estima-se que para a soja, a produção cresça em torno de $24 \%$ nos próximos dez anos e o consumo, cerca de $30 \%$ no mesmo período (OCDE, 2012).

Neste contexto, o Brasil figurou como o segundo maior produtor mundial de soja na safra 2012/1013, sendo responsável por 30\% da produção (82 milhões de toneladas) e como terceiro maior produtor de milho, contando com uma produção de 80 milhões de toneladas (UNITED STATES, 2013; CONAB, 2013a)

Uma característica da produção nacional de milho é que ela está difundida por todos os estados, porém em níveis tecnológicos distintos, tendo estados como alguns do Norte e Nordeste produção apenas para subsistência (BRASIL, 2007). Já para a soja, apenas 14 estados do País são produtores, e os quatro maiores são responsáveis por $74 \%$ da produção nacional (CONAB, 2013a).

Com relação à produtividade de grãos, o Brasil obteve importantes ganhos nos últimos anos. A Tabela 6 a seguir mostra a evolução da produtividade (ton/ha) da soja nos últimos 32 anos.

\begin{tabular}{|c|c|c|c|c|c|c|c|c|c|}
\hline & \multicolumn{9}{|c|}{ Produção/área (ton/ha) } \\
\hline & 1980 & 1985 & 1990 & 1995 & 2000 & 2005 & 2010 & 2012 & $\begin{array}{c}\text { \%1980- } \\
2012\end{array}$ \\
\hline Soja & 1,79 & 1,49 & 1,62 & 2,21 & 2,83 & 2,56 & 3,11 & 2,96 & $65 \%$ \\
\hline Milho & 1,76 & 1,59 & 1,80 & 2,36 & 3,20 & 3,23 & 4,16 & 5,13 & $191 \%$ \\
\hline
\end{tabular}

Fonte: Elaborado pelo autor a partir de CONAB, 2013a.

Como pode ser observado, a produtividade (ton/ha) para a soja saltou de 1,79 em 1980 para 2,96 em 2012, resultando em um ganho de 65\%. Para o milho, os números são ainda mais impressionantes, tendo sua produtividade alcançado um ganho da ordem de 191\% em 32 anos, atingindo 5,13 ton/ha. Essas produtividades podem ser comparadas às dos Estados Unidos, que chegaram na safra 2012/2013 a 2,69 para a soja e 7,74 para o milho (UNITED STATES, 2013).

Em torno de $67 \%$ das exportações de soja do País são no formato de grãos, indicando a oportunidade de exportações de produtos processados com maior valor agregado. O Brasil exportou em 2012 cerca de $40 \%$ da soja em grãos produzida e $25 \%$ do total de milho 
produzido. Na pauta de exportações do País, o complexo soja ocupa o primeiro lugar, enquanto o milho aparece em sétimo (UNITED STATES, 2013; BRASIL, 2013a).

De acordo com as previsões para o setor de grãos brasileiro, o País terá que aumentar ainda mais sua produção para suprir a demanda crescente pelo produto, tanto interna quanto externamente. Para a soja, estima-se que o consumo aumentará por volta de $22 \%$ enquanto as exportações aumentarão 32\%, nos próximos dez anos. Já para o milho, o consumo deve crescer 19\% e as exportações, 33\% (BRASIL, 2012a).

Produtores e demais agentes dessas importantes cadeias produtivas devem estar prontos para suprir o futuro aumento da demanda por seus produtos.

\subsubsection{Importância dos setores para Goiás}

O estado de Goiás foi o quarto maior produtor de soja e quinto maior produtor de milho do Brasil na safra 2012/2013 (em torno de 12\% de toda produção nacional para ambas as culturas) (CONAB, 2013a). A Tabela 7 mostra a comparação dos principais estados produtores de grãos do país nos últimos 10 anos e seu crescimento no período.

Tabela 7 - Comparação dos principais estados brasileiros produtores de grãos

\begin{tabular}{|c|c|c|c|c|c|c|c|}
\hline \multicolumn{5}{|c|}{ Milho } & \multicolumn{3}{|c|}{ Soja } \\
\hline Colocação & $2001 / 2002$ & $2012 / 2013$ & $\begin{array}{c}\text { Cresc. } \\
\text { 2001/02- } \\
2012 / 13\end{array}$ & Colocação & $2001 / 2002$ & $2012 / 2013$ & $\begin{array}{c}\text { Cresc. } \\
\text { 2001/02- } \\
\text { 2012/13 }\end{array}$ \\
\hline MT & $2.199,8$ & $19.893,00$ & $804 \%$ & MT & $11.733,0$ & $23.532,80$ & $101 \%$ \\
\hline PR & $9.363,2$ & $17.642,4$ & $88 \%$ & PR & $9.502,3$ & $15.912,4$ & $67 \%$ \\
\hline MS & $1.345,6$ & $7.820,7$ & $681 \%$ & $\mathbf{R S}$ & $5.636,0$ & $12.534,9$ & $122 \%$ \\
\hline MG & $4.787,7$ & $7.452,2$ & $56 \%$ & GO & $5.420,4$ & $8.562,9$ & $58 \%$ \\
\hline GO & $3.394,7$ & $7.125,7$ & $110 \%$ & MS & $3.278,6$ & $5.809,0$ & $77 \%$ \\
\hline RS & $3.905,5$ & $5.383,5$ & $38 \%$ & MG & $1.948,5$ & $3.374,8$ & $73 \%$ \\
\hline SP & $3.941,7$ & $5.200,7$ & $32 \%$ & SP & $1.571,3$ & $2.051,1$ & $31 \%$ \\
\hline $\begin{array}{l}\text { TOTAL } \\
\text { (Brasil) }\end{array}$ & $35.266,8$ & $81.007,2$ & $130 \%$ & $\begin{array}{l}\text { TOTAL } \\
\text { (Brasil) }\end{array}$ & $42.230,0$ & $81.499,4$ & $93 \%$ \\
\hline
\end{tabular}

Fonte: Elaborado pelo autor a partir de CONAB, 2013a.

Na última década, a produção de soja do estado de Goiás cresceu $58 \%$ e a de milho $110 \%$. Números relativamente baixos quando comparados com o crescimento da produção nacional dos produtos, que atingiram 93\% pra a soja e 130\% para o milho (CONAB, 2013a).

As taxas de produtividade das culturas no estado, quando comparadas com a média da produtividade brasileira, como mostra a Tabela 8, apresentam melhores desempenhos, principalmente para o milho, que por apresentar produção mais difusa na área nacional, possui 
níveis de produtividade muito distintos. Porém quando se analisa a evolução da produtividade nos últimos anos, nota-se que, mesmo ainda mantendo níveis altos de produtividade, o aumento do estado ficou aquém da média nacional em ambas as culturas (CONAB, 2013a).

Tabela 8 - Comparação Brasil/Goiás das taxas de produtividade da soja e milho.

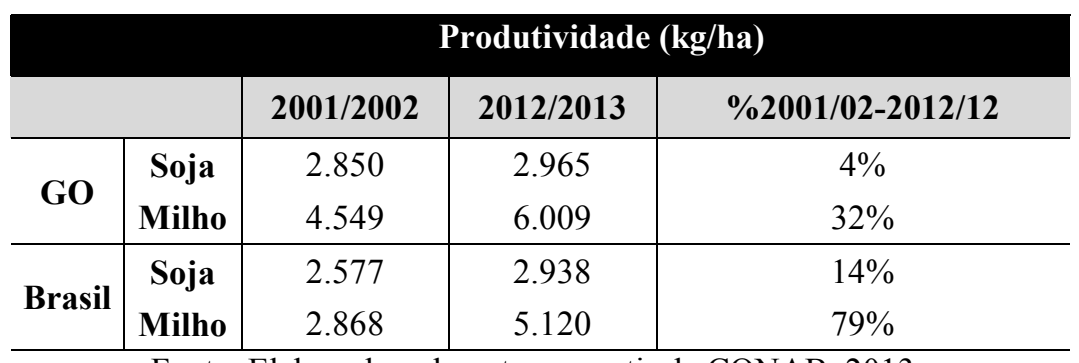

Fonte: Elaborado pelo autor, a partir de CONAB, 2013a

Com os níveis de produtividade mostrados na tabela acima, o estado de Goiás posiciona-se como o sétimo mais produtivo para a soja e o terceiro mais produtivo para o milho (CONAB, 2013a).

Goiás é um estado muito dependente da produção de soja. Cerca de $70 \%$ dos seus municípios possuem áreas plantadas com o produto, porém no sul do estado estão quatro das cinco principais cidades produtoras (Rio Verde, Jataí, Chapadão do Céu e Montividiu). Da mesma maneira que para a soja, o milho é cultivado em quase todas as cidades do estado, porém as cinco maiores produtoras são Jataí, Rio Verde, Cristalina, Chapadão do Céu e Montividiu, nesta ordem (BRASIL, 2007).

O estado também tem representatividade nas exportações nacionais dos produtos, tendo sido responsável por $9 \%$ das exportações nacionais de soja e 16\% das de milho ano de 2012. O principal destino das exportações de soja em grãos foi a China, importando $83 \%$ do total, o que mostra uma alta dependência de apenas um país, diferentemente do que o que ocorre para o milho, que possui destinos de exportações mais diversificados, sendo seus principais importadores Coréia do Sul (18\%), Taiwan (16\%), Irã (13\%) e Japão (12\%) (BRASIL, 2013a).

Com relação às exportações de soja, $67 \%$ do valor exportado por Goiás foi oriundo da soja em grãos (BRASIL, 2013a). Como a Tabela 9 abaixo demonstra, a soja em grãos e o farelo de soja são os produtos deste complexo com menor valor agregado, indicando que o estado precisa buscar aumentar suas exportações de processados como o óleo de soja na busca de maior retorno das suas exportações. 
Tabela 9 - Exportações do complexo soja de Goiás no ano de 2012.

\begin{tabular}{c|c|c|c}
\hline & US\$ & KG & US\$ $/ \mathbf{k g}$ \\
\hline Farelo de Soja & 688.613 .858 & 1.498 .323 .545 & 0,46 \\
Óleo de Soja & 58.421 .469 & 45.413 .969 & 1,29 \\
Grãos de Soja & 1.540 .365 .350 & 2.920 .012 .144 & 0,53 \\
\hline \multicolumn{3}{|c}{ Fonte: Elaborado pelo autor, a partir de BRASIL, 2013a }
\end{tabular}

Apesar dos dados acima, a capacidade de processamento de soja do estado cresceu cerca de 130\% nos últimos oito anos (2006 a 2013), e atualmente Goiás possui 12\% de toda capacidade brasileira. Quanto às suas capacidades de refino e envase, o estado responde por 15\% da capacidade nacional (ABIOVE, 2013).

\subsubsection{Análise dos principais problemas (soja e milho) e posicionamento estratégico das cadeias}

A partir das análises realizadas para o estado e das entrevistas com especialistas, foram identificados os principais problemas presentes nas cadeias de soja e milho de Goiás. Esses problemas, presentes no Quadro 14 fornecem os direcionamentos para a determinação dos objetivos e ações estratégicas do estado.

Quadro 14 - Principais problemas encontrados na cadeia de soja e milho do estado de Goiás.

- Assim como em todos os mercados de commodities, a alta liquidez do produto e ausência de diferenciação diminui a autonomia dos produtores na precificação, deixando a competitividade baseada apenas nos custos de produção.

- São muito pequenos os esforços na busca de diferenciação do produto.

- A distância dos portos aumenta os custos logísticos do estado.

- O estado possui estradas estaduais e municipais em condições precárias, o que prejudica a logística e aumenta o custo de produção dos produtos.

- A Argentina possui vantagens competitivas devido ao seu solo, que requer menor quantidade de fertilizantes, ampla utilização de Organismos Geneticamente Modificados e ao grande processamento interno dos produtos.

- Barreiras de exportação prejudicam a comercialização externa de produtos industrializados.

- Baixo poder de barganha do pequeno e médio produtor na compra de insumos e venda de produtos para a indústria processadora, que é concentrada.

- Poder de barganha das indústrias de transformação reduzido frente às processadoras e tradings.

- Grande poder de barganha das cadeias de aves e suínos, que possuem contratos de integração.

- Altos preços praticados podem viabilizar a entrada de agentes menos competitivos na 


\begin{tabular}{|l|}
\hline cadeia. \\
\hline - O aumento de preços das terras do Centro-Oeste, as novas variedades presentes no \\
mercado e algumas vantagens logísticas estão aumentando a produção competitiva de \\
soja e milho em estados como Piauí, Maranhão e Tocantins.
\end{tabular}
Fonte: Elaborado pelo autor.

A partir dos problemas encontrados no estado, foram determinados os direcionamentos e posicionamento estratégicos para as cadeias. Este posicionamento almejado irá servir de guia para os macro objetivos da cadeia, uma vez que se referem à maneira que a cadeia goiana quer ser enxergada no ano de 2020.

Para a cadeia da soja, o estado deve buscar um aumento do valor agregado nas suas exportações e a redução dos seus custos de produção, atentando-se para a manutenção ou aumento da qualidade em todos os aspectos.

Já para a cadeia do milho, os aspectos que devem ser considerados são o aumento dos volumes de produção e o fortalecimento do seu papel no mercado interno, impulsionado pelo crescimento da produção animal na região em que o estado se localiza. 


\subsubsection{Missão, visão, objetivos e ações estratégicas para o setor no estado (soja e milho)}

\subsubsection{Missão e visão das cadeias}

\section{SOJA}

\section{Missão}

Produzir soja e seus derivados, buscando atender às necessidades de consumo no Brasil e no mundo, respeitando os princípios da sustentabilidade e trabalhando de maneira coordenada para promover o desenvolvimento de Goiás.

\section{Visão}

Ser um centro de excelência na produção e aproveitamento de soja no Brasil, referência no uso de tecnologia, na qualidade e competitividade de seus produtos, promovendo o desenvolvimento do estado e de toda a cadeia.

\section{MILHO}

\section{Missão}

Produzir milho e seus derivados, contribuindo com as demais cadeias produtivas do agronegócio brasileiro no desafio de suprir, de maneira sustentável, as necessidades de consumo da sociedade, por meio do trabalho coordenado de toda a cadeia.

\section{Visão}

Ser o maior produtor de milho do Brasil, produzindo com tecnologia, qualidade, sustentabilidade e competitividade, promovendo o adensamento da cadeia produtiva e maior agregação de valor para o desenvolvimento do Estado.

\subsubsection{Objetivos e ações estratégicas}

De acordo com os problemas identificados e os posicionamentos estratégicos almejados, os objetivos e ações estratégicas propostas para as cadeias de milho e soja do estado de Goiás foram divididos em oito dimensões: Produção, produtos, pesquisa e inovação; Comunicação; Distribuição, logística e exportações; Capacitação e recursos humanos; 
Coordenação e adequação ao ambiente institucional; Sustentabilidade; Micro e pequenas empresas; e Fortalecimento dos elos fracos e inexistentes. No Quadro 15, são organizadas essas dimensões e seus respectivos objetivos e ações estratégicas. 
Quadro 15 - Planos vetores estratégicos, objetivos e ações estratégicas propostas para as cadeias de milho e soja do estado de Goiás.

\begin{tabular}{|c|c|c|}
\hline Planos Vetores Estratégicos & Objetivos & Ações Estratégicas \\
\hline $\begin{array}{l}\text { 1. Produção, produtos, } \\
\text { pesquisa e inovação }\end{array}$ & $\begin{array}{l}\text { - } \text { Aumentar a produção de soja e milho no estado. } \\
\text { - } \quad \text { Fortalecer as indústrias processadoras } \\
\text { pumentar o volume de investimentos em } \\
\text { pesquisas e desenvolvimento. }\end{array}$ & $\begin{array}{l}\text { - Expandir as áreas cultivadas com soja e milho no estado, ocupando } \\
\text { principalmente área de pastagens degradadas. } \\
\text { - Integrar instituições de ensino e pesquisa estaduais públicas e privadas a } \\
\text { fim de aumentar o aporte de pesquisa e inovação. }\end{array}$ \\
\hline 2. Comunicação & 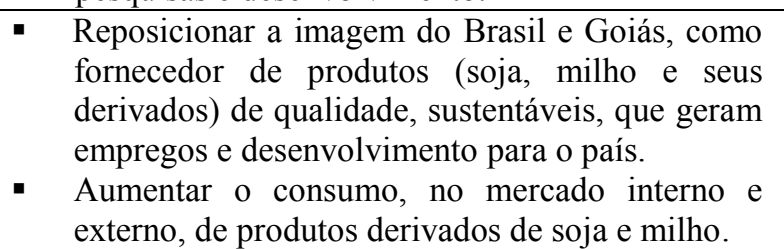 & $\begin{array}{l}\text { - Articular junto ao governo federal um amplo plano de comunicação sobre os } \\
\text { benefícios nutricionais da soja e do milho, tanto no mercado interno quanto } \\
\text { no mercado externo, visando aumentar a demanda por produtos derivados } \\
\text { de soja e milho. } \\
\text { - Quantificar e mapear a cadeia e divulgar os benefícios gerados para a } \\
\text { sociedade. }\end{array}$ \\
\hline $\begin{array}{l}\text { 3. Distribuição, logística e } \\
\text { exportações }\end{array}$ & 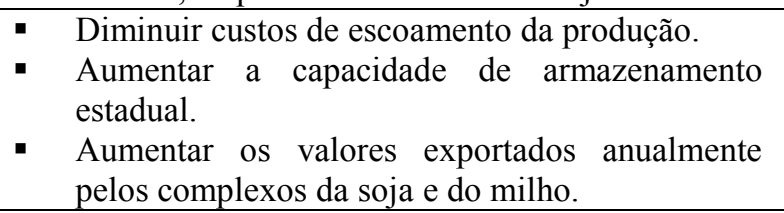 & $\begin{array}{l}\text { - Articular maiores investimentos para alternativas de escoamento da } \\
\text { produção, por meio da utilização de multimodais. } \\
\text { - } \quad \text { Realizar missões comerciais em mercados com alto potencial. } \\
\text { - Criar um pacote de incentivos para a exportação às exportações de produtos } \\
\text { processados de soja e milho. }\end{array}$ \\
\hline $\begin{array}{l}\text { 4. Capacitação/Recursos } \\
\text { Humanos }\end{array}$ & $\begin{array}{l}\text { - Capacitar e qualificar os recursos humanos } \\
\text { utilizados nos diversos elos da cadeia, ampliando } \\
\text { a disponibilidade e a qualidade da mão de obra. } \\
\text { - Reduzir a rotatividade dos trabalhadores. }\end{array}$ & $\begin{array}{l}\text { - Estimular e criar cursos de especialização com objetivo de formar mão de } \\
\text { obra técnica e gerencial especializada na cadeia de grãos. } \\
\text { - Reforçar parcerias com SENAI e SENAR para a oferta de cursos voltados } \\
\text { para o setor. }\end{array}$ \\
\hline $\begin{array}{l}\text { 5. Coordenação e adequação } \\
\text { ao ambiente institucional }\end{array}$ & $\begin{array}{l}\text { Elevar o nível de coordenação da cadeia de grãos } \\
\text { goiana, transformando-a em referência no Brasil } \\
\text { e no mundo. } \\
\text { - Atuar para a redução das alíquotas dos impostos } \\
\text { de exportação dos produtos industrializados. }\end{array}$ & $\begin{array}{l}\text { - Definir um grupo de gestão responsável pela coordenação de um sistema de } \\
\text { governança da cadeia produtiva da soja/milho. } \\
\text { - Auxiliar na elaboração de projetos de investimentos visando maior } \\
\text { adequação técnica às normas. }\end{array}$ \\
\hline 6. Sustentabilidade & $\begin{array}{l}\text { - Difundir a adoção de práticas agrícolas } \\
\text { sustentáveis, bem como a adoção de práticas } \\
\text { sustentáveis nas indústrias. }\end{array}$ & $\begin{array}{l}\text { - Desenvolver e promover um padrão (princípios e critérios) para a } \\
\text { produção responsável de soja e milho. } \\
\text { - Fomentar o desenvolvimento de tecnologias sustentáveis de produção. }\end{array}$ \\
\hline 7. Micro e pequenas empresas & $\begin{array}{l}\text { Fortalecer os micro e pequenos empresários } \\
\text { presentes nas cadeias de grãos no estado. }\end{array}$ & $\begin{array}{l}\text { - Fortalecer as micros, pequenas e médias indústrias já existentes no estado, } \\
\text { dando total apoio e ajuda às mesmas. } \\
\text { - Capacitar em gestão as pequenas e médias propriedades e industrias. }\end{array}$ \\
\hline $\begin{array}{l}\text { 8. Fortalecimento dos elos } \\
\text { fracos e inexistentes }\end{array}$ & $\begin{array}{l}\text { - Fortalecer as indústrias produtoras de insumos } \\
\text { do Estado e estimular a instalação de indústrias } \\
\text { de insumos não existentes no estado }\end{array}$ & $\begin{array}{l}\text { - Articular o incentivo ao aumento do mercado atacadista de fertilizantes. } \\
\text { - Fortalecer e estimular a setor de serviços para agroindústrias de grãos no } \\
\text { estado. }\end{array}$ \\
\hline
\end{tabular}

Fonte: Elaborado pelo autor 


\subsection{Setor sucroenergético}

Para uma análise detalhada do setor sucroenergético, devem ser levados em conta seus dois principais produtos: açúcar e etanol, porém, além dos dados desses, a situação da produção canavieira também deve ser investigada, permitindo que os direcionamentos sejam ainda mais claros.

\subsubsection{Introdução à cadeia}

A cultura da cana-de-açúcar teve o início de seu crescimento por volta do ano de 1985 , quando a frota de carros a álcool começou a aumentar. Naquele ano, a produção brasileira era de cerca de 200 milhões de toneladas, e daí em diante seu crescimento foi tão grande que atingiu em 2011 em torno de 560 milhões de toneladas. O crescimento da produção foi principalmente no estado de São Paulo, que possuía clima e solo favoráveis. Em 1985, o estado era responsável por 55\% de toda produção brasileira de cana (ÚNICA, 2011).

Com o aumento da demanda por etanol, açúcar e novos produtos derivados da cana, suas fronteiras de produção foram expandidas. Na safra 2011/2012, São Paulo continuou na primeira colocação, respondendo por $54 \%$ da produção nacional de cana-de-açúcar, porém seu crescimento em dez anos foi de 105\%, enquanto estados como Goiás, Mato Grosso do Sul e Minas Gerais registraram crescimentos de, respectivamente, 527\%, 419\% e 369\%, impulsionados pelos preços mais baixos de terras, por suas áreas ainda não ocupadas e pelos incentivos governamentais ao desenvolvimento do setor (ÚNICA, 2013).

\section{Açúcar}

Por ser de grande importância para a indústria alimentícia, o açúcar é uma das commodities mais transacionadas no mercado internacional. Nota-se que em regiões tropicais o açúcar é produzido a partir da cana-de-açúcar, porém, nas regiões temperadas a matéria prima mais utilizada é a beterraba.

A produção mundial de açúcar cresceu $28 \%$ em dez anos, atingindo o valor de 171,9 milhões de toneladas. O Brasil é o principal país produtor da commodity $(36,1$ milhões de toneladas, ou $21 \%$ da produção mundial, em 2012), seguido pela Índia (28,6 milhões de toneladas) e União Europeia (18,3 milhões de toneladas) (UNITED STATES, 2013). 
O consumo de açúcar é influenciado pelas mudanças nas estruturas populacionais e na renda. Dessa maneira, países em crescimento como a China (52\%), Indonésia (51\%) e Índia (21\%) são os mercados que mais cresceram, contabilizando crescimentos de $52 \%, 51 \%$ e $21 \%$, respectivamente, nos últimos dez anos (UNITED STATES 2013).

Além de ser o maior produtor, o Brasil é um grande exportador. Na safra 2011/2012 suas exportações representaram $42,6 \%$ das exportações mundiais, no entanto, este valor foi menor que dos anos anteriores $(48,1 \%$ e $52,9 \%)$ devido a uma quebra de safra e emergência de novos players no mercado (BRASIL, 2013a).

Os principais destinos das exportações de açúcar brasileiras são os países em pleno crescimento, nos quais o consumo de alimentos está crescendo com a população e a redistribuição de renda. No ano de 2012, o Brasil exportou açúcar para 134 diferentes países, somando um valor de US\$12,8 bilhões, sendo seus principais destinos China, com 8,4\%; Emirados Árabes e Argélia, com 6\%; e Rússia, com 5,7\% (BRASIL, 2013a).

Na safra 2011/2012, São Paulo foi o estado que mais produziu açúcar, tendo produzido 21,7 milhões de toneladas, correspondentes a $59 \%$ da produção nacional. Minas Gerais, Paraná, Alagoas e Goiás seguiram o estado nesta ordem, sendo responsáveis por, respectivamente, 9\%, 8\%, 7\% e 5\% da produção nacional (ÚNICA, 2013).

Do total de açúcar produzido e consumido no País, $40 \%$ é destinado ao varejo e $60 \%$ à indústria para a produção de alimentos industrializados (NEVES; CONEJERO, 2007).

\section{Etanol}

A demanda do etanol como combustível ganhou destaque no cenário mundial na virada do século XXI, devido às crescentes preocupações relacionadas ao aquecimento global e ao encarecimento do petróleo. Desta maneira, entre 2001 e 2008 a produção mundial de etanol passou de 33,9 bilhões de litros para 65,6 bilhões. Já nos anos seguintes, o crescimento foi um pouco mais tímido, por causa da crise financeira de 2008. No ano de 2011, foram produzidos 84,6 bilhões de litros, valor 3\% menor que em 2010 (RFA, 2012).

Até o ano de 2005, o Brasil liderava o ranking dos maiores produtores mundiais de etanol, porém após essa data, os EUA passaram a frente. Brasil e EUA produziram juntos $87 \%$ de todo etanol comercializado no mundo, tendo produzido respectivamente 21,1 e 52,6 bilhões de litros em 2011 (RFA, 2012).

Uma característica importante deste mercado é que ele é altamente subsidiado e protegido da competição externa, refletindo então a demanda interna de cada país e possuindo poucas transações entre países. Apesar deste fato, muitos países não têm capacidade para 
atender sua demanda, impulsionada pela imposição de leis que determinam adição de etanol na gasolina, resultando no aumento das exportações, desta maneira, as exportações brasileiras do produto passaram de 2,4 bilhões de litros em 2001 para 5,13 bilhões em 2008 (BRASIL, 2013a). Internamente, com a criação da tecnologia flex-fuel no ano de 2003, a demanda por etanol aumentou significantemente, impulsionando também a sua produção, que teve um salto de $150 \%$ em dez anos (CONAB, 2013a).

Assim como para o açúcar, São Paulo figura como o maior estado produtor de etanol, tendo respondido por 51\% de toda produção nacional na safra 2011/2012 (11,59 bilhões de litros). O estado de Goiás ocupa o segundo lugar na produção (2,67 bilhões de litros), seguido por Minas Gerais, Mato Grosso do Sul e Minas Gerais (ÚNICA, 2013).As projeções para o etanol indicam que na safra 2021/2022, a produção será de cerca de 60 bilhões de litros. Para tanto, o País terá que trabalhar intensamente no setor (BRASIL, 2012a).

\subsubsection{Importância do setor para Goiás}

O estado de Goiás teve grande destaque na expansão da atividade da cana-de-açúcar nos últimos anos. Sua produção agrícola cresceu 527\% em dez anos, passando a responder por $8 \%$ da produção de cana nacional (ÚNICA, 2013).

A expansão no estado ocorreu na região Sul/Sudoeste, mais especificamente nas regiões de Meia Ponte, Quirinópolis, Sudoeste de Goiás e vale do Rio dos Bois. No ano de 2012, o estado possuía 732.870 ha de área plantada com cana, representando 8,6\% da área plantada na região centro-sul e 7,5\% de toda área plantada do País (ÚNICA, 2013).

O estado é o maior em áreas aptas ainda não cultivadas com cana, onde dos seus 12,6 milhões de hectares aptos, 7,8 milhões são ocupados com pastagens e 4,8 com culturas agrícolas, o que representa uma grande oportunidade para o setor (CONAB, 2013a).

A produção canavieira é localizada normalmente próxima às usinas, possibilitando os grandes volumes envolvidos na logística de colheita e carregamento. Das 130 unidades industriais associadas à União das Indústrias de Cana-de-Açúcar (ÚNICA) presentes no país, sete delas estão localizadas no estado de Goiás, o que representa 5\% do total (ÚNICA, 2014).

Com relação às associações de produtores, das 34 associações associadas à Organização dos Plantadores de Cana da Região Centro-sul do Brasil (ORPLANA), apenas três são pertencentes ao estado de Goiás (ORPLANA, 2014). 


\section{Açúcar}

Apesar de o setor sucroenergético do estado estar mais voltado a produção de etanol (aproximadamente $60 \%$ da produção), a produção de açúcar cresceu consideravelmente nas últimas safras passando de 397 mil toneladas na safra 2000/2001 para 1,7 milhões de toneladas na safra 2011/2012 (CONAB, 2013a).

As longas distâncias do Estado até os portos exportadores aumentam muito os custos das exportações de açúcar do estado de Goiás, fazendo com que o estado exporte poucas quantidades. $\mathrm{O}$ estado participou com cerca de $4 \%$ das exportações totais do país no ano e 2012. Na safra 2000/2001 foram exportados apenas 9\% da sua produção, já na safra 2011/2012 esse valor aumentou para 33,4\% impulsionado pela valorização recorde do produto no mercado internacional (BRASIL, 2013a).

O mercado interno de açúcar é bem explorado pelas usinas goianas, que utilizam sua localização central como facilitador logístico para a entrega do produto em indústrias de alimentos e bebidas.

\section{Etanol}

Como já dito, o setor sucroenergético de Goiás é mais voltado para a produção de etanol. O estado foi o que mais cresceu em produção nos últimos anos, contabilizando crescimento de 741\% (ÚNICA, 2013).

O estado de Goiás se consolida como um Estado superavitário no mercado de etanol independentemente da demanda, uma vez que conseguiria abastecer sua frota de veículos leves mesmo que ela fosse inteiramente abastecida com etanol. Dessa maneira, o estado está pronto para se fortalecer, de maneira competitiva, nos principais mercados consumidores dentro e fora do País.

\subsubsection{Análise dos principais problemas}

Os principais problemas identificados no setor sucroenergético do estado de Goiás, por meio das análises realizadas e entrevistas com especialistas, estão descritos no Quadro 16 a seguir e servem de direcionamento para as ações a serem tomadas no estado. 
Quadro 16 - Principais problemas encontrados na cadeia sucroenergética do estado de Goiás.

- Estados como Minas Gerais e Mato Grosso do Sul competem com Goiás na atração de novos investimentos uma vez que possuem áreas aptas para a produção canavieira. Além do Mato Grosso do Sul possuir uma área de alta aptidão seis vezes maior que a de Goiás.

- O setor sofre grande concorrência de terras com outras culturas (soja e milho). A valorização dessas culturas tem elevado o preço da terra.

- A elevação dos preços das terras em Goiás pode direcionar investimentos para Mato Grosso, Tocantins e Maranhão.

- Apesar da grande integração vertical do setor, muitas usinas estão buscando terceirizar a produção canavieira, diminuindo capital imobilizado em terras. Produtores independentes conseguem custos de produção menores que usinas.

- As usinas possuem grande poder de barganha frente aos produtores devido aos volumes de compra realizados. Da mesma maneira, os fornecedores de insumos também tem maior poder sobre os preços que os produtores.

- Compradores de açúcar e álcool possuem grande poder de barganha apesar dos preços serem cotados em bolsas de mercadoria. Os produtores são tomadores de preço.

- Uma ameaça para a produção brasileira são os baixos custos de produção e grande disponibilidades de terras de países da África, Ásia e América Latina, atraindo investimentos.

- Os custos de produção no Brasil estão aumentando, reduzindo a sua competitividade.

- O etanol é a segunda opção dos motoristas de automóveis flex.

- O número de fornecedores de cana do estado ainda é pequeno.

- O associativismo entre fornecedores ainda é baixo, assim como a coordenação entre usinas e fornecedores.

- O estado não possui conselho para estruturação de um sistema de remuneração próprio, utilizando o CONSECANA de São Paulo que não é tão adequado devido as diferenças nos mixes de produção dos estados.

- São necessários investimentos em modernização das unidades industriais principalmente para os sistemas de cogeração.

- Muitas usinas de Goiás que são unidades industriais de empresas de São Paulo continuam realizando compras de seus fornecedores tradicionais, deixando de realizar compras locais.

- Necessidade de novas variedades de cana mais adaptadas ao estado.

- Grandes fornecedores de equipamentos industriais são localizados em São Paulo (Sertãozinho e Piracicaba).

- Ausência de um programa de prevenção e controle de pragas em cana na Agrodefesa.

- Necessidade de maior disseminação das melhores práticas de cultivo e manejo.

- Problemas na construção da ferrovia Norte-Sul.

- Necessidade de aumentar a capacidade da hidrovia Tietê-Paraná com novas eclusas e barcaças para o transporte de etanol.

- Existe um gargalo de mão de obra tanto operacional quanto gerencial. A competição por mão de obra com outros setores também é grande.

- A falta de estrutura de algumas cidades de Goiás inviabiliza a vinda de profissionais de outras localidades.

- Necessidade do aumento da diferença de encargos entre gasolina e etanol para garantir a competitividade do produto.

- Goiás possui maiores restrições do que São Paulo e Minas Gerais quanto a reservas legais.

- Difícil e burocrático acesso a linhas de financiamento.

Fonte: Elaborado pelo autor. 
A partir dos problemas levantados, foram determinados os direcionamentos estratégicos para o setor no estado, que, por meio das ações estratégicas buscam atingir o posicionamento estratégico almejado para o estado no ano de 2020. O posicionamento ira direcionar os macro objetivos.

O posicionamento estratégico para o setor sucroenergético do estado de Goiás deve ser guiado pelo aumento da sua competitividade no mercado para atração de novos investimentos. Para tanto, o aumento da produtividade agrícola deve ser focado, bem como a redução dos custos de produção agrícolas.

\subsubsection{Missão, visão, objetivos e ações estratégicas para o setor no estado}

\subsubsection{Missão e Visão para o setor}

\section{Missão}

Fornecer alimentos e energia limpa e renovável para a sociedade, contribuindo diretamente para o desenvolvimento sustentável de Goiás, por meio do trabalho conjunto e fortalecimento de toda a cadeia.

\section{Visão}

Ser uma cadeia forte e unida e transformar o Estado de Goiás no mais competitivo e produtivo do setor sucroenergético brasileiro, tornando-o o principal destino dos investimentos do setor.

\subsubsection{Objetivos e ações estratégicas}

De acordo com os problemas identificados e os posicionamentos estratégicos almejados, os objetivos e ações estratégicas propostas para o setor sucroenergético do estado de Goiás foram divididos em oito dimensões: Produção, produtos, pesquisa e inovação; Comunicação; Distribuição, logística e exportações; Capacitação e recursos humanos; 
Coordenação e adequação ao ambiente institucional; Sustentabilidade; Micro e pequenas empresas; e Fortalecimento dos elos fracos e inexistentes. No Quadro 17 são organizadas essas dimensões e seus respectivos objetivos e ações estratégicas. 
Quadro 17 - Planos vetores estratégicos, objetivos e ações estratégicas propostas para o setor sucroenergético do estado de Goiás.

\begin{tabular}{|c|c|c|}
\hline Planos Vetores Estratégicos & Objetivos & Ações Estratégicas \\
\hline $\begin{array}{l}\text { 1. Produção, produtos, } \\
\text { pesquisa e inovação }\end{array}$ & $\begin{array}{l}\text { - Aumentar a produção de cana-de-açúcar e a } \\
\text { - } \\
\text { Agriciegncia industrial } \\
\text { desenvolvendo conjuntamente mercados de } \\
\text { nicho }\end{array}$ & $\begin{array}{l}\text { - Expandir áreas de cana, sobretudo em pastagens degradadas. } \\
\text { - } \quad \text { Fesenvolver alternativas, como o sorgo sacarino, para reduzir o tempo de entressafra. } \\
\text { eficiência no campo e na indústria. }\end{array}$ \\
\hline 2. Comunicação & $\begin{array}{l}\text { - Melhorar a imagem da cadeia aproximando-a do } \\
\text { consumidor. } \\
\text { Atrair novos investimentos para o estado (novos } \\
\text { projetos). } \\
\text { - Aumentar a comunicação entre as empresas, } \\
\text { coordenação e benchmarking. }\end{array}$ & $\begin{array}{l}\text { - Realizar missões empresariais e acordos comerciais para estimular as exportações dos } \\
\text { diversos produtos do setor. } \\
\text { - } \quad \text { Quantificar e divulgar resultados da cadeia produtiva no estado. } \\
\text { - } \quad \text { Implenibilizar informações técnicas e institucionais do Estado e dos municípios. }\end{array}$ \\
\hline $\begin{array}{l}\text { 3. Distribuição, logística e } \\
\text { exportações }\end{array}$ & $\begin{array}{l}\text { - Reduzir os custos de escoamento da produção } \\
\text { ampliando a venda para outros estados. } \\
\text { Aumentar a eficiência da logística interna, em } \\
\text { usinas e fornecedores. }\end{array}$ & $\begin{array}{l}\text { - Reduzir a dependência do modal rodoviário, ampliando o ferroviário, o hidroviário e o } \\
\text { dutoviário. } \\
\text { - } \quad \text { Desburocratizar exportações. } \\
\text { - Investir no aperfeiçoamento das tecnologias e dos processos industriais e agrícolas. }\end{array}$ \\
\hline $\begin{array}{l}\text { 4. Capacitação/Recursos } \\
\text { Humanos }\end{array}$ & $\begin{array}{l}\text { - Capacitar e qualificar a mão de obra nos níveis } \\
\text { técnico-operacionais e gerenciais. } \\
\text { - } \quad \text { Reduzir a rotatividade dos trabalhadores. } \\
\text { - } \\
\text { Adequar trabalhadores a legislação trabalhista. }\end{array}$ & $\begin{array}{l}\text { - Reforçar parcerias com SENAI e SENAR para a oferta de cursos voltados ao setor. } \\
\text { - Reduzir a rotatividade da mão de obra. } \\
\text { Implantar associações e sindicatos que regulamentam e defendam a classe de } \\
\text { trabalhadores. }\end{array}$ \\
\hline $\begin{array}{l}\text { 5. Coordenação e adequação } \\
\text { ao ambiente institucional }\end{array}$ & $\begin{array}{l}\text { - Aumentar o fornecimento de incentivos ao setor } \\
\text { - } \text { Aumentar a coordenação eficiente reduzindo } \\
\text { custos de transação na cadeia. }\end{array}$ & $\begin{array}{l}\text { - } \quad \text { Unificar sobre o etanol, o ICMS nacional. } \\
\text { - } \quad \text { Aumentar a quantidade de etanol nas misturas com gasolina. } \\
\text { - } \quad \text { Disponibilizar linhas de financiamento. } \\
\end{array}$ \\
\hline 6. Sustentabilidade & $\begin{array}{l}\text { - Expandir a área plantada em áreas de pastagem } \\
\text { degradada e adequar as propriedades ao Novo } \\
\text { Código Florestal. } \\
\text { Melhorar o balanço ambiental dos processos } \\
\text { agrícolas e industriais. }\end{array}$ & $\begin{array}{l}\text { - Desenvolver programas estaduais de adequação e certificação ambiental. } \\
\text { - } \text { Ampliar estímulos para projetos em áreas de pastagem degradadas. } \\
\text { - } \quad \text { Promover maior integração entre as usinas e a comunidade. } \\
\text { - Desenvolver processos que visam a melhoria do balanço ambiental na atividade. }\end{array}$ \\
\hline 7. Micro e pequenas empresas & $\begin{array}{l}\text { - } \quad \text { Ampliar as compras locais. } \\
\text { Fortalecer os pequenos e médios fornecedores } \\
\text { independentes de cana. }\end{array}$ & $\begin{array}{l}\text { - Capacitar em gestão os pequenos e médios fornecedores fomentando seu } \\
\text { associativismo. } \\
\text { - Incentivas compras e vendas conjuntas de pequenos e médios estabelecimentos. } \\
\text { - Articular formas de melhoria de incentivos para micro, pequenos e médios } \\
\text { estabelecimentos. }\end{array}$ \\
\hline $\begin{array}{l}\text { 8. Fortalecimento dos elos } \\
\text { fracos e inexistentes }\end{array}$ & $\begin{array}{l}\text { - Criar um polo de indústrias fornecedoras de } \\
\text { produtos, serviços e tecnologias para o setor } \\
\text { sucroenergético. }\end{array}$ & $\begin{array}{l}\text { - Formar uma parceria com o Sifaeg e o CEISE Br para promover o desenvolvimento da } \\
\text { indústria sucroenergética e seus fornecedores. } \\
\text { - Criar programas de incentivos e divulgar oportunidades de investimentos. }\end{array}$ \\
\hline
\end{tabular}




\section{CONTRIBUIÇÕES DOS AGENTES ENVOLVIDOS DIRETAMENTE NA} ELABORAÇÃO DO PLANO ESTRATÉGICO PARA O NOVO MÉTODO

O questionário disponível no anexo $\mathrm{A}$ foi submetido a dois entrevistados que participaram ativamente da elaboração do plano estratégico para as cadeias produtivas do estado de Goiás, sendo um o coordenador do projeto em Goiás e presidente do Conselho Temático de Agronegócios da FIEG na ocasião e a assessora técnica da FIEG/COTEC.

A maioria das contribuições dos entrevistados foram incorporadas ao novo método proposto, fazendo parte dos resultados da presente pesquisa ou utilizadas como validação do método proposto. Outras sugestões foram pontuadas no capítulo de "sugestões de estudos futuros".

No geral, os entrevistados consideraram o plano e sua sequência de execução coerentes com o que se propunha, sendo que atingiu seu objetivo final de propor sugestões de ações estratégicas aos agentes produtivos, facilitadores e institucionais das cadeias no estado.

Segundo os entrevistados, a elaboração do plano seguindo uma metodologia participativa possibilitou que os conhecimentos e percepções do público local fossem contemplados no trabalho.

A fase de entrevistas inicial, com os 35 interlocutores das cadeias foi realizada por telefone. Segundo os entrevistados, essas entrevistas deveriam ser feitas presencialmente para se ter a garantia de que todos os detalhes e observações fossem capturados. Muitas vezes, em entrevistas por telefone, o entrevistado não está realmente focado e pode responder as perguntas mais rápido e suscintamente para dar sequência às suas atividades do dia-a-dia. Um "pré-workshop" facilitaria o envolvimento e participação dessas pessoas nas entrevistas iniciais.

Além do meio pelo qual as entrevistas são realizadas, outra sugestão nesse aspecto foi com relação ao número e áreas dos entrevistados.

No trabalho foi realizada uma média de sete entrevistas por cadeia, entretanto, essas não contemplaram necessariamente todos os elos das cadeias. Muitos agentes institucionais participaram das entrevistas e a participação dos setores produtivos ficou defasada.

As entrevistas deveriam contemplar todos os elos, sendo que deveria ser entrevistado mais de um agente por elo pois mesmo dentro de cada elo, existem diferenças regionais e de nível de produção dentro do estado. Se pudessem ser realizadas mais entrevistas por elo contemplando todos os elos da cadeia, mais agentes seriam sensibilizados e o sucesso da 
execução posterior do plano poderia ser maior, porém o grau de dificuldade em reunir todas essas pessoas é alto.

Com relação ao workshop para validação dos planos propostos, os entrevistados acreditam que o problema é semelhante ao das entrevistas iniciais. Foi pontuado que os workshops são o "ponto alto" do processo, porque gera um envolvimento muito grande. No caso das cadeias estudadas, as pessoas que participaram dos workshops contribuíram muito, porém a amostra deveria ser mais significativa, os elos de produção e da indústria não estavam plenamente representados.

A sugestão nesse aspecto é a execução de um workshop por elo da cadeia, sendo assegurado que os principais interlocutores estão presentes. A identificação e sensibilização desses interlocutores deve ser responsabilidade da organização institucional facilitadora do plano. Uma restrição presente nesta etapa é o alto orçamento necessário.

Outro aspecto considerado nas entrevistas com os envolvidos na elaboração do plano que também trata do envolvimento dos interlocutores das cadeias foi o desconhecimento por parte dos interlocutores a respeito do que é, ou quais os resultados de um plano de gestão estratégica. Por nunca terem um contato prévio com a construção de um plano estratégico para um setor, os interlocutores não estavam focados para o resultado final do processo, introduzindo, em algumas ocasiões, aspectos secundários ao plano.

Especificamente para o estado de Goiás, onde um primeiro trabalho de gestão estratégica já foi realizado, os entrevistados acreditam que os subsequentes terão mais foco e consequentemente os resultados serão melhores. Em locais em que ainda não existe essa sensibilização, anteriormente à elaboração do plano, os interlocutores participantes devem entender a sequência de ações, ferramentas, propósitos e objetivos de um plano de gestão estratégica para seu maior envolvimento e melhores resultados finais.

Cumpre observar, adicionalmente, que as entrevistas também trouxeram contribuições com relação à entrega final dos planos estratégicos.

Como os agentes dos elos das cadeias são os principais responsáveis por dar sequência à execução dos planos estratégicos, a organização institucional responsável pela elaboração dos planos deve estar muito atenta na forma final dos resultados. Nesse aspecto, são destacados dois pontos: a linguagem da apresentação final e os meios de divulgação do material.

Com relação à linguagem, o texto deve possuir uma escrita de fácil leitura e entendimento. Ademais, foi sugerido uma apresentação mais gráfica do que escrita, com 
desenhos e esquemas tornando mais fácil o entendimento de todo o material e, principalmente, dos próximos passos.

No tocante à divulgação, os responsáveis devem atentar-se para atingir o maior número de pessoas possível, divulgando não apenas por meios impressos, mas também digitalmente. Podem ser realizados eventos de divulgação do material, contudo, é fundamental a presença dos agentes pertencentes a todos os elos da cadeia.

Apesar de a metodologia já ser participativa, os entrevistados acreditam que o sucesso da execução dos planos propostos depende majoritariamente do envolvimento e engajamento dos agentes das cadeias. A organização institucional é responsável, desde a sensibilização até a proposição dos planos estratégicos, porém a execução dos planos é altamente dependente dos agentes, que devem ser envolvidos ao máximo na elaboração dos planos para terem condições e disposição para darem sequência na execução das ações.

Por fim, a execução das ações estratégicas foi questionada e nesse aspecto os entrevistados pontuaram, mais uma vez, que ela está diretamente ligada ao engajamento dos agentes do setor. Apesar de a metodologia utilizada ser participativa, um maior envolvimento dos agentes dos setores traria resultados mais consistentes e aumentaria as chances da execução das ações na sequência.

Uma grande dificuldade que a maioria das cadeias produtivas no país enfrenta atualmente é a execução de ações conjuntas em prol do setor. Cada agente está focado nas soluções dos próprios problemas, não se envolvendo com questões coletivas que dizem respeito ao futuro de seu negócio.

Devido a essa característica das cadeias produtivas brasileiras, deveria ser desenvolvida uma metodologia específica apenas para o acompanhamento da execução das ações. Foi pontuado que a execução de planos estratégicos deve ser uma nova área de conhecimento, fundamentada em aspectos teóricos e práticos. 


\section{O MÉtOdo de GeSTÃo ESTRATÉGICA DE CADEIAS PRODUTIVAS PARA UM RECORTE ESTADUAL}

Após revisão de literatura a respeito dos métodos de planejamento e gestão estratégica existentes, revisão do método GESis proposto por Neves (2008), avaliação dos estudos de caso em que o método GESis adaptado foi aplicado em cinco cadeias produtivas do estado de Goiás e entrevistas com os responsáveis diretos pela execução do plano de Goiás, foi definido o método de Gestão Estratégica de Cadeias Produtivas para um Recorte Estadual, que conta com 13 etapas. Suas etapas são descritas a seguir.

\subsection{ETAPA 1: Sensibilização para execução do plano}

Para a execução de um plano de gestão estratégica de cadeias produtivas de um estado, inicialmente alguma organização que possua interesse direto nos resultados desse plano deve sensibilizar-se e buscar sua execução. Essa etapa é de fundamental importância, visto que essa organização vai agir como facilitadora da execução do plano, indicando possíveis interlocutores, acompanhando e validando as informações geradas pelo plano.

\subsection{ETAPA 2: Sensibilização dos agentes pertencentes à cadeia alvo do estudo}

Para as etapas subsequentes, a participação e engajamento de agentes dos diversos elos da cadeia alvo do estudo é fundamental. Para tanto, o atual método sugere que seja realizada uma reunião inicial de alinhamento, contando com agentes de todos os elos da cadeia em quantidade suficiente e representativa daquele elo no estado.

Nessa reunião, o método utilizado deve ser muito bem explicado, assim como suas etapas subsequentes, ferramentas, análises e, principalmente, o objetivo final de todo o trabalho. 
Uma vez que os agentes estejam alinhados, a elaboração e andamento das fases subsequentes do plano serão facilitados e a execução das ações resultantes do plano terá maior chance de ser concretizada.

\subsection{ETAPA 3: Levantamento e análise do ambiente externo}

Nesta etapa, deve ser realizado um amplo levantamento e detalhamento do ambiente ao qual a cadeia alvo do plano está inserida. Aspectos como situação dos mercados, análise de dados da produção, consumo, comportamento do consumidor, tanto no ambiente nacional quanto no internacional, devem ser muito bem estudados e analisados.

Duas ferramentas que devem ser usadas como 'guia' para o levantamento de tais informações são a PEST e o Modelo de Cinco Forças de Porter. Além de guiar o levantamento das informações, essas duas ferramentas permitem uma melhor visualização dos dados para a tomada de decisões quanto ao presente e futuro da cadeia alvo do plano.

Após execução da ferramenta PEST, em que os aspectos político-regulatórios, econômico-naturais, tecnológicos, sócio demográficos e culturais são levantados, e do modelo de Cinco Forças de Porter, um quadro de consolidação deve ser feito, a fim de organizar as ameaças e oportunidades oriundas do ambiente e externo e já identificar algumas ações estratégicas. A Figura 13, abaixo, exemplifica como pode ser o quadro de consolidação da ferramenta.

AÇÕESE PROJETOS

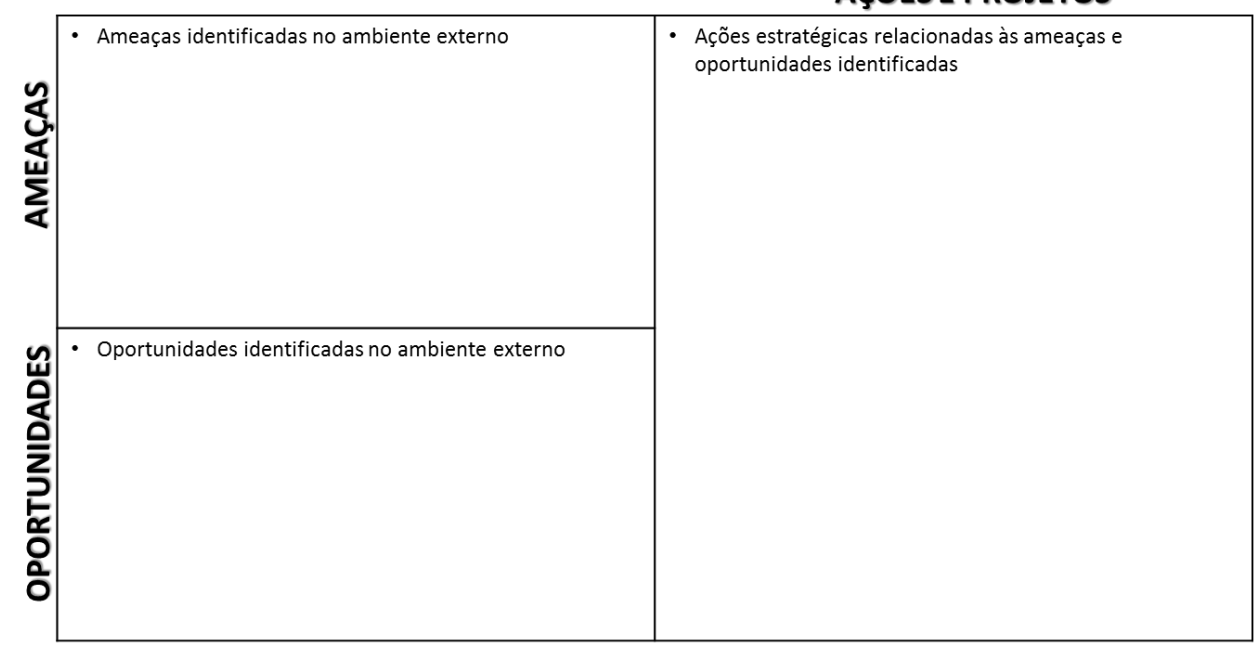

Figura 13 - Quadro de consolidação das ferramentas PEST e Cinco Forças de Porter Fonte: Adaptado de NEVES, 2005 


\subsection{ETAPA 4: Levantamento e análise do ambiente interno}

Da mesma maneira que se avalia o ambiente externo, o ambiente interno da cadeia deve ser analisado. Nesse ponto, vale destacar que a unidade estadual deve ser entendida como "ambiente interno". Alguns dos dados a serem buscados para a análise do ambiente interno da cadeia são:

- capacidade produtiva dividida por elo da cadeia alvo;

- situação de cada elo existente, comparativamente com outros estados ou outros países (produtividade, 'tecnificação', capacidade de expansão, entre outros);

- investigação a respeito de elos que deveriam estar presentes, mas não se encontram no estado;

- principais mercados consumidores;

- situação da mão-de-obra no estado;

- quantidade e qualidade dos sistemas de ensino e preparação técnica do estado;

- situação dos sistemas de assistência técnica presentes no estado;

- gargalos e oportunidades logísticas para o estado;

- concorrentes;

- levantamento e análise separada da situação de pequenos, médios e grandes produtores;

Para a análise do ambiente interno, as ferramentas que auxiliarão na organização das informações são a SWOT e o modelo do Diamante de Porter e, da mesma maneira que para a análise do ambiente externo, um quadro de consolidação deve ser preenchido após essa etapa.

\subsection{ETAPA 5: Situação interna na visão de especialistas e agentes do setor}

A Etapa 5 tem o papel de completar e validar os dados levantados nas etapas 3 e 4, entretanto, agora por meio de dados primários, entrevistas com especialistas e agentes do setor alvo do plano.

Nesta etapa, o papel da organização sensibilizada na etapa 1 fica evidente, pois ela agirá como agente facilitador e elo entre o elaborador do plano e os possíveis entrevistados. 
As entrevistas devem buscar mapear a situação interna da cadeia (lembrando que a unidade estadual deve estar clara) na visão de pessoas que vivem o dia a dia dessa cadeia. Informações levantadas nas etapas anteriores devem ser confirmadas e confrontadas com as fornecidas pelos entrevistados, dando mais força, maior veracidade e consequentemente subsídios mais concretos para a posterior tomada de decisão com relação aos direcionamentos estratégicos da cadeia alvo do plano.

Para o maior aproveitamento dessas entrevistas, elas devem ser realizadas presencialmente e com número significativo de agentes por elo da cadeia alvo do estudo. Sugere-se aqui a realização de um 'pré-workshop' com os agentes que já foram sensibilizados na etapa 2, para facilitar a interação dos entrevistadores com os entrevistados.

\subsection{ETAPA 6: Benchmarking}

Para fornecer ainda mais subsídios para a tomada de decisão quanto ao posicionamento estratégico da cadeia alvo no estado, alguns polos de referência também devem ser estudados.

Devem ser escolhidos dois ou três estados ou países onde a cadeia alvo do plano é muito bem desenvolvida, com os direcionamentos claros e pilares muito bem estabelecidos. A partir de então, alguns aspectos dessas cadeias devem ser analisados para posteriormente serem utilizados como referência para o direcionamento estratégico da cadeia.

- Informações gerais do polo

- Pontos fortes e fracos

- Estratégias utilizadas

- Estratégias que podem ser replicadas para a cadeia alvo

\subsection{ETAPA 7: Determinação do posicionamento estratégico da cadeia}

A partir de todos os dados levantados e analisados nas etapas anteriores e do benchmarking realizado com os polos de referência da cadeia alvo do plano, deve ser determinado o posicionamento estratégico da cadeia para o estado. Aqui, entende-se por 
posicionamento estratégico o local que a cadeia quer ocupar no futuro. Duas dimensões estratégicas devem ser determinadas e a cadeia deve se posicionar frente a essas duas dimensões. A Figura 14 exemplifica como esse processo pode ser feito. Os polos analisados no benchmark devem ser tomados como referência.

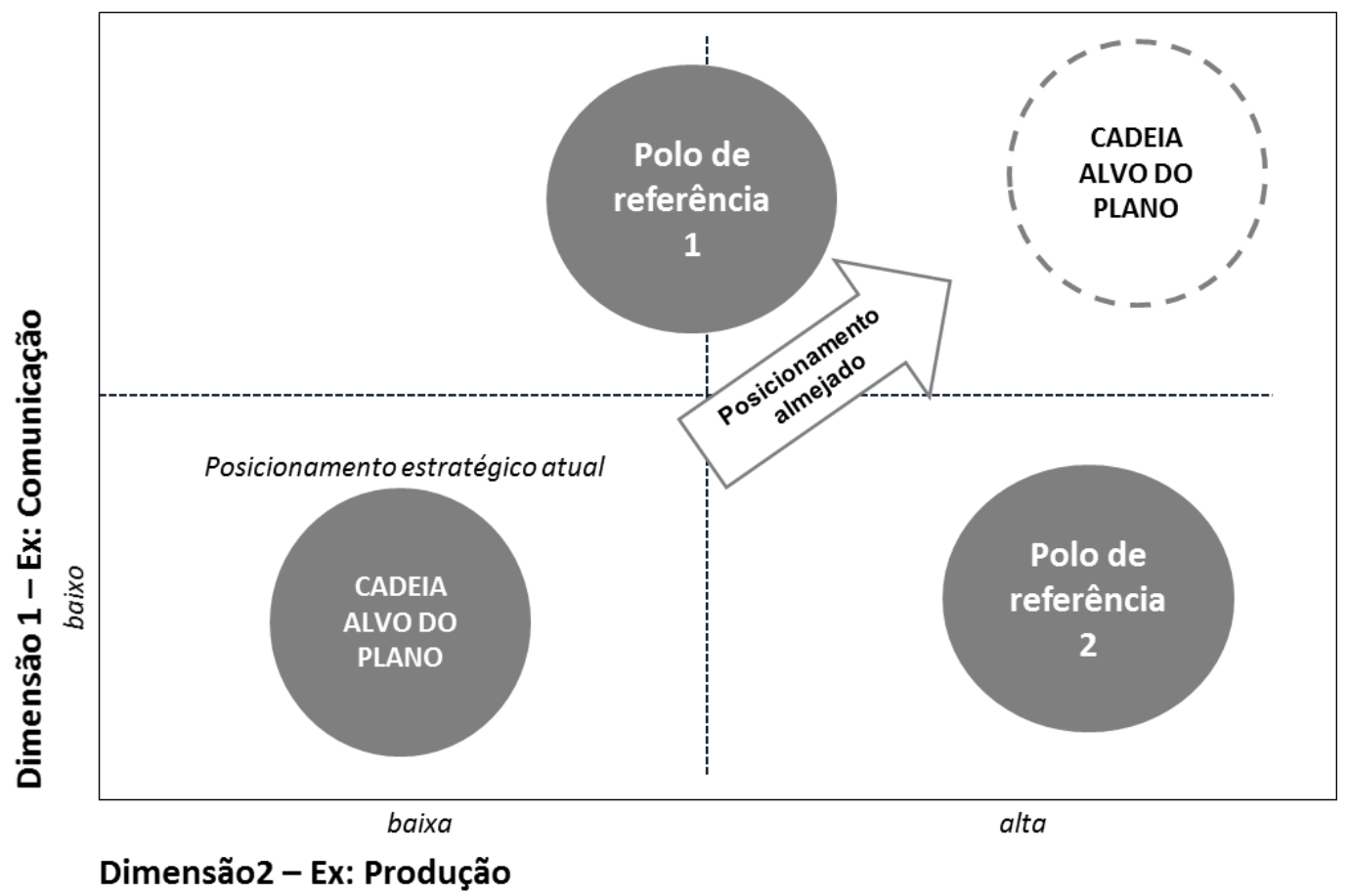

Figura 14 - Matriz de posicionamento estratégico Fonte: Adaptado de NEVES, 2005

\subsection{ETAPA 8: Proposição de missão e visão para a cadeia}

Uma vez analisados os ambientes internos e externos os quais a cadeia se insere, realizado o benchmarking e determinado o posicionamento estratégico da organização, sua missão e visão devem ser estabelecidas.

A missão deve representar a razão da existência da organização, contemplando todos os elementos de sua direção estratégica. No caso do presente estudo, a organização pode ser entendida como a cadeia produtiva do estado. Para tanto, ela deve contemplar o propósito básico da cadeia e os valores que devem ser agregados à sua imagem.

A visão, por sua vez, deve indicar o que a organização pretende ser no futuro, fornecendo uma visão clara de como se espera que o setor desenvolva-se e qual papel ele irá exercer no futuro (HARRISON, 2005). 


\subsection{ETAPA 9: Identificação dos vetores estratégicos a serem trabalhados e proposição de objetivos e ações para cada um}

Nesta etapa, devem ser identificados quais os vetores a serem trabalhados no plano. Exemplos de vetores são Produção e Produto; Pesquisa e Desenvolvimento; Comunicação; Distribuição e Logística; Recursos Humanos, entre outros.

O Método de Gestão Estratégica de Cadeias Produtivas para um Recorde Estadual não busca deixar pré-definidos os vetores estratégicos a serem trabalhados, porque, uma vez que cada cadeia apresenta uma situação particular e cada estado possui uma situação única no contexto que está inserido, é mais adequado que o planejador identifique quais os vetores ideais a serem trabalhados em cada contexto.

É importante ter uma definição clara de quais vetores mais impactarão com maior e menor intensidade para o estado atingir o seu posicionamento estratégico almejado. Uma vez definidos os vetores, devem ser então estabelecidos os objetivos e ações dentro de cada um, bem como seus indicadores de desempenho, que serão utilizados posteriormente na fase de controle do plano.

\subsection{ETAPA 10: Workshop com especialistas e agentes da cadeia alvo no estado para validação do plano de gestão estratégica para o estado}

De maneira semelhante à encontrada na etapa 5, esta etapa tem como principal objetivo validar o posicionamento estratégico, missão, visão, objetivos e ações estratégicas. Aqui, são sugeridos workshops com especialistas e agentes da cadeia, em que todo material deve ser apresentado e submetido a discussões para validação. Essa etapa é considerada igualmente importante no plano, pois considera a visão dos que estão diretamente envolvidos na cadeia, dando mais consistência ao plano.

É importante ressaltar que, para uma visão mais próxima da realidade e melhor aproveitamento de todo o trabalho de planejamento, deve ser realizado um workshop por elo relevante da cadeia e este deve conter agentes suficientes que representem a realidade do elo no estado todo. 


\subsection{ETAPA 11: Apresentação do plano e determinação de responsáveis e prazos para sua execução}

Após validação e sugestão dos especialistas, o plano deve ser finalizado e entregue para a organização de interesse. A partir de então, inicia-se a fase de colocá-lo em ação.

Para tanto, devem ser determinados responsáveis e prazos para execução de cada ação estratégica. Uma maneira de organizar a execução do plano é por meio da classificação de suas ações em ações de curto, médio e longo prazo.

O orçamento de cada ação estratégica e mapeamento das competências básicas necessárias para sua realização também devem ser determinados.

Esta etapa é muito dependente dos esforços da organização que se propôs executar o plano, todavia, reveste-se de importância que o planejador acompanhe o processo, fornecendo apoio e possíveis direcionamentos para a organização.

\subsection{ETAPA 12: Divulgação do plano estratégico}

Nesta etapa, deve ficar claro que a organização setorial sensibilizada, responsável pela elaboração do plano estratégico, forneça subsídios para que cada agente da cadeia, relacionado diretamente com uma ou outra área, dê andamento à execução das ações estratégicas resultantes do plano.

Para tanto, é fundamental que o plano final seja divulgado a toda a cadeia, de modo que esta tenha conhecimento e capacidade para se envolver ativamente nas etapas subsequentes.

Uma divulgação efetiva utiliza tantos meios de comunicação quantos o público alvo necessita para ser atingido. 


\subsection{ETAPA 13: Controle}

Uma vez implementado, o plano deve ser submetido a sistemas de controle constantes. Os indicadores de desempenho estabelecidos na Etapa 8 devem ser muito bem trabalhados, desenvolvidos pelos responsáveis e revisados com periodicidade, para que o plano não se torne obsoleto ou inadequado para a situação atual da cadeia no estado.

A Figura 15 ilustra como o método de Gestão Estratégica para Cadeias Produtivas em um Recorte Estadual deve ser conduzido, mostrando as principais entradas de cada etapa e respectiva saída para sequência do plano.

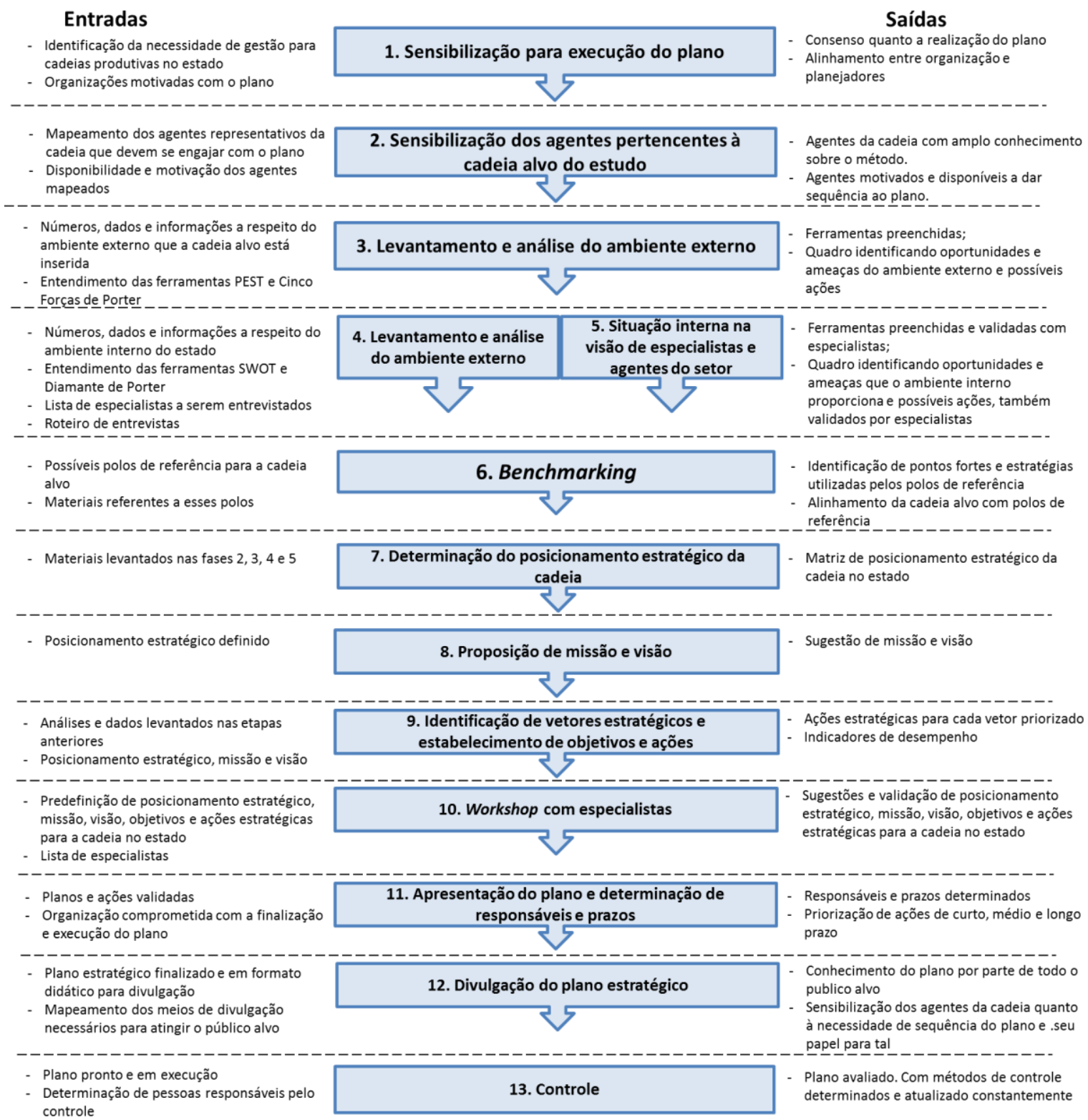

Figura 15 - Plano de Gestão Estratégica de Cadeias Produtivas para um Recorte Estadual Fonte:Elaborado pelo autor 


\section{CONSIDERAÇÕES FINAIS, IMPLICAÇÕES GERENCIAIS, LIMITAÇÕES E SUGESTÕES DE ESTUDOS FUTUROS}

\section{CONSIDERAÇÕES FINAIS E IMPLICAÇÕES GERENCIAIS}

Esta dissertação buscou atingir seu objetivo de fornecer subsídios para a gestão estratégica de cadeias produtivas delimitadas a estados por meio do entendimento de métodos de planejamento e gestão estratégica alternativos e da proposição de um método específico para tal.

O objetivo final da dissertação foi cumprido, com a proposição do Método de Gestão Estratégica de Cadeias Produtivas para um Recorte Estadual, que conta com 13 etapas sendo elas: (1) Sensibilização para execução do plano; (2) Sensibilização dos agentes pertencentes à cadeia alvo do estudo; (3) Levantamento e análise do ambiente externo; (4) Levantamento e análise do ambiente interno; (5) Situação interna na visão de especialistas e agentes do setor; (6) Benchmarking; (7) Determinação do posicionamento estratégico da cadeia; (8) Proposição de missão e visão para a cadeia; (9) Identificação dos vetores estratégicos a serem trabalhados e proposição de objetivos e ações para cada um; (10) Workshop com especialistas e agentes da cadeia alvo no estado para validação do plano de Gestão Estratégica para o estado; (11) Apresentação do plano e determinação de responsáveis e prazos para sua execução; (12) Divulgação do plano estratégico; (13) Controle.

Os objetivos específicos da dissertação também foram alcançados uma vez que foram identificadas e estudadas outras contribuições de diversos autores sobre o tema de gestão estratégica; o método GESis proposto por Neves (2008) e sua adaptação foram descritos e avaliados de forma comparativa; foram estudadas as particularidades dos estados; e a aplicação do método GESis adaptado em cinco cadeias produtivas do estado de Goiás foi descrita e avaliada.

A dissertação contribui com a teoria de Gestão Estratégica, que já conta com diversos métodos propostos para diversas áreas, no entanto, não possuía um específico para cadeias produtivas delimitadas espacialmente a unidades da federação.

Com relação ao método, ele pode ser considerado um método simples, de aplicação fácil e prática, porém altamente dependente da sensibilização e engajamento dos agentes envolvidos. Por não possuir os vetores estratégicos já estabelecidos, tal método é mais facilmente adaptável às diversas realidades encontradas. 
Nos estudos de caso avaliados, foram necessários 8 vetores estratégicos por cadeia para contemplar todas as ações estratégicas necessárias. Nesse caso os vetores estratégicos foram:

(1) Produção, produtos, pesquisa e inovação;

(2) Comunicação;

(3) Distribuição, logística e exportações;

(4) Capacitação e recursos humanos;

(5) Coordenação e adequação ao ambiente institucional;

(6) Sustentabilidade;

(7) Micro e pequenas empresas;

(8) Fortalecimento dos elos fracos e inexistentes.

A vivência prática da autora na aplicação do método nas cinco cadeias produtivas do estado de Goiás permite que seja tirada uma conclusão que impacta diretamente no sucesso do método: os agentes das cadeias produtivas brasileiras ainda estão muito aquém do ideal no tocante da coordenação setorial, tanto vertical quanto horizontal.

Ficou evidente que ações conjuntas são dificultadas pela cultura do produtor brasileiro, que não enxerga sua classe como uma unidade, e sim apenas o seu negócio.

Uma solução que minimizaria esse fato, é a criação de comitês executores, sendo um por vetor estratégico, que possuem um objetivo comum e se comunicam com os demais na busca de possíveis soluções conjuntas complementares, porém, para tanto, é necessário um forte e centralizado agente coordenador.

Outra conclusão evidente das aplicações foi que o nível de produtividade das cadeias produtivas do estado de Goiás, no geral, estão aquém daqueles alcançados por outros estados, existindo nesse ponto uma grande oportunidade de melhoria do estado. É importante que os agentes produtivos do estado tenham essa consciência para poderem direcionar esforços. Se o estado não estiver ciente que a produtividade ainda pode ser muito melhorada, novos investimentos podem ser feitos em áreas que não trarão tantos resultados.

Espera-se que o método proposto seja de grande utilidade para organizações públicas e privadas que buscam uma maior organização do setor agrícola de seu estado. Contando com as ferramentas e procedimentos apresentados, espera-se que os líderes estaduais tenham sucesso no planejamento de seus setores, e uma vez que cada estado do País esteja 
organizado, os líderes possam identificar necessidades comuns e trabalhar aspectos interestaduais.

Para tanto, deve ocorrer ampla sensibilização e percepção da necessidade de um trabalho como este para o setor do agronegócio brasileiro. Somente dessa maneira a iniciativa de coordenação surgirá.

Apesar do trabalho gerar um método sólido e de ampla aplicabilidade, durante a sua execução algumas limitações foram encontradas, e dessas limitações decorrem possíveis sugestões de pesquisas futuras.

\section{LIMITAÇÕES}

- O método proposto foi baseado na aplicação de um método de gestão estratégica em cinco cadeias produtivas de um mesmo estado, e com agentes facilitadores comuns, ou seja, o modelo conceitual teórico ainda poderá sofrer diversas limitações quando da sua aplicação em outros cenários, com outros agentes envolvidos. Apesar de ser um método sólido e claro, a influência dos executores está diretamente ligada aos seus resultados finais.

- Como já pontuado, as pessoas envolvidas tanto na elaboração do método quanto na execução das ações resultantes de sua aplicação são outra limitação do trabalho que influencia diretamente o seu sucesso. Para resultados satisfatórios todos os envolvidos devem estar altamente comprometidos e com foco no resultado final. Nos estudos de caso descritos neste trabalho, a execução das ações resultantes da aplicação do método foi comprometida devido a falta de agentes coordenados para tal.

- Com relação à análise dos estudos de caso, pode-se dizer que elas ficaram restritas à fase de entrega dos planos estratégicos. Apesar das entrevistas finais, com os gestores, contemplarem perguntas relativas à execução dos planos estratégicos e ações propostas, elas não fazem parte do método proposto.

- A próxima limitação encontrada no trabalho diz respeito a natureza da análise dos dados envolvidos no mesmo. O presente trabalho é de natureza estritamente qualitativa. $\mathrm{O}$ desenvolvimento de uma análise quantitativa, com testes de hipótese e conclusões comprovadas estatisticamente daria maior força ao método.

- A última limitação encontrada nesse trabalho é que o método final proposto não foi validado por nenhum gestor de cadeias produtivas.

Apesar do método final proposto ser próximo daquele que foi aplicado nas cinco cadeias produtivas do estado de Goiás, algumas mudanças foram realizadas baseadas nas entrevistas finais. Devido a essa proximidade, no presente trabalho, optou-se por priorizar a 
avaliação do método aplicado nos estudos de caso e captar sugestões de melhoria a serem incorporadas no método final.

\section{SUGESTÕES DE ESTUDOS FUTUROS}

- Pode-se dizer que se o método for aplicado em outros estados, com outras realidades, novas conclusões podem surgir, que não estão previstas nesse trabalho, sendo esta a primeira sugestão de estudos futuros.

A aplicação do método proposto em novos estados, com realidades diferentes das encontradas em Goiás irá testar a sua eficiência e complementá-lo, sendo que nesse aspecto, as diferenças encontradas entre estados poderão ser destacadas no método, facilitando e melhorando a sua aplicabilidade.

A partir da aplicação do método em diferentes estados da federação, a possibilidade da realização de ações conjuntas interestadualmente pode emergir, entrando no método como mais um vetor estratégico ou como ação específica e destacada dentro de um de seus vetores.

- Outra sugestão de estudo futuro é a aplicação do método em outros países, que seguindo o raciocínio descrito acima, também auxiliará no melhor entendimento e clareza de suas ferramentas deixando-o cada vez mais completo e com maior utilidade.

- Um novo método complementar ao proposto com foco na execução das ações estratégicas proposta é mais uma sugestão de estudo futuro decorrente deste trabalho. O novo método deveria, além de dar claros subsídios e ferramentas para o acompanhamento, execução e avaliação da aplicação das ações estratégicas, fazer uma ligação coerente entre todas as etapas e ter um foco específico na coordenação das pessoas envolvidas.

- A última sugestão de estudo futuro pertinente é a estruturação de um método quantitativo baseado no método qualitativo resultante desse trabalho. 


\section{Referências bibliográficas}

ABIOVE - Associação Brasileira das Indústrias de Óleos Vegetais. Estatísticas do complexo soja. 2013. Disponível em: $<$ http://www.abiove.org.br/site/index.php?page=estatistica\&area $=$ NC0yLTE $=>$. Acesso em: 11 jan. 2013.

ABUD, G.C.; LIMA, R.R. Conseleite: O que é? Scot Consultoria, Bebedouro, 27 nov. 2009. Disponível em: $<\mathrm{http}: / / \mathrm{www}$. scotconsultoria.com.br/noticias/artigos/22772/conseleite:-o-quee> Acesso em: 25 fev. 2014.

AFONSO, R. A. Proposição de um método de planejamento e gestão estratégica de clusters. 2012. 188 f. Dissertação (Mestrado). Departamento de Administração da Faculdade de Economia, Administração e Contabilidade da Universidade de São Paulo. Ribeirão Preto, 2012.

ANSOFF, H. I. Corporate strategy: an analytic approach to business police for growth and expansion. Nova York: McGraw-Hill, 1965. Revisado 1987.

ANSOFF, H.I. Strategic issue management. Strategic management Journal. v.1 p.131-148, 1980.

APPELBAUM, E. P. S. H. 2003. The case for case studies in management research. Management Research News, v.26, n.5, p.60-71.

ASSOCIAÇÃO NACIONAL DOS CONFINADORES - ASSOCON. Levantamento da ASSOCON sobre o sistema de produção em confinamento no Brasil. 2012. Disponível em: $\quad<$ http://www.assocon.com.br/wordpress/wp-content/uploads/2012/12/Levantamentosobre-Confinamento-ASSOCON-2012.pdf> . Acesso em: 14 de fev. 2013.

BALDONI, R. Financial risk management: journey or destination? Directorship, v. 26, n.6, p.13-20, 2001.

BARBOSA, E. R.; BRONDANI, G. Planejamento estratégico organizacional. Revista Eletrônica de Contabilidade, Santa Maria, v.1, n.2, p.107-123, 2004.

BARNEY, M.B. Firm resources and sustained competitive advantage. Journal of Management, v. 17, p. 99-120, 1991.

BEINHOCKER, E. D. The origin of wealth: the radical remaking of economics and what it means for business and society. Boston: Harvard Business School Press, 2007.

BOEHLJE, M.; ROUCAN-KANE, M.; BRÖRING, S. Future Agribusiness Challenges: Strategic Uncertainty, Innovation and Structural Change. International Food and Agribusiness Management Review, v. 14, n. 5, 2011.

BONOMA, T. V. Case research in marketing: opportunities, problems and a process. Journal of Marketing Research. v.22, n. 2, p.199-208, 1985.

BORJA, J.; CASTELLS, M. Local and Global: management of cities in the information age. London: Earthscan Publications, 1997. 277p. 
BRASIL. Instituto Brasileiro de Geografia e Estatística - IBGE. Censo Agropecuário 2006: Resultados preliminares. Rio de Janeiro. 2007, 146p.

BRASIL. Relação anual de informações sociais - RAIS. Brasília. 2010. Disponível em: $<$ http://www.rais.gov.br/RAIS_SITIO/tabelas.asp>. Acesso em: 19 nov 2013.

BRASIL. Instituto Brasileiro de Geografia e Estatística - IBGE. Indicadores IBGE: Estatística da Produção Pecuária 2010. 2011 Disponível em: < http://www.ibge.gov.br/home/estatistica/indicadores/agropecuaria/producaoagropecuaria/abat e-leite-couro-ovos_201004_publ_completa.pdf>. Acesso em: 15 fev. 2014.

BRASIL. Ministério da Agricultura, Pecuária e Abastecimento - Assessoria de Gestão Estratégica. Brasil projeções do agronegócio 2011/2012 a 2021/2022. Brasília. 2012a. Disponível em: $<$ http://www.agricultura.gov.br/arq_editor/file/Ministerio/gestao/projecao/Projecoes $\% 20 \mathrm{do} \%$ 20Agronegocio\%20Brasil\%202011-20012\%20a\%202021-2022\%20(2)(1).pdf $>$. Acesso em: 17 mai. 2013.

BRASIL. Ministério da Agricultura, Pecuária e Abastecimento - Secretaria da Política Agrícola. Plano Agrícola e Pecuário 2012/2013. Brasília. 2012b. Disponível em: $<$ http://www.agricultura.gov.br/politica-agricola/plano-agricola-pecuario-2012-2013>.

Acesso em: 23 mai. 2013.

BRASIL. Ministério do Desenvolvimento, Indústria e Comércio Exterior. Secretaria de Comércio Exterior. Bases Estatísticas. 2013a. Disponível em: <www.aliceweb.desenvolvimento.gov.br>. Acesso em: 22 dez. de 2013.

BRASIL. Instituto Brasileiro de Geografia e Estatística - IBGE. Indicadores IBGE: Estatística da Produção Pecuária 2012/2013. 2013b Disponível em: $<$ http://www.ibge.gov.br/home/estatistica/indicadores/agropecuaria/producaoagropecuaria/ab ate-leite-couro-ovos_201303_publ_completa.pdf $>$. Acesso em 12 de jan. de 2014.

BRASIL. Instituto Brasileiro de Geografia e Estatística - IBGE. Produção da Pecuária Municipal 2012. Rio de Janeiro. 2013c. Disponível em: $<\mathrm{ftp}$ //ftp.ibge.gov.br/Producao_Pecuaria/Producao_da_Pecuaria_Municipal/2012/ppm2012.p df $>$. Acesso em: 23 jan. 2014.

BRASIL. Ministério do Desenvolvimento, Indústria e Comércio Exterior. Secretaria de Comércio Exterior. Bases Estatísticas. 2014. Disponível em: $<$ www.aliceweb.desenvolvimento.gov.br>. Acesso em: 28 abr. de 2014.

BRASSINGTON, F.; PETTITT, S. Principles of marketing. 3a ed. Harlow, Essex: Financial Times Prentice Hall, 2003.

BRYSON, J.M.; ALSTON, F.K. Creating your strategic plan: a workbook for public and nonprofit organizations. 3a ed. São Francisco: John Willey \& Sons, 2011. 288p.

CAMPOMAR, M.C. Do uso de "estudo de caso" em pesquisas para dissertações e teses em administração. Revista da Administração, v.26, n.3, p.95-97, 1991.

CARVALHO, F. Práticas de planejamento estratégico e sua aplicação em organizações de terceiro setor. 2004. Dissertação (mestrado). Departamento de Administração da Faculdade de Economia, Administração e Contabilidade da Universidade de São Paulo. São Paulo, 2004. 
CEPEA. Centro de Estudos Avançados de Economia Aplicada - ESALQ - USP. Preços ao produtor: valores nominais do leite. Piracicaba, 2013. Disponível em $<$ http://cepea.esalq.usp.br/leite/?page=155>. Acesso em: 25 fev 2014.

COMAN, A.; RONEN, B. Focused SWOT: diagnosing critical strengths and weaknesses. International Journal of Production Research, v. 47, n. 20, p. 5677-5689, 2009.

CONAB. Companhia Nacional de Abastecimento. Séries Históricas. 2013a Disponível em: $<$ http://www.conab.gov.br/conteudos.php?a=1252\&t=2>. Acesso em 18 dez. 2013.

CONAB. Companhia Nacional de Abastecimento. Custo de produção estimado: leite. 2013b. Disponível em $<$ http://www.conab.gov.br/conteudos.php?a $=1285 \& \mathrm{t}=2>$. Acesso em: 25 fev 2014.

CONEJERO, M.A. Planejamento e gestão estratégica de associações de interesse privado do agronegócio: uma contribuição empírica. 2011. 309 f. Tese (Doutorado). Departamento de Administração da Faculdade de Economia, Administração e Contabilidade da Universidade de São Paulo. São Paulo, 2011.

COOPER, D.; SCHINDLER, P. S. Métodos de pesquisa em administração. $7^{\mathrm{a}}$ ed. Porto Alegre: Bookman, 2003. 640p.

DAVIS, J.H.; GOLDBERG, R.A. A concept of agribusiness. Boston: Division of Research, Graduate School of Business Administration, Harvard University. 1957. 136p.DETRE, Jet al. Scorecarding and Heat Mapping: Tools and Concepts for Assessing Strategic Uncertainty. International Food and Agribusiness Management Review. v. 9, n.1, p.1-22, 2006.

DRUCKER, P. F. Introdução à administração. $3^{\mathrm{a}}$ ed. São Paulo: Pioneira, 1998.

DRUCKER, P. F. Desafios gerenciais para o século XXI. São Paulo: Cengage Learning Editores, 2006. 168p.

EISENHARDT, K. Building theories from case study research. Academy of Management Review, v.14, n.4, p. 532-560, 1989.

FAEG. Federação da Agricultura e Pecuária de Goiás. Diagnóstico da Cadeia Produtiva do Leite de Goiás. Goiânia. 2009. Disponível em: < http://www.milkpoint.com.br/pdf/DiagnosticodaProducaode\%20LeitedoEstadodeGoias.pdf $>$. Acesso em: 24 jan 2014.

FARIAS FILHO, M.C.; FERREIRA, A.O.; SOUZA, F.M. A contribuição do planejamento estratégico para o alcance de objetivos institucionais: estudo de caso em uma universidade particular no estado do Pará. V Encontro de Estudos em Estratégia -ANPAD . Porto Alegre, 2011.

FERREIRA, A.B. de H. Novo Dicionário Aurélio da Língua Portuguesa. $2^{\mathrm{a}}$ edição, $12^{\mathrm{a}}$ impressão. Rio de Janeiro: Nova Fronteira, 1986.Editora Positivo,2004.

GASQUES, J.G.; BASTOS, E. T.; VALDES, C.; BACCHI, M.R.P. Produtividade da agricultura brasileira e os efeitos de algumas políticas públicas. Revista de Política Agrícola. v.21, n.3, p 83-92, 2012.

GEREFFI, G.; HUMPHREY, J.; STURGEON, T. The governance of global value chains. Review of International Political Economy. v.12, n.1, p.78-104, 2005. 
GIL, A. C. Como elaborar projetos de pesquisa. 4. ed. São Paulo: Atlas, 2006.

GIL, A. C. Métodos e técnicas de pesquisa social. 5.ed. São Paulo: Atlas, 1999.

GOLDBERG , R. A. Agribusiness coordination: a systems approach to the wheat, soybean, and Florida orange economies. Harvard University/Graduate School of Business and Administration/Division of Research, 1968.

HAIR, J.J.; MONEY, A.; SAMOUEL, P. Fundamentos de métodos de pesquisa em administração. Porto Alegre: Bookman, 2005.

HARRISON, J.S. Administração estratégica de recursos e relacionamentos. Bookman: Porto Alegre, 2005.430p.

HAX, A. C.; MAJLUF, N. S. The strategy concept and process: a pragmatic approach. 2a ed. New Jersey: Prentice Hall, 1996.

HOPKINGS, T. K.; WALLERSTEIN, I. Commodity chains in the World - Economy prior to 1800. Review (Fernand Braudel Center), v.10, n.1, p. 157-170, 1986.

INFORMA ECONOMICS. FNP. Anualpec 2012. São Paulo: INFORMA ECONOMICS, 2012.

INFORMA ECONOMICS. FNP. Agrianual 2013. São Paulo: INFORMA ECONOMICS, 2013.

KENAN, P. Strategic management for agribusiness. Bulletin of University of Agricultural Sciences and Veterinary Medicine Cluj-Napoca. Horticulture v. 63. n. 1-2, p. 248-253. 2006.

LAMBIN, J. J. Market-driven management: strategic and operational marketing. 3a ed. United Kingdom: Palgrave Macmillan, 2012. 590p.

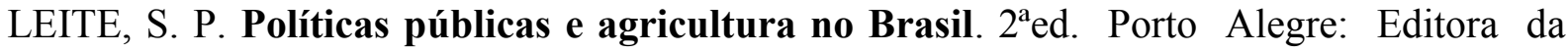
UFRGS, 2009. 252 p.

LOASBY, B.J. Choice, complexity and ignorance: an enquiry into economic theory and the pactice of decision-making. Cambridge [Eng.]. Nova York: Cambridge University Press, 1976. 242p.

LOPES, R. A cidade intencional: o planejamento estratégico de cidades. Rio de Janeiro: Mauad, 1998. 184p.

LUCHIARI FILHO, A.. Produção de carne bovina no Brasil qualidade, quantidade ou ambas? In: II SIMBOI - Simpósio sobre Desafios e Novas Tecnologias na Bovinocultura de Corte, 2006, Brasília.

MACHADO FILHO, C.A.P..; MARINO, M.K.; CONEJERO, M.A. Strategic management in agribusiness cooperatives. ANAIS-IV International Conference on Agri-food Chain and Networks Economics and Management. Universidade de São Paulo. PENSA/USP, FUNDACE. 2003.

MALHOTRA, N. K. Pesquisa de marketing: uma orientação aplicada. $4^{\text {a }}$ ed. Porto Alegre: Bookman, 2006. 720p. 
MATTAR, F. N. Pesquisa de marketing - edição compacta. Atlas, 1993.

MCNEILly, M. R. Sun Tzu and The Art of Business: Six Strategic Principles for Managers. Oxford University Press. 1996. 272p.

MINTZBERG, H. The rise and fall of strategic planning. Londres: Prentice Hall, 1994. $458 \mathrm{p}$.

MINTZBERG, H.; AHLSTRAND, B., LAMPEL, J. Safári da estratégia: um roteiro pela selva do planejamento estratégico. $2^{\mathrm{a}}$ ed. Porto Alegre: Bookman, 2010. 392p.

MORVAN, Y. "Filière de Production" in Fondaments d'economie industrielle. Economica. p.199-231, 1985.

NEVES, J. L. Pesquisa qualitativa: características, usos e possibilidades. Caderno de Pesquisas em Administração, v.1, n.3, p. 103-113, 2 sem. São Paulo, 1996.

NEVES, M. F. Planejamento e gestão estratégica de marketing. São Paulo: Atlas, 2005. $232 \mathrm{p}$.

NEVES, M. F. Método para planejamento e gestão estratégica de sistemas agroindustriais (GESis).Revista da Administração, v. 43, n.4, p. 331-343. São Paulo, 2008.

NEVES, M. F.; CONEJERO, M. A. Cenário econômico da produção de alimentos, fibras e bioenergia. In: NEVES, M. F. (org.). Agronegócios e desenvolvimento sustentável: uma agenda para a liderança mundial na produção de alimentos e bioenergia. São Paulo: Atlas, 2007.

NEVES, M. F; MACHADO FILHO, C.P.; CARVALHO, D.T.; CASTRO, L.T. Redes agroalimentares \& marketing da carne bovina em 2010. In: IV Congresso Brasileiro das Raças Zebuínas. Uberaba, 2000.

NEVES, M. F. Estratégias para a carne bovina no Brasil. São Paulo: Atlas, 2012. 237p.

NIEME, E.H.; NIEME, J.; NIEME, J. Global food production under alternative scenarios. International Food and Agribusiness Management Review. v.13, n.4, p.117-135. 2010.

NUTT, P. C.; BACKOFF, R. W. A strategic management process for public anda third sector organizations. Journal of the American Planning Association, v.53, n. 1, p. 44-57, 1987.

OMTA, S.W.F.; TRIENEKENS, J.H.; BEERS, G. Chain and network science: a research framework. Journal on Chain and Network Science, v.1, n.1, p.1-6, 2001.

ORGANIZAÇÃO DAS NAÇÕES UNIDAS PARA ALIMENTAÇÃO E AGRICULTURA. OCDE (FAO). Agricultural Outlook 2012-2021. 2012 Disponível em: $<$ http://stats.oecd.org/Index.aspx?DataSetCode=HIGH_AGLINK_2012>. Acesso em: 06 de fev. 2013. Genebra, 2013.

ORGANIZAÇÃO MUNDIAL DO COMÉRCIO (OMC). WTO Annual Report. Genebra, 2010 .

ORPLANA - Organização de Plantadores de Cana da Região Centro-Sul do Brasil. Associações. 2014. Disponível em:

$<\mathrm{http}$ ://www.orplana.com.br/novosite/associacoes.php?p=5>. Acesso em: 22 jan 2014. 
O'SHANASSY, T. Sustainable competitive advantage or temporary competitive advantage: improving understanding of an important strategy construct. Journal of Strategy and Management, v.1, n.2, p.168-180, 2008.

OTTO, I. M. C; NEVES, M. F; PINTO, M. J. A. Construindo juntos o futuro do agronegócio em Goiás: cadeia produtiva de carnes e couro bovino. Goiânia: FIEG, 2012. 180 p.

PORAY, M.; GRAY, A.; BOEHLJE, M.; PRECKEL, P. Evaluation of alternative coordination system between producers and packers in the pork value chain. International Food and Agribusiness Management Review, v.6, n.2, p.65-85, 2003.

PORTER, M. E. Competitive strategy: techniques for analyzing industries and competitors. New York: Free Press, 1980.

PORTER, M. E. Estratégia competitiva: técnicas para análise de indústrias e da concorrência. 7. ed. Rio de Janeiro: Campus, 1997.

PORTER, M. E. Competitive advantage: creating and sustaining superior performance. New York: Free Press, 1998.

RFA - Renewable Fuel Association. Industry Statistics. 2012. Disponível em: $<$ www.ethanolrfa.org/pages/statistics>. Acesso em 15 dez 2012.

RICHARDSON, R. J. Pesquisa social: métodos e técnicas. 3ª ed. São Paulo: Atlas, 2008.

SAAB, M.S.; NEVES, M.F.; CLÁUDIO, L.D.C. O desafio da coordenação e seus impactos sobre a competitividade de cadeias e sistemas agroindustriais. Revista Brasileira de Zootecnia, v.38, p.412-422, 2009.

SECRETARIA DE ESTADO DE GESTÃO E PLANEJAMENTO - SEGPLAN. Competências SEAGRI. 2013. Disponível em: <http://www.segplan.go.gov.br/post/ver/108975/seagri-2>. Acesso em: 29 abr. 2013.

SEGPLAN - SECRETARIA DE ESTADO DE GESTÃO E PLANEJAMENTO. Exportações goianas crescem 67\% em março. 2012. Disponível em: $<$ http://www.seplan.go.gov.br/sepin/down\%5Ccomex201203.pdf $>$. Acesso em: 14 de fev. 2013.

SELLTIZ, C. Métodos de pesquisa nas relações sociais. Tradução Dante Moreira Leite. 2. ed. São Paulo: Herder, 1967. 687p. Título Original: Research Methods in Social Relations.

SENESI, S. Proceso de cambio y dinamización del conglomerado de oleaginosos de Uruguay - Lineamentos estratégicos. Uruguay, 2013.

SILVA, R.T.P.; BARCELOS, J.J.; FALCHETTI, S.A. Estudo da aplicação do planejamento para a atividade pecuária bovina de cria, recria e engorda: um estudo de caso - fazenda Santa Maria da Amazônia. Simpósio da Administração da Produção, Logística e Operações Internacionais. Anais, 2010.

TOLEDO, L.A.; CAMPOMAR, M.C.; TOLEDO, G.L. Planejamento de marketing e confecção do plano de marketing: uma análise crítica. O\&S. Organizações \& Sociedade. v.13, n.37, p 1-20, 2006. 
TRIENEKENS, J. H.2011. Agricultural value chain in developing countries: a framework for analisys. International Food and Agribusiness Management Review, v. 14 n. 2, 2011.

ÚNICA - União da Indústria de Cana de Açúcar. UNICADATA. 2013. Disponível em: $<$ www.unicadata.com.br>. Acesso em 20 jan. 2013.

UNICA. Etanol: Dificuldades e desafios de crescimento. São Paulo. 2011. Disponível em: $<$ www.unica.com.br/download.asp?mmdCode=F60CBD5E-C570-4CC9-8B6199B3F4BCE06A>. Acesso em: 20 jan. 2013.

ÚNICA - União da Indústria de Cana de Açúcar. 2014. Grupos empresariais associados da Única. Disponível em: <http://www.unica.com.br/empresas>. Acesso em: 22 jan 2014.

UNITED STATES. U.S. Department of Agriculture. PSD Online. 2013. Disponível em: $<$ http://www.fas.usda.gov/psdonline/psdQuery.aspx>. Acesso em: 20 dez. 2013.

WOOD, M.B. Marketing Planning: principles into practice. Harlow, Essex: Prentice Hall, 2004.

WORLD TRADE ORGANIZATION. World Commodity Profiles for 2011. Report. Geneva, 2012.

YIN, R.K. Estudos de caso: planejamento e métodos. Tradução Daniel Grassi. 2. ed. Porto Alegre: Bookman, 2001. 205p.

YIN, R.K. Estudos de caso: planejamento e métodos. Tradução Ana Thorell. 4. ed. Porto Alegre: Bookman, 2010. 248p.

ZUIN, L. F. S.; QUEIROZ, T. R. Agronegócios: gestão e inovação. São Paulo: Saraiva, 200 ZYLBERNSZTAJN, D. Estruturas de governança e coordenação do agribusiness: uma aplicação da nova economia das instituições. 238p. Tese (Livre-Docência) - Departamento de Administração, Faculdade de Economia, Administração e Contabilidade, Universidade de São Paulo, São Paulo, 1995.

ZYLBERSZTAJN, D.; FARINA, E. M. M. Q. Dynamics of network governance: a contribution to the study of complex forms. REAd. Revista Eletrônica da Administração. v.16, p. 1-19, 2010.

ZYLBERSZTAJN, D.; NEVES, M. F. (Org.). Economia e gestão dos negócios agrolimentares. São Paulo: Pioneira, 2000. 428p. 


\section{APÊNDICE A: ROTEIRO DE ENTREVISTA (contribuições ao método)}

Este questionário visa avaliar o método de construção do planejamento estratégico utilizado no estado de Goiás e avaliar a aplicabilidade prática dos projetos estruturados. Tais contribuições serão de fundamental importância para a proposição de um método de Planejamento Estratégico para aplicação em estados, que contribuirá para o desenvolvimento do agronegócio nacional.

Fique à vontade para dar quaisquer contribuições que julgar pertinente.

\section{Dados pessoais:}

Nome:

Organização:

Área de atuação:

Desenvolvimento do plano

1. O sr. acredita que o plano estratégico proposto para o estado de Goiás foi elaborado de maneira concisa?

2. As etapas do método seguem uma sequência lógica?

3. Durante a fase de construção do plano estratégico para o estado, o que o sr. acredita que poderia ser feito além das pesquisas, entrevistas e workshops?

4. Como o sr. avalia a contribuição das entrevistas para a estruturação do plano?

5. Como o sr. avalia a contribuição dos workshops para a estruturação do plano?

6. O sr. acredita que que as ferramentas utilizadas no método foram uteis para a construção do plano estratégico para o estado?

7. Existe alguma análise ou ferramenta que o sr. acha pertinente ser incorporado no método a fim de otimizá-lo?

8. Quais são as suas considerações finais acerca do método aplicado no estado de Goiás?

\section{Acompanhamento dos projetos estratégicos}

9. Como está o andamento dos projetos estratégicos propostos ao final do plano?

10. Quais as maiores dificuldades enfrentadas na aplicação dos planos estratégicos no estado?

11. O Sr. acredita que os projetos trarão resultados?

12. O que poderia ser feito para otimizar a aplicação dos projetos estratégicos no estado? 


\section{APÊNDICE B: ROTEIRO DE ENTREVISTA (interlocutores das cadeias)}

Este questionário visa levantar informações específicas acerca das cadeias produtivas do estado de Goiás que contribuam para o estabelecimento do método de gestão estratégica dessas cadeias. Tais informações permitirão identificar desafios e oportunidades para os setores bem como auxiliar na definição de objetivos, metas e ações estratégicas.

As questões do questionário estão divididas em sete áreas: Produção e Produtos; Inovação, Pesquisa e Desenvolvimento; Distribuição e Logística; Capacitação e Qualificação Profissional; Sustentabilidade; Coordenação e Adequação ao Ambiente Institucional; e Comunicação.

\section{Dados pessoais:}

Nome:

Organização:

Área de atuação:

Cadeia produtiva a que fornecerá informações:

\section{Produção e Produtos}

- Qual a atual situação da produção agrícola goiana?

- Como você enxerga o posicionamento da produção e dos produtos goianos no cenário nacional e internacional?

- Quais são os maiores concorrentes do estado de Goiás? Existem novos concorrentes emergindo no cenário nacional e internacional?

- Como você avalia o parque industrial de Goiás? Ele possui vantagens competitivas?

- Existem programas de certificação de produção no estado? Como ele está posicionado frente aos seus concorrentes?

- Goiás é autossuficiente na sua produção?

\section{Inovação, Pesquisa e Desenvolvimento}

- Qual o papel está sendo exercido pelos centros de pesquisa atuantes no estado?

- A tecnologia está presente na produção goiana? Qual o posicionamento do estado na variável tecnológica frente a seus concorrentes?

- Como os centros de pesquisa estão articulados com as organizações privadas (propriedades rurais e indústrias)?

- As principais empresas desenvolvedoras de novas tecnologias (insumos, equipamentos, máquinas etc.) estão presentes no estado?

\section{Distribuição e Logística}

- Quais os principais mercados consumidores do estado de Goiás?

- Quais os modais logísticos mais utilizados e por quê?

- Quais os maiores entraves logísticos para o escoamento da produção goiana?

- Como você acha que a logística do estado poderia ser melhorada?

- Existem centrais logísticas destinadas a pequenos e médios produtores? 


\section{Capacitação e Qualificação Profissional}

- Como você avalia a oferta de mão de obra no estado de Goiás (técnica e gerencial)? É qualificada? A remuneração é compatível com o mercado?

- Existem projetos de qualificação de mão de obra em parcerias com universidades e outras instituições de ensino?

- Qual a taxa de rotatividade do trabalhador no campo? Quais os possíveis motivos para esta taxa?

- Como as organizações privadas buscam contribuir com a qualificação e capacitação de seus trabalhadores?

- Como se dá a integração entre o ensino (treinamentos, cursos, palestras etc.) e a prática?

- Qual a situação do trabalhador goiano frente às leis trabalhistas vigentes?

\section{Sustentabilidade}

- Como o estado é visto quanto à sua sustentabilidade ambiental?

- Existem órgãos ou entidades especificas que tem como objetivo dar suporte a ações de sustentabilidade no estado?

- Qual o grau de adequação das propriedades ao Código Florestal vigente? Quanto isso influencia na competitividade do setor?

- Existe algum tipo de certificação de sustentabilidade no estado?

- Como se dá a ocupação das terras do estado?

\section{Coordenação e Adequação ao Ambiente Institucional}

- Como é a carga tributária do estado? Ela atrai ou repele investimentos?

- Quais as políticas públicas específicas do estado e como está o acesso a elas? E o acesso às políticas públicas federais?

- Existe alguma instituição que presta auxílio jurídico para produtores e indústria?

- Qual o grau de coordenação vertical da cadeia em questão?

- Existem instituições de forte atuação no setor, buscando a união dos elos do mesmo?

\section{Comunicação}

- Como o estado posiciona seu produto no mercado? Existem esforços na busca de diferenciação do produto?

- Existem instituições focadas na execução de ações de marketing para o setor como um todo?

- Quais os esforços da indústria na busca de novos nichos? 
APENDICE C: CRONOGRAMA DE EXECUÇÃO

\begin{tabular}{|c|c|c|c|c|c|c|c|c|c|c|c|c|c|c|c|c|c|c|c|c|c|c|c|c|c|c|c|c|c|c|c|c|c|c|c|}
\hline & & $\bar{\Xi}$ & $\Xi$ & $\vec{\Xi}$ & $\stackrel{1}{\Xi}$ & $\frac{\text { ป }}{2}$ & $\frac{1}{8}$ & $\frac{\mathfrak{t}}{0}$ & $\frac{2}{3}$ & $\frac{7}{8}$ & $\underset{5}{\stackrel{2}{5}}$ & $\underset{\infty}{\stackrel{1}{\infty}}$ & $\frac{7}{8}$ & $\stackrel{1}{3}$ & $\stackrel{\Xi}{\Xi}$ & 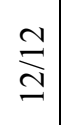 & $\stackrel{m}{\Xi}$ & $\stackrel{m}{\grave{d}}$ & $\frac{m}{\delta}$ & $\stackrel{m}{\frac{m}{\delta}}$ & $\stackrel{m}{\frac{m}{\sigma}}$ & $\frac{m}{8}$ & 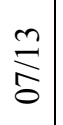 & 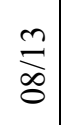 & $\frac{m}{a}$ & $\stackrel{m}{0}$ & $\stackrel{m}{\Xi}$ & 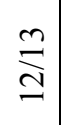 & $\stackrel{ \pm}{\Xi}$ & $\underset{\Delta}{\stackrel{ \pm}{\delta}}$ & $\frac{\vec{\sigma}}{\sigma}$ & $\frac{\vec{t}}{d}$ & $\frac{\pi}{\sqrt[n]{0}}$ & $\frac{\pi}{b}$ & $\frac{\text { t }}{8}$ \\
\hline \multirow{8}{*}{ 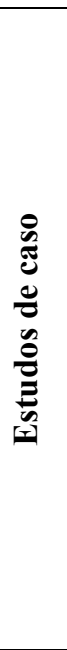 } & $\begin{array}{l}\text { Reuniōes internas } \\
\text { FIEG }\end{array}$ & $\mathrm{X}$ & $\mathrm{X}$ & $\mathrm{X}$ & & & & & & & & & & & & & & & & & & & & & & & & & & & & & & & \\
\hline & $\begin{array}{l}\text { Alinhamento do } \\
\text { projeto }\end{array}$ & & & $\mathrm{X}$ & $\mathrm{X}$ & & & & & & & & & & & & & & & & & & & & & & & & & & & & & & \\
\hline & $\begin{array}{l}\text { Levantamento de } \\
\text { documentos, relatórios } \\
\text { e dados }\end{array}$ & & & & $\mathrm{X}$ & $\mathrm{X}$ & & & & & & & & & & & & & & & & & & & & & & & & & & & & & \\
\hline & $\begin{array}{l}\text { Levantamento de } \\
\text { dados secundários } \\
\text { (mercado, } \\
\text { consumidores, } \\
\text { ambientes, etc) }\end{array}$ & & & & $\mathrm{X}$ & $\mathrm{X}$ & & & & & & & & & & & & & & & & & & & & & & & & & & & & & \\
\hline & $\begin{array}{l}\begin{array}{l}\text { Entrevistas com } 35 \\
\text { interlocutores }\end{array} \\
\text { inters }\end{array}$ & & & & & & $\mathrm{X}$ & & & & & & & & & & & & & & & & & & & & & & & & & & & & \\
\hline & $\begin{array}{l}\text { Proposicião de } \\
\text { posicionamento } \\
\text { estrategico, missão, } \\
\text { visão, etc. }\end{array}$ & & & & & & $\mathrm{X}$ & $\mathrm{X}$ & & & & & & & & & & & & & & & & & & & & & & & & & & & \\
\hline & Workshop de validação & & & & & & & $\mathrm{X}$ & & & & & & & & & & & & & & & & & & & & & & & & & & & \\
\hline & $\begin{array}{l}\text { Revisão final e entrega } \\
\text { dos projetos } \\
\text { estratégicos }\end{array}$ & & & & & & & & $\mathrm{X}$ & $\mathrm{X}$ & & & & & & & & & & & & & & & & & & & & & & & & & \\
\hline \multirow{9}{*}{ 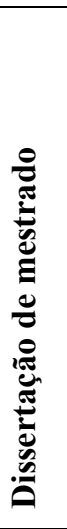 } & $\begin{array}{l}\text { Preparacãõo do } \\
\text { Documento para } \\
\text { Exame de Qualificacãoo }\end{array}$ & & & & & & & $\mathrm{X}$ & $\mathrm{X}$ & $\mathrm{X}$ & $\mathrm{X}$ & $\mathrm{X}$ & $\mathrm{X}$ & $\mathrm{X}$ & $\mathrm{X}$ & $\mathrm{X}$ & $\mathrm{X}$ & $\mathrm{X}$ & $\mathrm{X}$ & $\mathrm{X}$ & $\mathrm{X}$ & $\mathrm{X}$ & & & & & & & & & & & & & \\
\hline & $\begin{array}{l}\text { Depósito do } \\
\text { Documento para } \\
\text { Exame de Qualificação }\end{array}$ & & & & & & & & & & & & & & & & & & & & & $\mathrm{X}$ & & & & & & & & & & & & & \\
\hline & Qualificação & & & & & & & & & & & & & & & & & & & & & & & & $\mathrm{X}$ & & & & & & & & & & \\
\hline & $\begin{array}{l}\text { Finalizaç̃o do } \\
\text { referencial teórico }\end{array}$ & & & & & & & & & & & & & & & & & & & & & & & & $\mathrm{X}$ & $\mathrm{X}$ & $\mathrm{X}$ & $\mathrm{X}$ & $\mathrm{X}$ & $\mathrm{X}$ & & & & & \\
\hline & $\begin{array}{l}\begin{array}{l}\text { Entrevistas para } \\
\text { criticas ao metodo e } \\
\text { contribuiçoes }\end{array} \\
\end{array}$ & & & & & & & & & & & & & & & & & & & & & & & & & & & & & $\mathrm{X}$ & & & & & \\
\hline & Finalização do método & & & & & & & & & & & & & & & & & & & & & & & & & & & & & $\mathrm{X}$ & & & & & \\
\hline & Redação final & & & & & & & & & & & & & & & & & & & & & & & & & & & & & $\mathrm{X}$ & $\mathrm{X}$ & $\mathrm{X}$ & & & \\
\hline & Entrega do relatório & & & & & & & & & & & & & & & & & & & & & & & & & & & & & & & & $\mathrm{X}$ & & \\
\hline & Defesa da Dissertação & & & & & & & & & & & & & & & & & & & & & & & & & & & & & & & & & $\mathrm{X}$ & \\
\hline
\end{tabular}

